\section{Pacific Northwest} National Laboratory

Operated by Battelle for the U.S. Tepartment of Energy

\title{
In Situ Gaseous Reduction Pilot Demonstration - Final Report
}

\author{
E. C. Thornton \\ K. B. Olsen \\ J. T. Giblin \\ J. M. Phelan \\ T. J Gilmore \\ R. D. Miller
}

February 1999

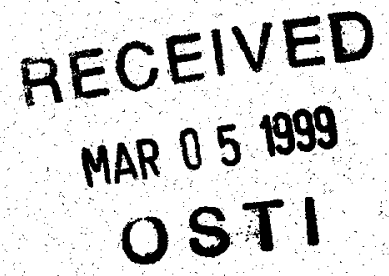

Prepared for the U.S. Department of Energy under Contract DE-AC06-76RLO 1830 


\title{
DISCLAIMER
}

This report was prepared as an account of work sponsored by an agency of the United States Government. Neither the United States Government nor any agency thereof, nor Battelle Memorial Institute, nor any of their employees, makes any warranty, express or implied, or assumes any legal liability or responsibility for the accuracy, completeness, or usefulness of any information, apparatus, product, or process disclosed, or represents that its use would not infringe privately owned rights. Reference herein to any specific commercial product, process, or service by trade name, trademark, manufacturer, or otherwise does not necessarily constitute or imply its endorsement recommendation, or favoring by the United States Government or any agency thereof, or Battelle Memorial Institute. The views and opinions of authors expressed herein do not necessarily state or reflect those of the United States Government or any agency thereof.

\author{
PACIFIC NORTHWEST NATIONAL LABORATORY \\ operated by \\ BATTELLE \\ for the \\ UNITED STATES DEPARTMENT OF ENERGY \\ under Contract $D E-A C 06-76 R L O 1830$
}

Printed in the United States of America

- Available to DOE and DOE contractors from the

Office of Scientific and Technical Information, P.O. Box 62, Oak Ridge, TN 37831;

prices available from (615) $576-8401$.

Available to the public from the National Technical Information Service, U.S. Department of Commerce, 5285 Port Royal Rd., Springfield, VA 22161 


\section{In Situ Gaseous Reduction Pilot Demonstration - Final Report}
E. C. Thornton
K. B. Olsen
J. T. Giblin ${ }^{(a)}$
J. M. Phelan ${ }^{(b)}$
T. J Gilmore
R. D. Miller ${ }^{(\mathrm{c})}$

February 1999

Prepared for
the U.S. Department of Energy
under Contract DE-AC06-76RLO 1830

This work is funded by the Office of Science and Technology, within the U.S. Department of Energy's Office of Environmental Management, under the Subsurface Contaminants Focus Area

Pacific Northwest National Laboratory Richland, Washington 99352

\footnotetext{
(a) MEVATEC Corporation, White Sands Missile Range, New Mexico

(b) Sandia National Laboratories, Albuquerque, New Mexico

(c) Professional Analysis Incorporated, Richland, Washington
} 



\section{Executive Summary}

Laboratory investigations conducted over the last several years indicated that chromate-contaminated soils can potentially be remediated through treatment with a diluted hydrogen sulfide $\left(\mathrm{H}_{2} \mathrm{~S}\right)$ mixture. To test this approach, a field demonstration was conducted at the White Sands Missile Range in a cooperative effort between the U.S. Department of Energy and the U.S. Department of Defense. In this test, in situ treatment by gaseous reduction was undertaken by injecting $200 \mathrm{ppm}_{\mathrm{v}} \mathrm{H}_{2} \mathrm{~S}$ into chromate-contaminated soils. Presented in this report are data collected during the demonstration that verify the effectiveness of the approach, illustrate the approach can be applied in a safe and environmentally acceptable manner, and provide information to evaluate the cost of in situ gaseous reduction relative to the baseline remediation approach.

A series of activities were undertaken during fiscal years (FYs) 1996 through 1998 that culminated in the injection phase of the demonstration, including pretreatment site characterization and performance of a laboratory treatability study (FY 1996). Information collected during pretreatment characterization included concentrations and distribution of hexavalent chromium (Cr[VI]) and selected redox parameters. A vacuum test was also conducted with the injection borehole as a means of providing information regarding airflow characteristics through the site. The treatability test was conducted with contaminated soil from the site. In these tests, $\mathrm{Cr}(\mathrm{VI})$ was reduced by $98 \%$ by treatment with $100-\mathrm{ppm}_{\mathrm{v}} \mathrm{H}_{2} \mathrm{~S}$ after application of a ratio of $0.00004 \mathrm{lb}$ of $\mathrm{H}_{2} \mathrm{~S}$ /pound of soil. The characterization and treatability test data were utilized to design the well-field network and provided a basis for estimating the treatment time required.

Following installation of the well-field network, a tracer test was conducted in late FY 1997 wherein a $400-\mathrm{ppm}_{\mathrm{v}}$ mixture of sulfur hexafluoride $\left(\mathrm{SF}_{6}\right.$; the tracer) was injected via a skid-mounted gas-treatment system. Test results provided gas-flow rates and indicated good gas-capture characteristics. Satisfactory operation of the system was verified during the tracer test.

Activities conducted during FY 1998 culminated in the injection phase of the demonstration, including preparation of work and safety plans, completion of field site preparation activities, and determination of state and site operating requirements. The gas-treatment-injection test was performed between midApril through June 1998. The data and conclusions regarding operation of the system, well-field equipment, and environmental monitoring and alarm system are included in this report. All systems performed in a satisfactory manner, and no significant releases of $\mathrm{H}_{2} \mathrm{~S}$ to the atmosphere occurred. Also accomplished was collection of posttreatment soil-characterization samples during July 1998.

Final performance assessment of the demonstration is presented herein based on the analysis of the posttreatment characterization samples for $\mathrm{Cr}(\mathrm{VI})$ and comparison of the results to the pretreatment data. This information indicates that $70 \%$ of the $\mathrm{Cr}(\mathrm{VI})$ was reduced. In particular, the zone of highest $\mathrm{Cr}(\mathrm{VI})$ concentration, located at a depth of 4 to $10 \mathrm{ft}$, was nearly completely treated, with $\mathrm{Cr}$ (VI) concentrations of soil samples decreasing from an average of $8.1 \mathrm{mg} / \mathrm{kg}$ before treatment to $1.14 \mathrm{mg} / \mathrm{kg}$ after treatment. However, a zone of lower contamination (from 10 to $16 \mathrm{ft}$ ) was largely unaffected. It is concluded that the treatment gas mixture was largely channeled through the upper zone and bypassed the less-permeable, lower zone. Treatment of the lower zone could probably be completed, if necessary, through injection of gas into the zone through a borehole specifically screened over this interval. 



\section{Acknowledgments}

This work was prepared with the support of the following contributors:

Headquarters:

Focus Area/Program:

Operations Office:

Contractor:
Office of Science and Technology

G. "Skip" Chamberlain, Jr.

Subsurface Contaminants Focus Area

James A. Wright

Richland Operations Office

Science and Technology Programs Division

John P. Neath, Technical Program Officer

Pacific Northwest National Laboratory

Environmental Science and Technology

Environmental Technology Division

Steven L. Stein, Manager

The authors wish to acknowledge the contributions of a number of individuals who participated in or supported the in situ gaseous reduction pilot demonstration: Ron Schalla, George Last, Heidi Hampt, Janet Julya, Mary Peterson, Joe Devary, John Fruchter, Wayne Martin, Rick Cameron, and Mike Fullmer of Pacific Northwest National Laboratory; Dianne Marozas and other Sandia National Laboratories' staff; Mark Duchsherer of COGEMA Engineering Corporation; Keith Larkin of Babcock and Wilcox Hanford Company; Mike Hogan of MSE Technology Applications; Hector Magallanes and Lionel Brown of White Sands Missile Range; and staff of the MEVATEC Corporation. 



\section{Contents}

Executive Summary …….................................................................................................... iii

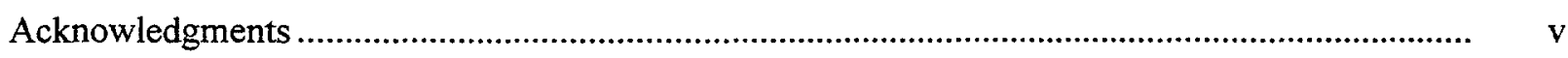

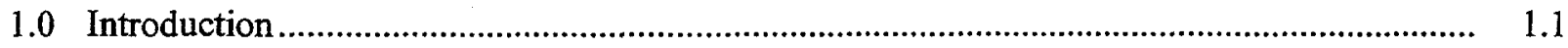

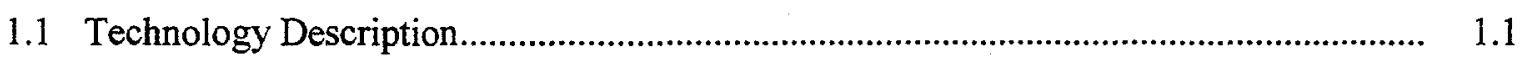

1.2 Demonstration Approach and Objectives .................................................................... 1.1

1.3 Notes on Units of Measure ……….......................................................................

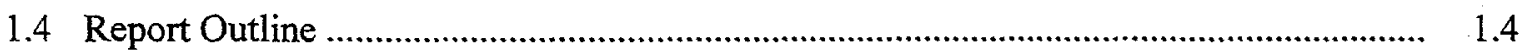

2.0 Gas-Treatment System and Well-Field Design................................................................... 2.1

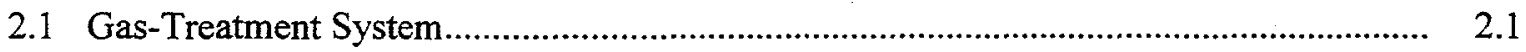

2.2 Well-Field Network Design ................................................................................... 2.4

3.0 Test Site Description and History ............................................................................... 3.1

3.1 Regional Geology ................................................................................................

3.2 History of Contamination ........................................................................................

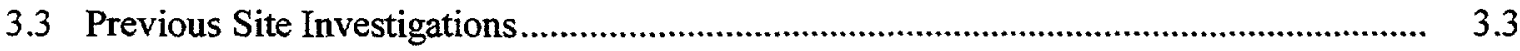

3.4 Local Hydrogeologic Setting ..................................................................................... 3.4

4.0 Pretreatment Site Characterization and Well-Field Installation................................................ 4.1

4.1 Site Geologic Investigation...................................................................................

4.2 Site Chemical and Geotechnical Characteristics …………......................................... 4.5

4.2.1 Soil-Moisture Content ..................................................................................... 4.5

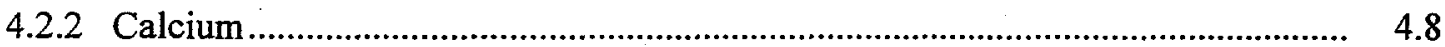

4.2.3 Chromium, Iron, and Organic Carbon ............................................................... 4.8

4.3 Air Permeability Test................................................................................................. 4.12 
5.0 Laboratory Treatability Study ...........................................................................................

5.1 Column Gas-Treatment Procedure and Breakthrough Characteristics ........................... 5.1

5.2 Column Leach Procedure and Analysis of Leachate Solutions .................................... 5.2

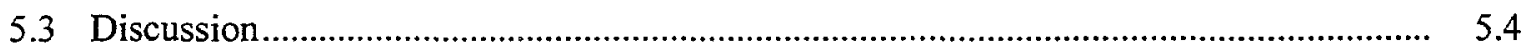

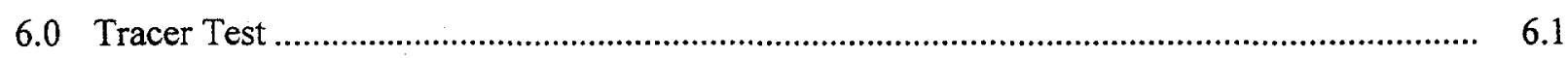

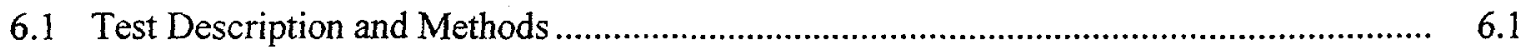

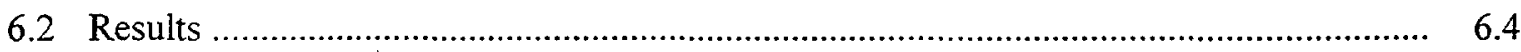

6.2.1 Gas-Treatment System Performance .......................................................... 6.4

6.2.2 Well-Field Pressure and Flow-Rate Data ......................................................... 6.4

6.2.3 Monitoring of Well-Field and Background Gas Concentrations .......................... 6.7

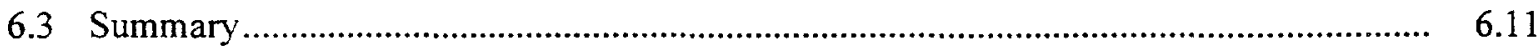

7.0 Gas-Treatment Injection Test.....................................................................................

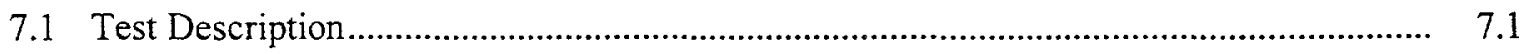

7.2 Environmental Monitoring and Alarm System .................................................... 7.2

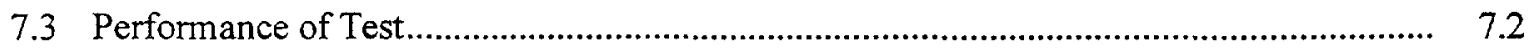

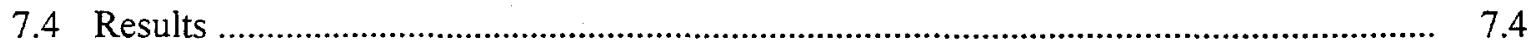

7.4.1 Treatment System Performance .................................................................... $\quad 7.4$

7.4.2 Well-Field Pressures and Flow Rates ............................................................. 7.4

7.4.3 Well-Field Treatment Gas Concentrations and Breakthrough Monitoring ............ 7.14

7.4.4 Environmental Monitoring and Alarm System Performance ............................... 7.17

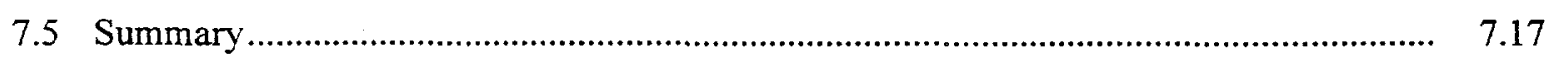

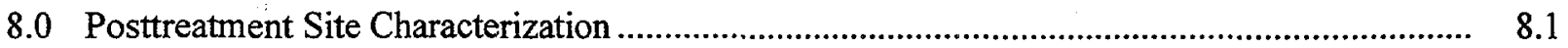

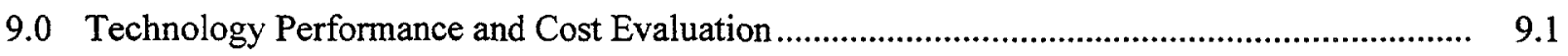

9.1 Technical Performance Evaluation ....................................................................... 9.1

9.1.1 Hexavalent Chromium Mass Reduction Calculation............................................ 9.1

9.1.2 Consumption of Hydrogen Sulfide During Soil Treatment Demonstration ........... 9.7 


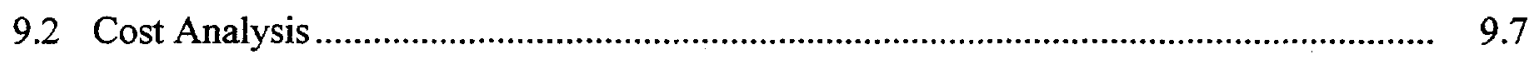

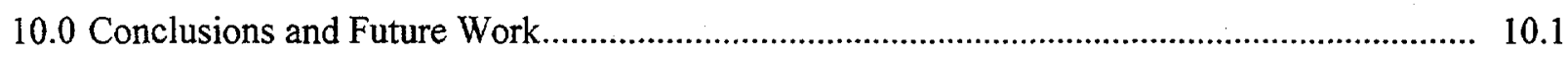

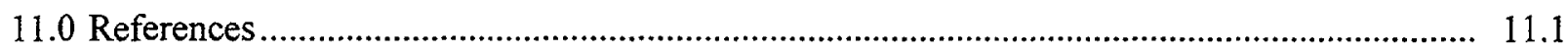




\section{Figures}

1.1 Gas-Treatment System and Cross Section of Well-Field Network ..................................... 1.2

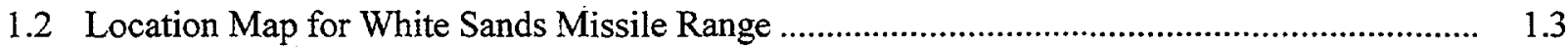

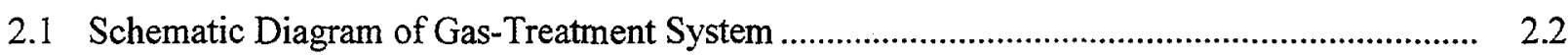

2.2 Perspective View of Gas-Treatment System ...................................................................... 2.3

2.3 Well-Field Network Pressure Gauges, Flow Meters, and Gas-Sampling Points .................... 2.5

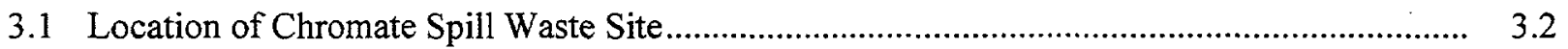

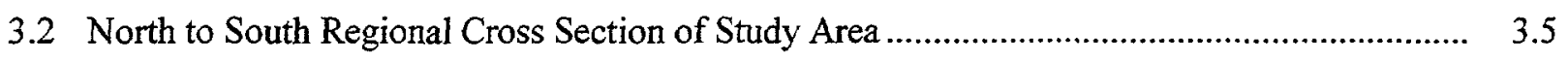

4.1 Configuration of Well-Field Network, Soil-Gas Points, and Soil-Sampling

Locations.

4.2 Generalized Stratigraphic Section for Chromate Spill Waste Site .................................... 4.4

4.3 Depth Profile for Pretest Soil-Moisture Content ...........................................................

4.4 Depth Profile for Average Calcium Concentration ...................................................... 4.9

4.5 Depth Profiles for Average Pretest Soil Hexavalent Chromium and Total Chromium Concentrations ...

4.6 Depth Profiles for Average Iron Pretest Soil Concentrations ......................................... 4.11

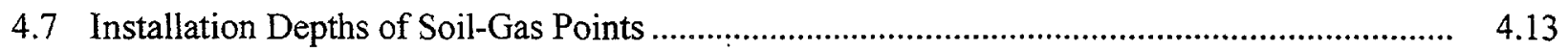

4.8 Variation of Soil-Gas Point Vacuum Pressures with Radial Distance from IGRS-1 f............. 4.15

5.1 Hydrogen Sulfide Breakthrough Curve for Test GP5-14-2 …........................................ 5.2

5.2 Hydrogen Sulfide Breakthrough Curve for Test GP5-14-3 ........................................... 5.2

5.3 Hexavalent Chromium Concentrations of Column Leachate Samples for

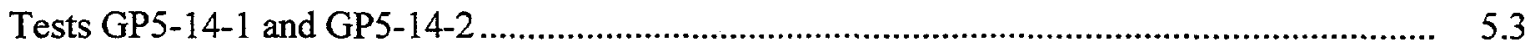

5.4 Hexavalent Chromium Concentrations of Column Leachate Samples for Tests GP5-14-1 and GP5-14-3 
6.1 Tracer Test Site Map and Gas-Sampling Locations.........................................................

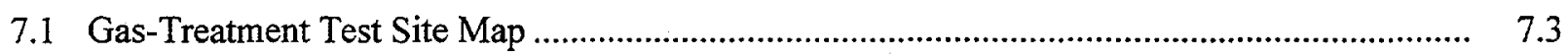

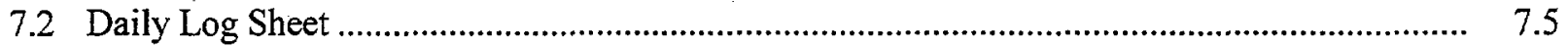

7.3 Injection Pressure and Flow-Rate Data and Sum of Extraction Well Flow Rates ................... 7.10

7.4 Differential Pressures Measured for Extraction Wells ......................................................... 7.12

7.5 Differential Pressures Measured at Soil-Gas-Sampling Points ............................................ 7.13

8.1 Depth Profiles of Soil-Moisture Contents for Pre- and Posttest Soil Samples ........................ $\quad 8.4$

9.1 Distribution of Hexavalent Chromium Prior and Subsequent to Gas Treatment.................... 9.3

9.2 Mass of Hexavalent Chromium Versus Depth Before and After Gas Treatment .................... $\quad 9.6$

\section{Tables}

4.1 Pretest Geochemical Data from GP-Series Core Samples from Chromate Spill Waste Site

4.2 Pretest Geochemical Data from IGRS-1 and M-Series Core Samples from Chromate Spill Waste Site.

4.3 Air Permeability Test Data..

4.4 Permeability Estimates Based on Test Measurements

6.1 Tracer Test Well-Field Pressure and Flow-Rate Data .................................................. 6.5

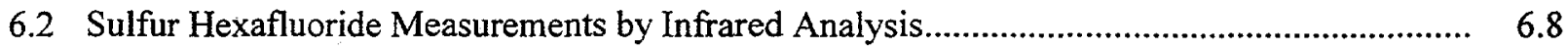

6.3 Sulfur Hexafluoride Measurements by Gas Chromatograph/Flame Photometric Detector...... $\quad 6.9$

6.4 Sulfur Hexafluoride Measurements by Gas Chromatograph/Electron Capture Detector .......... $\quad 6.10$

7.1 Gas-Treatment Test Well-Field Flow Rates and Pressures.......................................... 
7.2 Soil-Sampling Point Pressures

7.3 Well-Field Hydrogen Sulfide Concentrations.

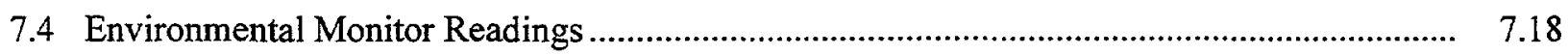

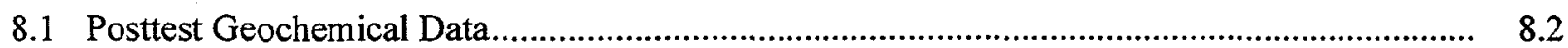

9.1 Hexavalent Chromium Data used to Calculate Total Mass Present in Site Soils Before Test.

9.2 Hexavalent Chromium Data used to Calculate Total Mass Present in Site Soils After Test

9.3 Mass Calculations of Hexavalent Chromium Before and After Gas Injection

9.2 


\subsection{Introduction}

Laboratory and field activities are supported by the U.S. Department of Energy to evaluate the use of a reducing gas mixture (diluted hydrogen sulfide $\left[\mathrm{H}_{2} \mathrm{~S}\right]$ ) for the in situ treatment of soils contaminated with hexavalent chromium (Cr[VI]). Presented herein is a summary of activities undertaken during the performance of the in situ gaseous reduction system (IGRS) test, which was conducted as a collaborative effort between Pacific Northwest National Laboratory, ${ }^{1}$ Sandia National Laboratories, White Sands Missile Range, and the MEVATEC Corporation.

\subsection{Technology Description}

It is proposed that the application of diluted $\mathrm{H}_{2} \mathrm{~S}$ to chromium $(\mathrm{Cr})$ reduction in the field be accomplished through the injection of the gas mixture into waste site soils in a central borehole (Figure 1.1). The gas mixture could then be drawn through the waste site by vacuum applied at extraction boreholes located at the site boundary. Monitoring of $\mathrm{H}_{2} \mathrm{~S}$ breakthrough at the extraction wells would thus provide a basis for assessing treatment progress. Verification of treatment effectiveness could subsequently be accomplished through a comparison of $\mathrm{Cr}$ (VI) distribution through site soils before and after treatment.

Laboratory tests have been completed that indicate $90 \%$ or better reduction and immobilization of $\mathrm{Cr}$ can potentially be achieved by this approach (Thornton and Jackson 1994, Thornton and Amonette 1997). The primary chemical reaction of interest associated with these tests involves the reduction of $\mathrm{Cr}(\mathrm{VI})$ to $\mathrm{Cr}(\mathrm{III})$. The contaminant will subsequently precipitate as an oxyhydroxide solid phase. The reduction and immobilization of $\mathrm{Cr}(\mathrm{VI})$ may be represented by the following generalized reaction:

$$
8 \mathrm{CrO}_{4}{ }^{2-}+3 \mathrm{H}_{2} \mathrm{~S}+10 \mathrm{H}^{+}+4 \mathrm{H}_{2} \mathrm{O} \rightarrow 8 \mathrm{Cr}(\mathrm{OH})_{3}+3 \mathrm{SO}_{4}{ }^{2-} \text {. }
$$

Note that $\mathrm{H}_{2} \mathrm{~S}$ is converted to $\mathrm{SO}_{4}{ }^{2-}$ in this reaction and that 3 moles of $\mathrm{H}_{2} \mathrm{~S}$ are required to reduce 8 moles of $\mathrm{Cr}(\mathrm{VI})$ to $\mathrm{Cr}(\mathrm{III})$. The products of this reaction include minor amounts of $\mathrm{SO}_{4}{ }^{2-}$, which is not generally regarded as a contaminant of concern, and $\mathrm{Cr}(\mathrm{III})(\mathrm{OH})_{3}$, an insoluble and essentially nontoxic solid.

\subsection{Demonstration Approach and Objectives}

A chromate $\left(\mathrm{CrO}_{4}{ }^{2-}\right)$-contaminated site was selected in fiscal year 1996 for the initial demonstration of the IGRS technology. This waste site is located at the High-Energy Laser System Test Facility, which is a subarea of the U.S. Department of Defense White Sands Missile Range, New Mexico (Figure 1.2).

The primary objectives of undertaking the demonstration were to provide technical and cost performance information needed to assess the viability of the approach and to obtain operational information

\footnotetext{
${ }^{1}$ Pacific Northwest National Laboratory is operated by Battelle for the U.S. Department of Energy.
} 


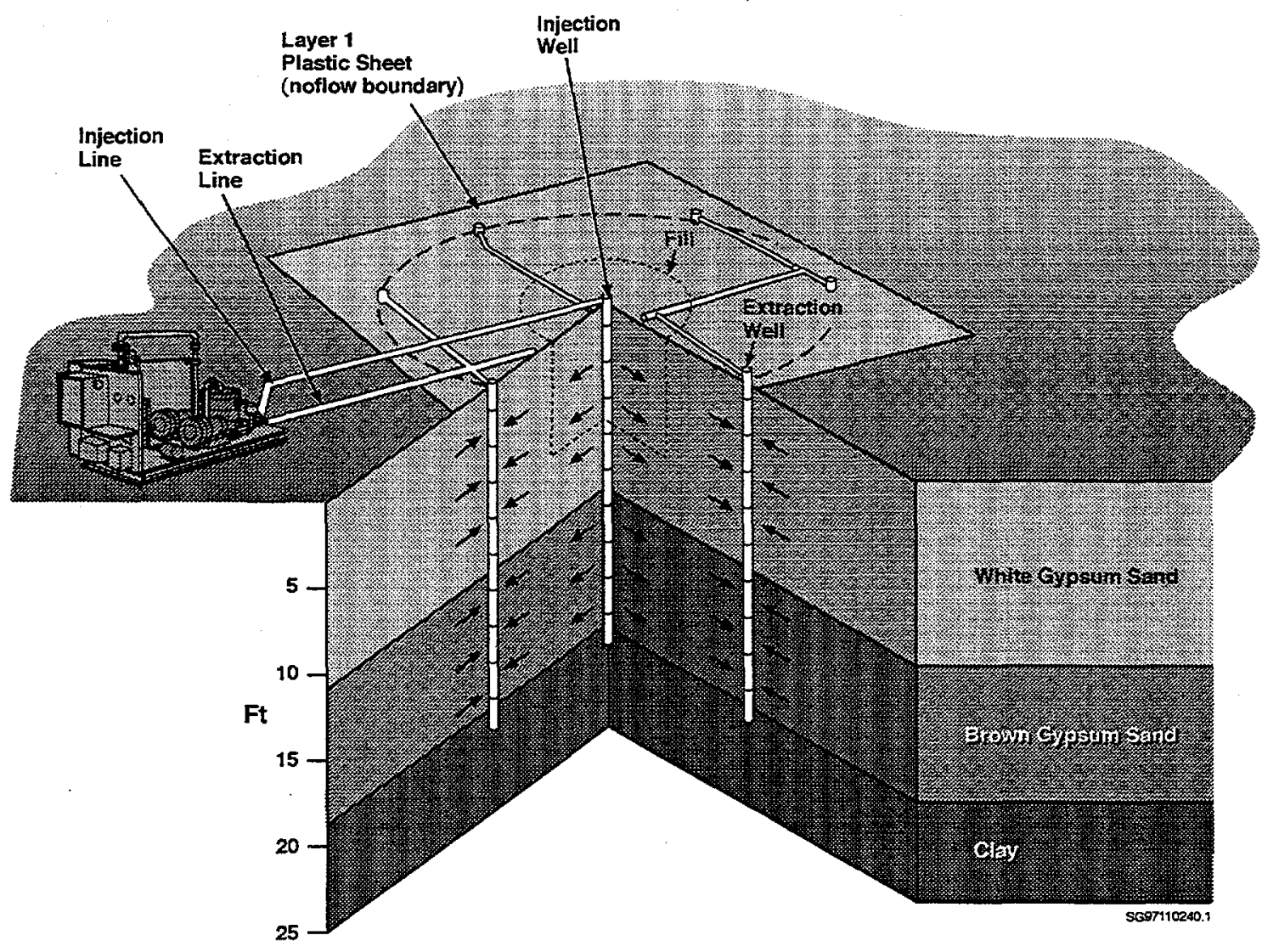

Figure 1.1. Gas-Treatment System and Cross Section of Well-Field Network

needed to verify that the approach can be utilized in a safe and environmentally acceptable manner. A series of activities were performed during the course of the demonstration to accomplish these objectives. Initial work involved collecting soil samples from the site for analysis and characterization. In particular, the samples were analyzed for $\mathrm{Cr}(\mathrm{VI})$ to provide a model of contaminant distribution at the site. This model provided a basis for placement of the injection and extraction boreholes. In addition, soil samples were utilized in a laboratory treatability study to provide information regarding treatment effectiveness. A field gas tracer test was subsequently undertaken to provide information regarding site airflow characteristics.

The injection test was initiated in mid-April and continued through June 1998. During the test, information was collected related to the gas-treatment and well-field systems. In particular, the monitoring of $\mathrm{H}_{2} \mathrm{~S}$ breakthrough in the extraction wells was utilized as a means of assessing treatment progress during the test. In addition, an environmental monitoring system was installed to detect any releases of $\mathrm{H}_{2} \mathrm{~S}$ to the atmosphere. Subsequent to completion of the gas-treatment test, soil samples were collected from the site in July 1998 and submitted to a contract laboratory for $\mathrm{Cr}(\mathrm{VI})$ analysis. The results of the soil analysis are presented in this report and are utilized to complete a performance assessment of the technology. 


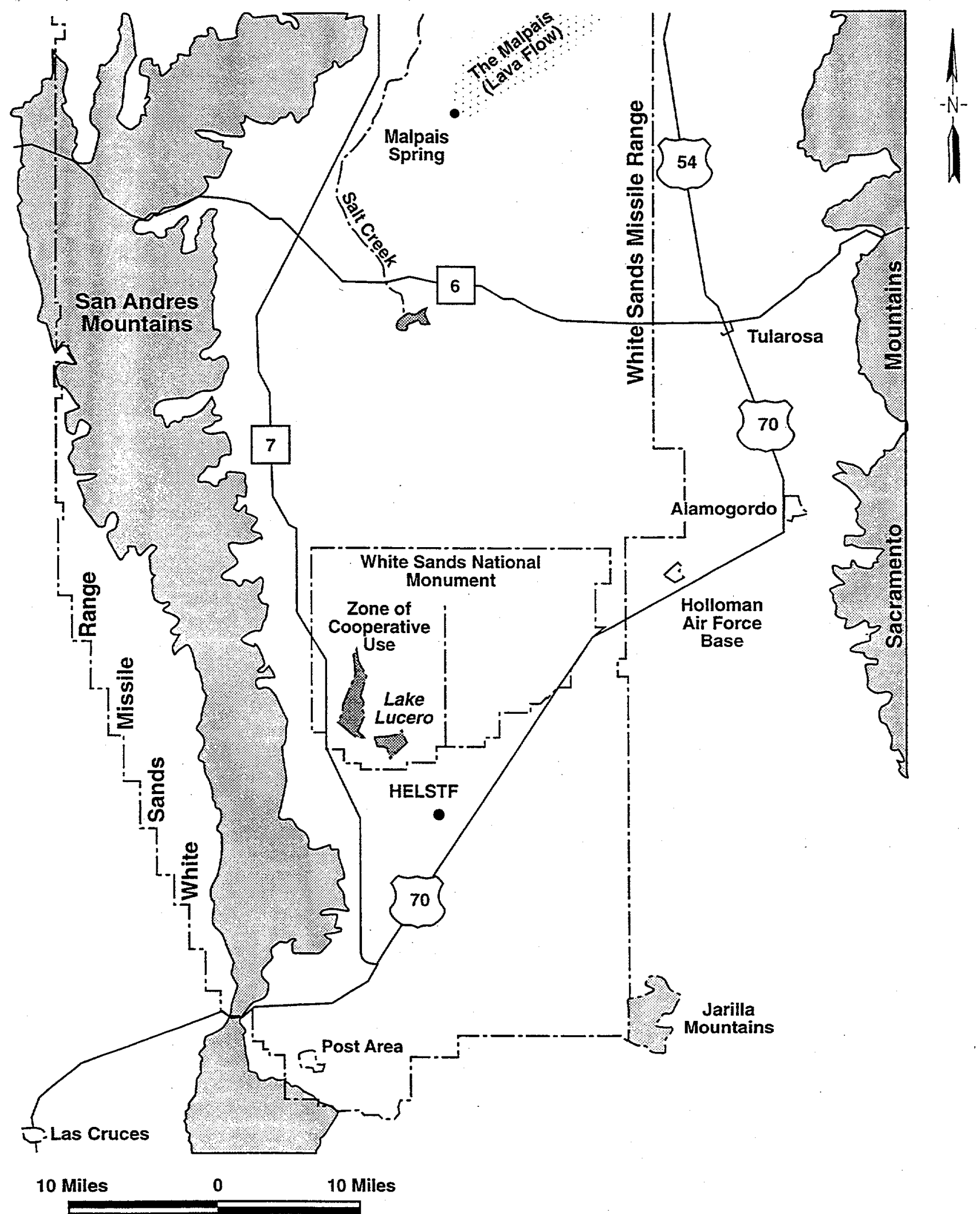

RG98120160.2

Figure 1.2. Location Map for White Sands Missile Range 


\subsection{Notes on Units of Measure}

This report uses English units because most historical information concerning the drilling and logging of boreholes is in English units, and most users of borehole data are familiar with parameters such as casing diameter in English units. However, the results of laboratory tests and analyses of constituents are reported in metric units.

\subsection{Report Outline}

A description of the gas-treatment system and the well-field network design is given in Section 2.0. A description and history of the test site are provided in Section 3.0. Pretreatment site characterization and well-field installation are presented in Section 4.0. The results of a laboratory treatability study are presented in Section 5.0. The results of a tracer test are provided in Section 6.0. Setup and results of the gas-treatment test are presented in Section 7.0. Posttreatment characterization results are presented in Section 8.0. Section 9.0 provides a summary of the technology performance and cost evaluation. The conclusions regarding treatment effectiveness are given in Section 10.0, followed by the references cited in the text (Section 11.0). 


\subsection{Gas-Treatment System and Well-Field Design}

The two major components of the IGRS approach are the gas-treatment system and the well-field network (see Figure 1.1). The basic designs of these two systems are presented in this section.

\subsection{Gas-Treatment System}

The purpose of the gas-treatment system is to prepare the diluted gas mixture and to provide enough pressure for the injection of the mixture into the soil to be treated. The system also withdraws air from the well field by application of a vacuum and removes residual treatment gas from this stream before release of the air to the site atmosphere.

The skid-mounted, prototype, gas-treatment system was originally designed and fabricated by the Westinghouse Hanford Company under contract to the U.S. Department of Energy (Larkin 1995). The system is equipped with an injection pump, extraction pump, water knockout tank, and scrubber (Figures 2.1 and 2.2).

The injection pump is a Model DR 823, EG\&G Rotron Regenerative Blower. This unit has the potential to provide a maximum (no-load) airflow rate of $5.2 \mathrm{~m}^{3} / \mathrm{min}\left(184 \mathrm{ft}^{3} / \mathrm{min}\right.$ ). $\mathrm{H}_{2} \mathrm{~S}$ is introduced into the air stream immediately after exiting the injection pump and is supplied from a commercial gas cylinder housed in a gas-storage cabinet. $\mathrm{H}_{2} \mathrm{~S}$ is controlled by a regulator and flow meter and is automatically shut off by a solenoid valve in the event of a power failure.

The extraction pump is a Model CP 808, EG\&G Rotron Regenerative Blower. This model is designed for use with $\mathrm{H}_{2} \mathrm{~S}$ gas streams, is surface treated or plated, and has gas-tight seals. The blower is rated to draw an air stream under vacuum at a maximum (no-load) flow rate of $9.8 \mathrm{~m}^{3} / \mathrm{min}\left(345 \mathrm{ft}^{3} / \mathrm{min}\right)$. The air stream is extracted from the well field and pulled through a water knockout tank by the extraction blower and then passed through a scrubber. A granular activated carbon canister can be added to the system if volatile organic compounds are present in the extracted gas stream.

The water knockout tank is located on the vacuum side of the extraction pump and serves to remove debris and moisture from the extraction air stream. The scrubber is positioned on the positive pressure side of the extraction pump; its function is to remove the unreacted $\mathrm{H}_{2} \mathrm{~S}$ gas from the air stream prior to discharge. The scrubber contains $57 \mathrm{~L}$ ( $15 \mathrm{gal}$ ) of a caustic solution (e.g., $1 \mathrm{molar} \mathrm{NaOH}$ ) recirculated through the scrubber at a rate of $\sim 7.6 \mathrm{~L} / \mathrm{min}(2 \mathrm{gal} / \mathrm{min}$ ). The scrubber solution $\mathrm{pH}$ is monitored and replaced when the $\mathrm{pH}$ drops below 10 . This serves to ensure efficient $\mathrm{H}_{2} \mathrm{~S}$ removal before discharge of the extraction air stream. The scrubber exhaust stack is also equipped with an $\mathrm{H}_{2} \mathrm{~S}$ sensor to monitor the discharged air stream. 


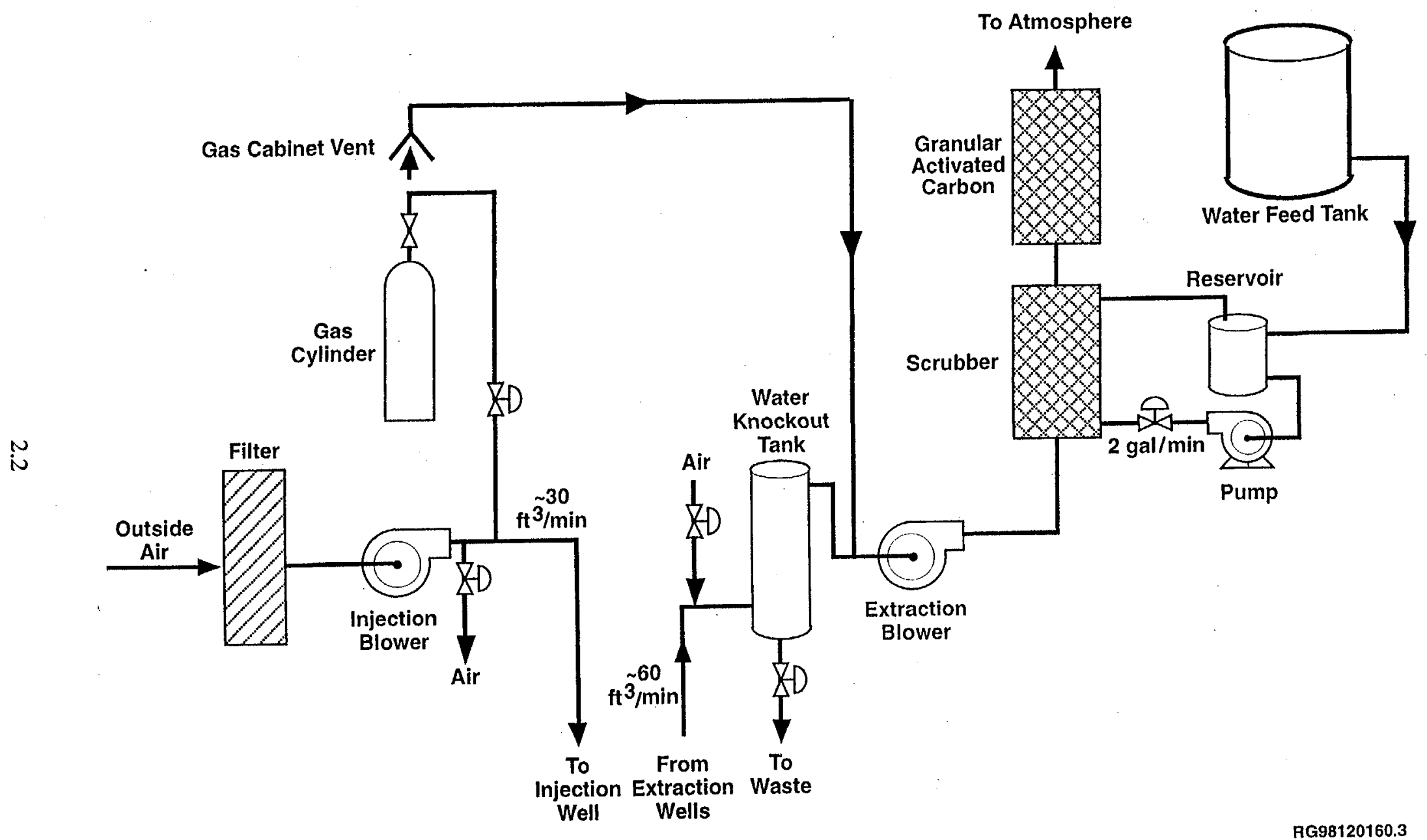

Figure 2.1. Schematic Diagram of Gas-Treatment System 


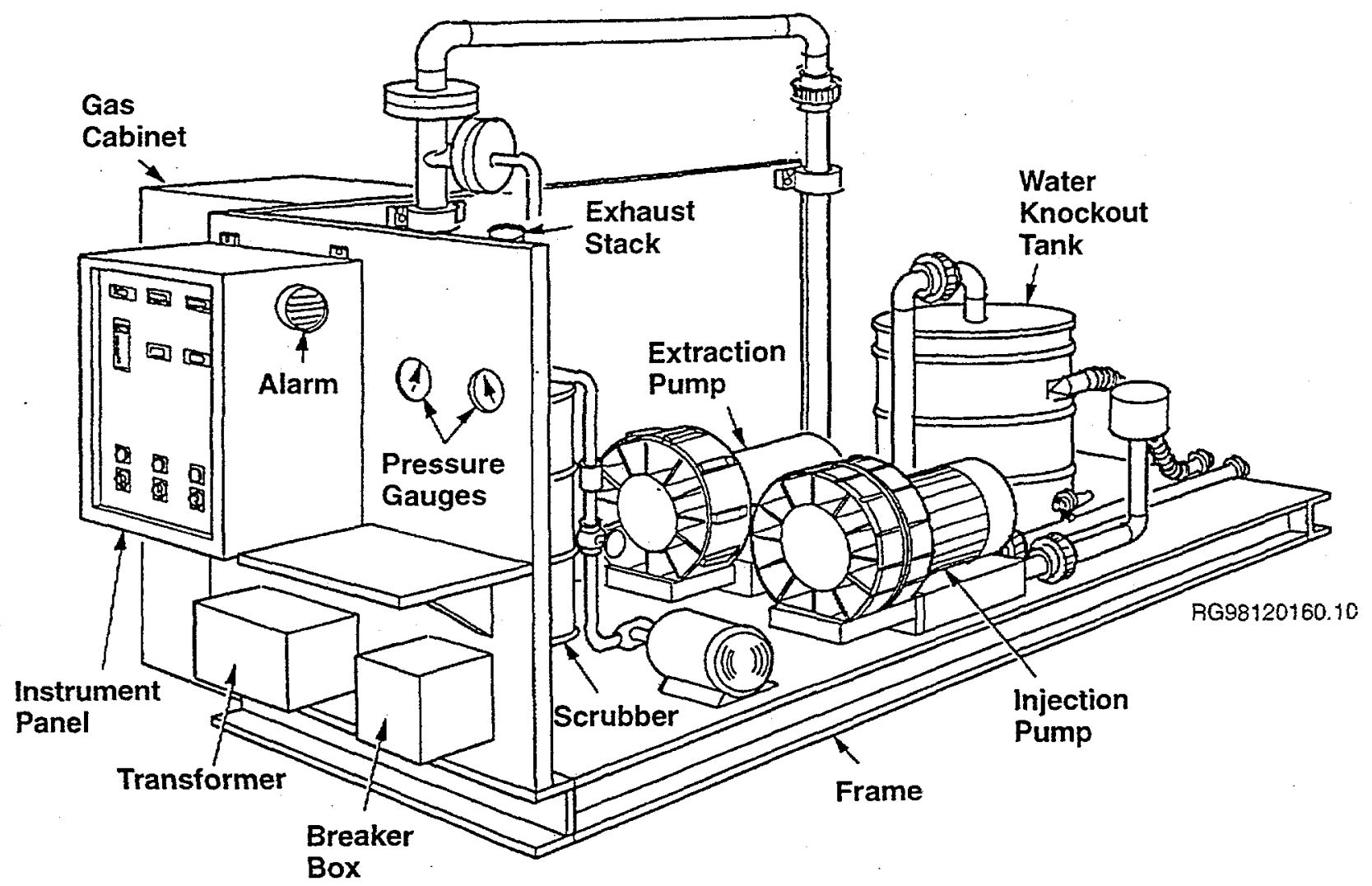

Figure 2.2. Perspective View of Gas-Treatment System

The gas-treatment system operates on $480-\mathrm{V}, 60$-amp line power. A portable generator can be employed in the field if line power is not available or can be used as backup power in the event of a site power failure.

An acceptance test plan was prepared for the purpose of verifying that the prototype operates as designed (Larkin 1995). The preliminary tests outlined in the plan were satisfactorily completed. The following interlocks/safety systems have been configured into the system and were checked during the acceptance test and determined to be functional.

- The injection pump will not operate without the extraction pump already in operation.

- A fluid-level switch within the water knockout tank, when activated, will shut down the extraction and injection pumps and stop the flow of injection gas.

- An $\mathrm{H}_{2} \mathrm{~S}$ monitor high-level alarm will shut down the injection and extraction pumps, stop the flow of injection gas, and sound an alarm. 
The gas-treatment system underwent additional operational testing activities in fiscal year 1996, including performance evaluation of the $\mathrm{H}_{2} \mathrm{~S}$ scrubber. ${ }^{1}$ An operations manual was also prepared. ${ }^{2}$

Several system modifications were incorporated during field-testing activities. Air-bleed valves were added downstream of the injection blower and upstream of the extraction blower during the tracer test (see Figure 2.1). This was necessary to balance airflow and prevent overworking the blowers. Prior to the gas-treatment test, a water-feed tank was also added to the gas-treatment system. This was needed to supply water lost from the scrubber by evaporation in the exhaust air stream. The required water-feed rate under operating conditions is $\sim 3.8 \mathrm{~L} / \mathrm{h}(1 \mathrm{gal} / \mathrm{h}$ ) based on evaporation rates observed in laboratory and field tests. The gas cabinet was also equipped with a vent, as shown in Figure 2.1. This was incorporated into the system as a safety feature and provides a means of capturing any release of $\mathrm{H}_{2} \mathrm{~S}$ within the gas cabinet by directing it toward the scrubber for removal.

\subsection{Well-Field Network Design}

The basic design consists of a central injection borehole and six extraction wells situated in a hexagonal pattern around the injection well (see Figure 1.1). A diluted mixture of $\mathrm{H}_{2} \mathrm{~S}$ in air is prepared by the gas-treatment system and introduced into the site soil by pressure injection through the central borehole. The gas mixture is then drawn radially outward through the site via the vacuum applied to the extraction wells located at the edge of the waste site.

To increase treatment efficiency, the injection and extraction boreholes were slotted over the contaminated interval to restrict gas flow to that interval. An impermeable cover was also placed over the site to minimize escape of the treatment gas and to maximize horizontal flow through the target interval. The edges of the cover should be secured at the edges and sealed at the contacts with the well casings to minimize airflow across the cover.

A detailed configuration of the treatment system and well field is presented in Figure 2.3, along with pressure gauges, flow meters, and gas-sampling ports associated with the well-field boreholes. Also shown are the locations of soil-gas points that can be used to obtain additional pressure data and gas samples. Monitoring of well-field pressures and flow rates provides a means of assessing gas-flow patterns, while chemical sensors are utilized to measure $\mathrm{H}_{2} \mathrm{~S}$ concentrations of well-field gas samples. Breakthrough of $\mathrm{H}_{2} \mathrm{~S}$ at the extraction wells provides a means of gauging treatment progress. Adjustment of treatment gas flow through the site can be controlled by extraction well-flow valves, thus permitting uniform treatment of the site by directing the movement of the chemical reaction front.

\footnotetext{
${ }^{1}$ M. Duchsherer. 1996. Hydrogen sulfide scrubber performance test report. Internal Memo 8A400-96023, Westinghouse Hanford Company, Richland, Washington.

${ }^{2} \mathrm{M}$. Duchsherer. 1996. In-situ $H_{2} S$ vapor injection/extraction skid operation manual. Westinghouse Hanford Company, Richland, Washington.
} 


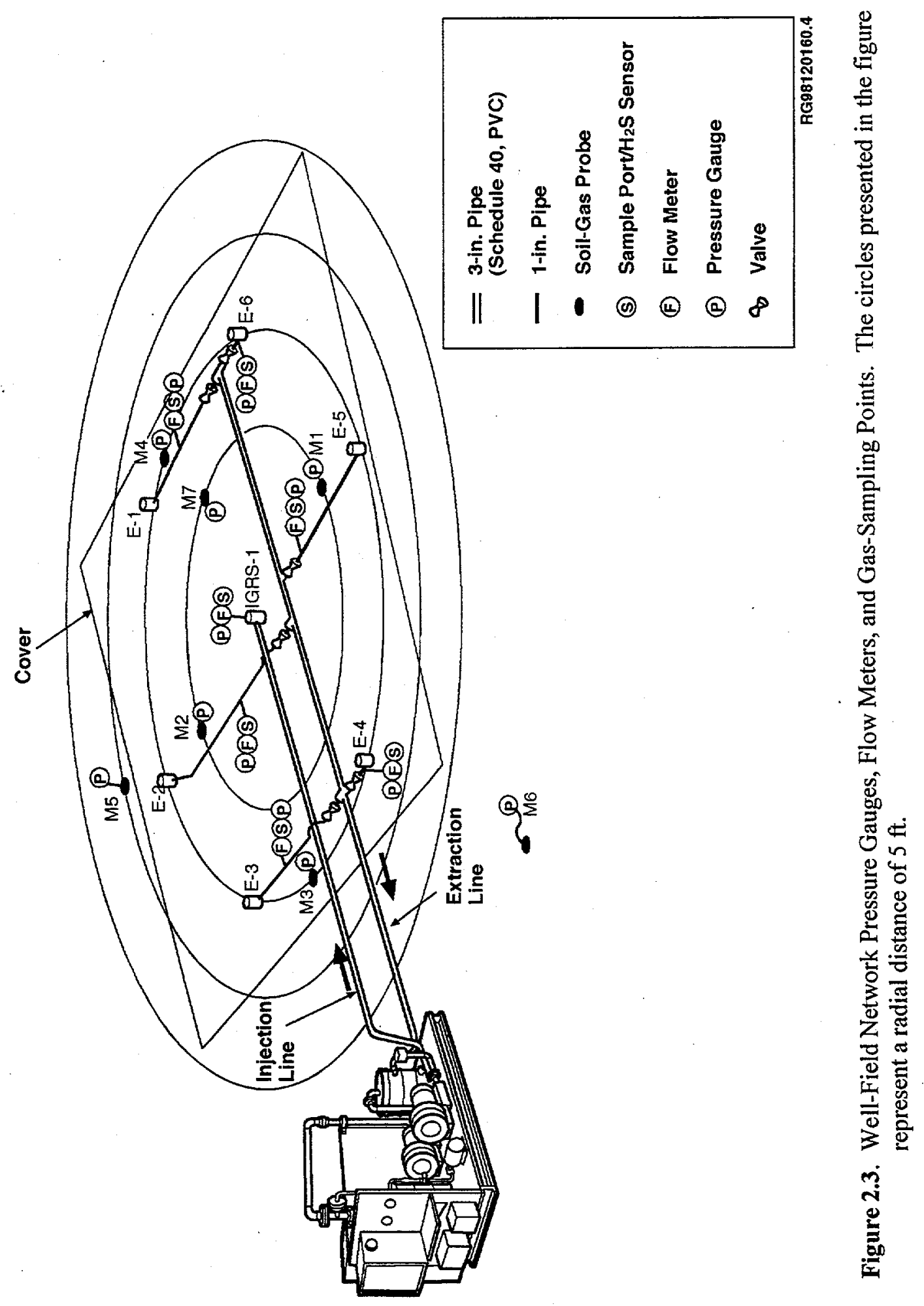




\subsection{Test Site Description and History}

The waste site used for this demonstration is known as Solid Waste Management Unit (SWMU) 143 (i.e., Chromate Spill Waste Site) and is situated in the corner of an equipment storage yard at the HighEnergy Laser System Test Facility (HELSTF) on the White Sands Missile Range (Figure 3.1).

\subsection{Regional Geology}

The White Sands Missile Range lies within the Mexican Highland Section of the Basin and Range Province and is characterized by a series of tilted fault blocks that form longitudinal, asymmetric ridges or mountains and broad intervening basins. The major portion of the White Sands Missile Range lies within the Tularosa Basin, which is bounded on the west by the Organ, San Agustin, and San Andres Mountains (see Figure 1.2). The eastern limit of the Tularosa Basin lies outside the White Sands Missile Range and is formed from north to south by the Jicarilla, Sierra Blanca, and Sacramento Mountains. The average elevation of the basin floor is $1,219 \mathrm{~m}$ above mean sea level, and surface features consist of flat sandy areas, sand dunes, basalt flows, and playas (dry lake beds).

The Tularosa Basin contains thick sequences of Tertiary and Quaternary alluvial and bolson-fill deposits. These sediments, $1,524 \mathrm{~m}$ thick in some areas, consist mainly of silt, sand, gypsum, and clay weathered from the surrounding mountain ranges. The nature of the bolson-fill deposits varies both laterally and vertically throughout basin. Coarse-grained, poorly sorted sediments deposited near mountain fronts grade into fine-grained, well-sorted sediments toward the center of the basin (Kelly and Hearne 1976). Sediments farther from the mountain fronts also contain a greater percentage of clay and gypsum. Vertically, the sediments are reported to become finer grained and more consolidated until reaching a laterally continuous clay unit at $\sim 300 \mathrm{~m}$ below ground surface (Kelly and Hearne 1976).

\subsection{History of Contamination}

The waste management unit (see Figure 3.1) was created in the early 1980 s when Entec 300, a $\mathrm{Cr}$ (VI)-based corrosion inhibitor, was released into the soil as a result of drum-mishandling operations. Deionized water containing $\mathrm{Cr}$ (VI) was in use at the time as a corrosion inhibitor and was circulated through a closed-loop coolant system of high-energy laser-testing units located at the HELSTF.

This waste management unit was first regulated under the State of New Mexico's Hazardous Waste Bureau regulations, which mandated the investigation of spills occurring before 1986 as part of the Resource Conservation and Recovery Act of 1976 (RCRA) Part B permit process. The New Mexico Ground Water Bureau protects groundwater with total dissolved solids concentrations below $10,000 \mathrm{mg} / \mathrm{L}$. Even though total dissolved solids in the shallow, "perched," and deeper, "regional," aquifers under the HELSTF average above $10,000 \mathrm{mg} / \mathrm{L}$, the New Mexico standards are still relevant for protecting potential future uses of the groundwater. It is believed the $\mathrm{Cr}(\mathrm{VI})$ contamination in the upper soils of SWMU 143 is the source of contamination locally observed in HELSTF groundwater. 


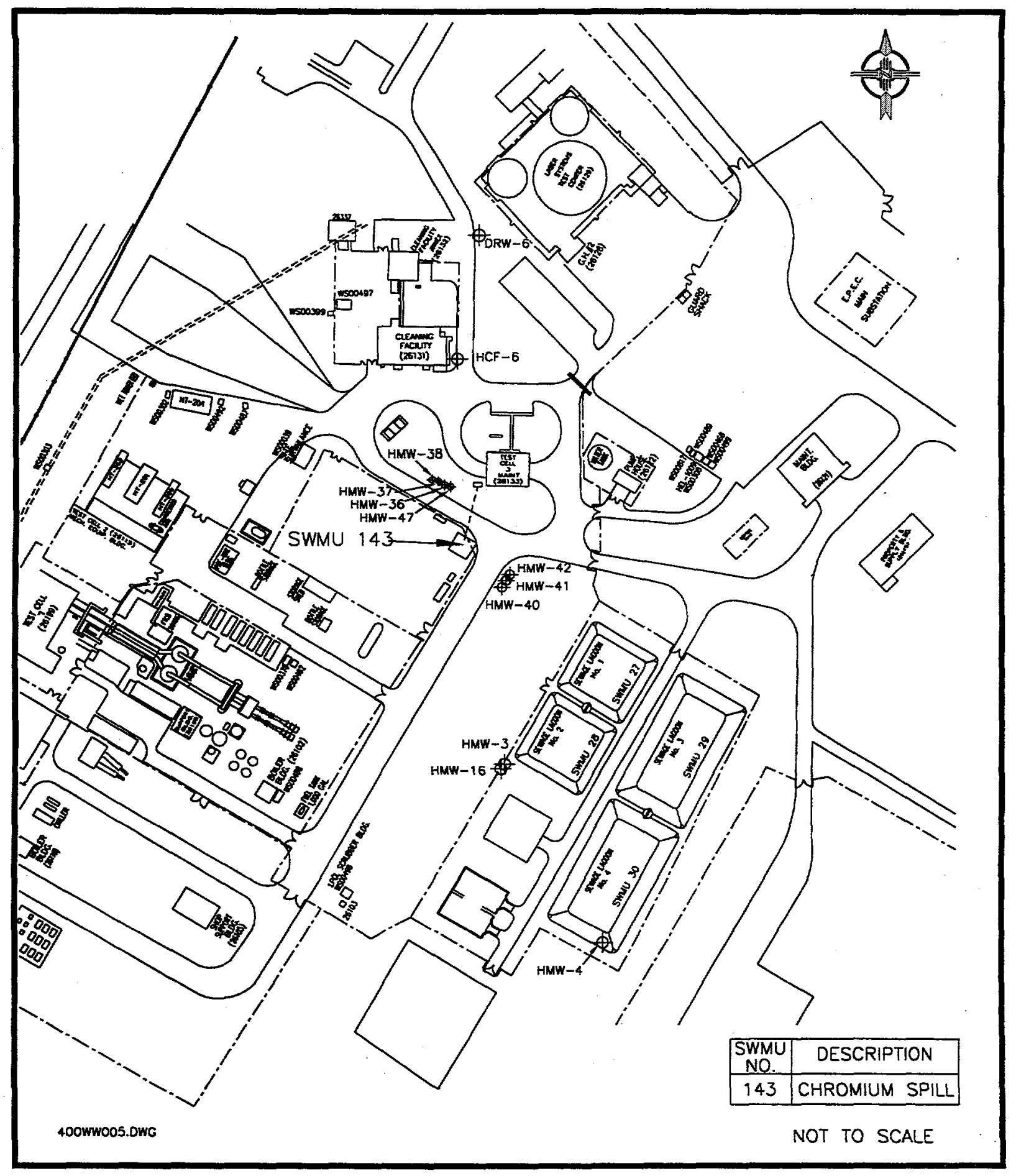

Figure 3.1. Location of Chromate Spill Waste Site 
A RCRA facility assessment was conducted at the HELSTF in 1988 to evaluate site conditions, former hazardous materials-disposal practices, potential sources of hazardous waste, hydrogeologic conditions, and potential for contamination of soil, surface water, and groundwater. The assessment identified a number of SWMUs at the HELSTF, including SWMU 143. As additional contaminants were found at the site, additional laws became applicable. Eventually, the site was added to the Hazardous and Solid Waste Amendments of 1984 outlined in the White Sands RCRA Part B permit.

Contamination was discovered at SWMU 143 in January 1990 when preparations were under way to pave the area. Greenish-yellow soil was found in the corner of the equipment yard; soil analysis was conducted and confirmed the presence of $\mathrm{Cr}$ (VI). A review of facility records in 1990 indicated that several 55-gal drums of the agent had spilled directly onto the ground in 1982 or 1983.

On initial discovery of the spill, efforts to remove the contaminated soil were undertaken by the HELSTF Support Services Contractor. Approximately 1755 -gal drums of $\mathrm{CrO}_{4}{ }^{2-}$-contaminated soil were excavated from the site in 1990. Clean closure could not be obtained, however, and the expensive excavation effort was stopped until a better cleanup method could be implemented. The site was overlain with several meters (feet) of clean fill and covered with a shingled wooden roof structure to inhibit leaching and run on.

\subsection{Previous Site Investigations}

To comply with the RCRA Part B permit process, SWMU 143 was investigated by several companies contracted by the U.S. Department of the Army. The goal of these investigations was the identification of an approach to clean up or immobilize the Cr(VI) from further contaminating the groundwater beneath the HELSTF.

In 1992, three shallow borings were drilled at SWMU 143 during a Phase I RCRA facility investigation. Results of analyses for 8 soil samples collected from 10 to $30 \mathrm{ft}$ deep indicated slightly elevated total $\mathrm{Cr}$. A maximum total $\mathrm{Cr}$ concentration of $14 \mathrm{mg} / \mathrm{kg}$ was reported for a sample collected at $10 \mathrm{ft}$ in Phase I soil borehole 03 . All other metal concentrations were near background levels. Green-tinted soil was also observed at the site, suggesting the presence of residual $\mathrm{Cr}(\mathrm{VI})$. A groundwater sample taken from HELSTF monitoring well 11 contained $\mathrm{Cr}(\mathrm{VI})$, total $\mathrm{Cr}$, and 1,1- dichloroethylene levels exceeding federal and state maximum contaminant levels and state groundwater-protection standards. The water had a strong greenish-yellow tint. It is believed that the chlorinated solvents did not originate in SWMU 143.

An additional six 10-ft soil borings were subsequently completed during a Phase II RCRA facility investigation performed in 1993, and soil samples collected from ground surface, 4 , and $9 \mathrm{ft}$ were analyzed for $\mathrm{Cr}$. Neither total $\mathrm{Cr}$ nor $\mathrm{Cr}(\mathrm{VI})$ were detected above their quantitation limits $(\sim 6 \mathrm{mg} / \mathrm{kg})$. Consideration of the location and depth of these boreholes, however, suggests that they were possibly situated outside the contamination zone. Analysis of groundwater samples indicated $\mathrm{Cr}$ contamination in nearby monitoring wells exceeded the federal and state maximum contaminant levels and the state groundwater-protection standards. In addition, six solvent compounds were also detected at the site. These compounds were attributed to a neighboring diesel spill. 


\subsection{Local Hydrogeologic Setting}

Very little surface water exists at the White Sands Missile Range because of the low annual precipitation and high evaporation rate. Playas within the basin may contain standing water during the summer season when thunderstorm activity is most prevalent. Streams that drain the surrounding mountains usually contain water only following a heavy precipitation event. The Tularosa Basin is a closed basin, with no surface-water drainage outside of the White Sands Missile Range. Much of White Sands surface water drains east-northeast toward Lake Lucero, a large playa in the center of the basin, where it evaporates (see Figure 1.2).

The bolson-fill aquifer consists of a wedge-shaped belt of potable water in the coarse, unconsolidated alluvial fan deposits along the eastern flanks of the Organ and San Andres Mountains. Farther to the east near the test site, this water becomes progressively more mineralized, primarily with sulfate and chloride. This is attributed to the slow migration rate of groundwater and the presence of readily soluble minerals in the bolson sediments.

Groundwater in the vicinity of the HELSTF is characterized by total dissolved solids content of generally more than $10,000 \mathrm{mg} / \mathrm{L}$, making it not potable. As such, the HELSTF obtains its water supply from three wells located $\sim 13 \mathrm{~km}$ northwest, at the base of the San Andres Mountains.

Groundwater below the HELSTF exists in the regional aquifer and also within several discontinuous, perched aquifers. The average depth to the top of the water in the regional groundwater aquifer is $\sim 21$ to $23 \mathrm{~m}$, with a southeast flow direction (MEVATEC 1997). The deep, regional aquifer has reported total dissolved solids concentrations ranging from 5,940 to $111,000 \mathrm{mg} / \mathrm{L}$ at 89 and $248 \mathrm{~m}$, respectively (Basabilvazo et al. 1994).

A series of hydraulically interconnected, discontinuous, perched water-bearing zones overlying the regional aquifer in the vicinity of the HELSTF have been identified by Tetra Tech (1997). Water-level information indicates that multiple, vertical, perched zones are encountered in the areas of wastewater discharge. Perched-water zones have been identified between $\sim 5$ to 6 and at $15 \mathrm{~m}$ below ground surface. These shallow, perched-water zones are believed to exist primarily from recharge of effluent discharge areas originating from the sewage lagoons and other facilities (see Figure 3.1).

The information available to date has been utilized to develop the conceptual hydrogeologic model presented in Figure 3.2. This cross section suggests that water infiltrating the vadose zone from HELSTF sewage lagoons may move laterally across a shallow, perched zone toward SWMU 143. This zone corresponds to a clay layer present at $\sim 5 \mathrm{~m}$ below SWMU 143. Cr(VI) reaching the shallow, perched zone beneath the site may thus be transported laterally. As Figure 3.2 suggests, this layer may pinch out, allowing the contaminated water to cascade downward to a deeper, perched zone and from there down to the regional aquifer. This model illustrates the importance of immobilizing $\mathrm{Cr}(\mathrm{VI})$ in the soils at SWMU 143 because this site appears to be an important source of contamination to the regional aquifer. 


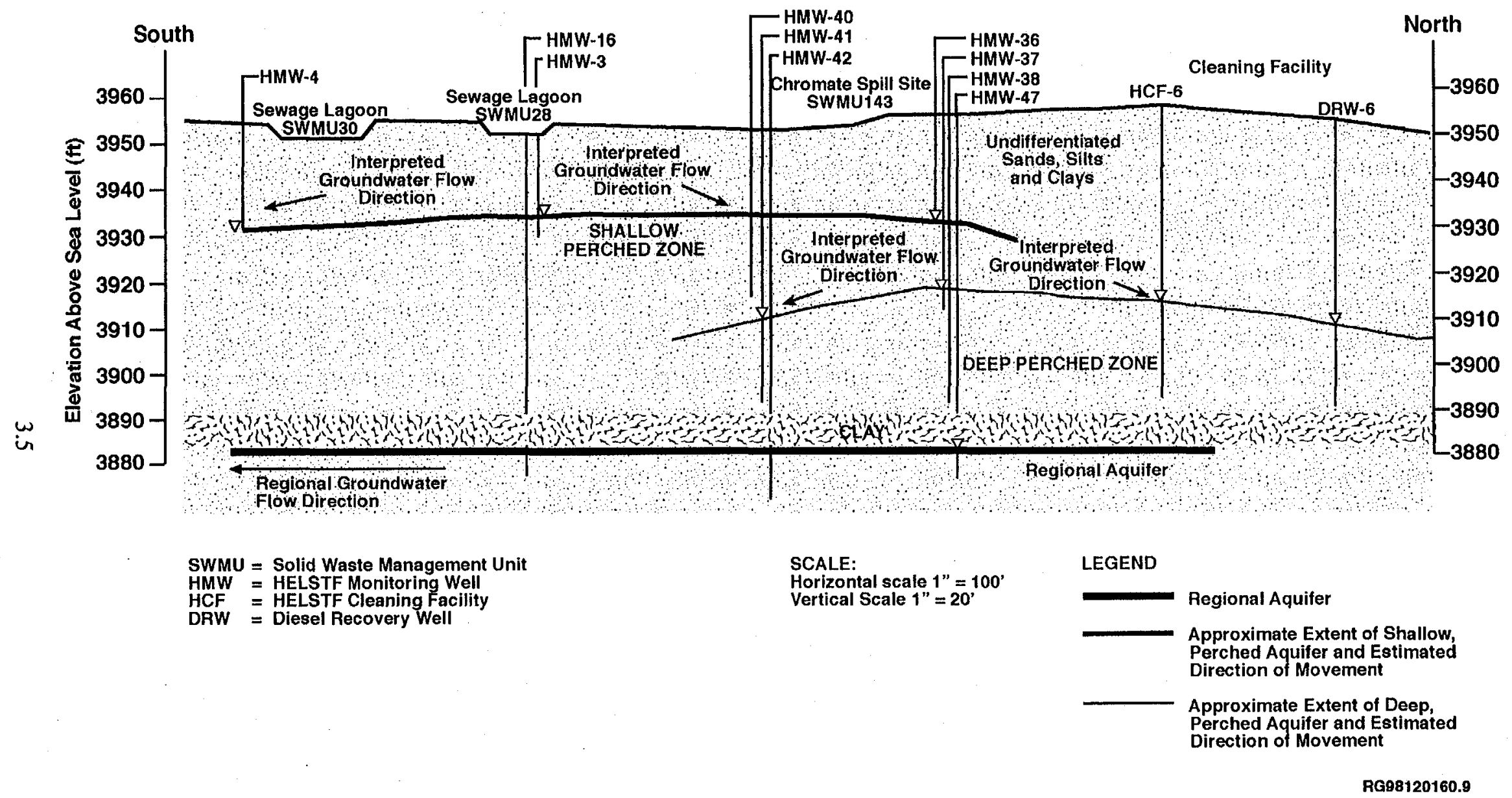

Figure 3.2. North to South Regional Cross Section of Study Area (source: MEVATEC Corporation) 


\subsection{Pretreatment Site Characterization and Well-FieId Installation}

In 1996, the U.S. Department of Energy proposed injecting diluted $\mathrm{H}_{2} \mathrm{~S}$ into soil to chemically reduce $\mathrm{Cr}$ (VI) to $\mathrm{Cr}$ (III), thus immobilizing and detoxifying it as a remediation approach. SWMU 143 was made available to demonstrate the IGRS approach, and a test plan was prepared (Thornton and Miller 1996 and updated in $1998^{1}$ ).

Detailed information regarding data-collection activities was provided in sampling and analysis plans. ${ }^{2,3}$ The demonstration involved drilling pre- and posttest characterization boreholes, installing gassampling points, and installing the extraction wells, as illustrated in Figure 4.1.

Pretest characterization was conducted in April and August 1996. ${ }^{2}$ The objectives of the pretest characterization effort were to determine the distribution and magnitude of $\mathrm{Cr}$ (VI) contamination at SWMU 143 and to provide sufficient samples for treatability testing. The geology and, particularly, the gas permeability of the sediments in the area of SWMU 143 were important components in the design and operation of the gaseous injection system. Also undertaken was the performance of a vacuum pump test to assess air permeability at the site. Final well-field installation was accomplished in September 1996 with completion of the extraction wells.

\subsection{Site Geologic Investigation}

Characterization boreholes were drilled with a GeoProbe, a hydraulically powered percussion/probing machine that uses a "direct push" technique (i.e., tool or sensor inserted into the ground with the use of drilling to remove soil and make a path for the tool). Soil sampling was performed with a Macro-Core ${ }^{(B)}$ GeoProbe Soil Sampler. Sampling was conducted with a 45 - by 1.5 -in.-dia. open-tube sampler. Polyethyleneterephthlate liners, which are resistant to a variety of chemicals including dilute acids and salts, were used to encase the collected soil cores.

Soil sampling began at the approximate center of SWMU 143 with borehole GP1 (see Figure 4.1) in April 1996. ${ }^{4}$ Three additional boreholes were drilled around GP1 (GP2, GP3, and GP4) and sampling was undertaken. Samples were collected in a series of cores from the ground surface until a lower clay

\footnotetext{
${ }^{1}$ Thornton, EC, TJ Gilmore, and $\mathrm{KB}$ Olsen. 1998. Treatability test plan for the in situ gas treatment demonstration. Pacific Northwest National Laboratory, Richland, Washington.

${ }^{2}$ Marozas, DC. 1996. Chromium verification drilling project, SWMU 143, project operation plansampling and analysis.' Sandia National Laboratories, Los Alamos, New Mexico.

${ }^{3}$ Thornton, EC, GV Last, TJ Gilmore, and KB Olsen. 1998. Sampling and analysis plan for the in situ gas treatment demonstration. Pacific Northwest National Laboratory, Richland, Washington.

${ }^{4}$ Miller, RD. 1996. HELSTF SWMU-143 geology. Westinghouse Hanford Company, Richland, Washington.
} 


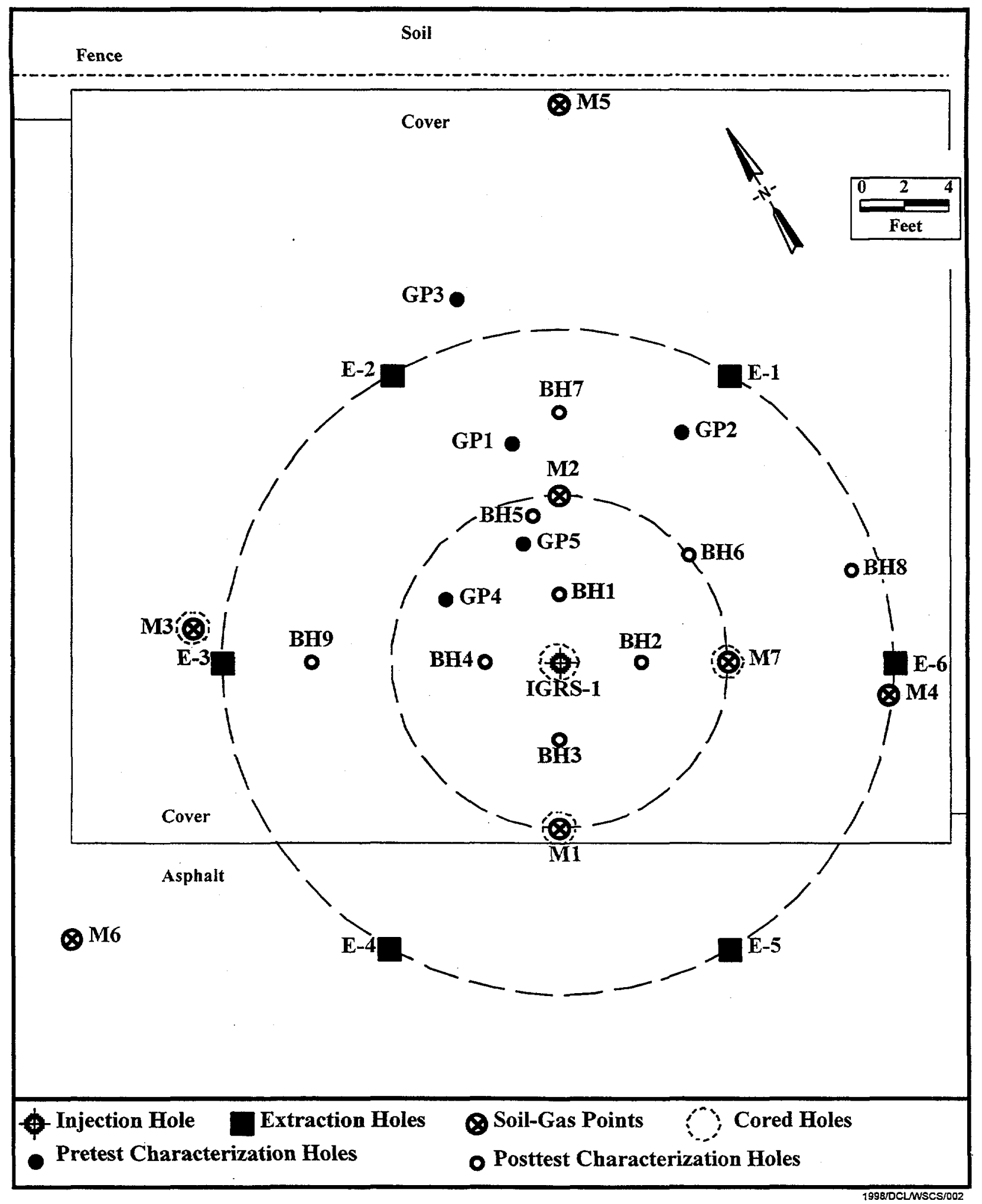

Figure 4.1. Configuration of Well-Field Network, Soil-Gas Points, and Soil-Sampling Locations 
was encountered ( $\sim 20 \mathrm{ft}$ below ground surface). Based on soil recovery achieved in the first four holes and on preliminary onsite $\mathrm{Cr}(\mathrm{VI})$ analyses, ${ }^{1}$ a decision was made to collect samples from an additional borehole (GP5).

The central injection hole (IGRS-1) was drilled, and additional soil samples were collected in August 1996 based on the results of the first characterization effort. Additional soil samples were collected in August 1996 during installation of the soil-gas-monitoring points (M1, M3, and M7).

Geologic logging was conducted by an onsite geologist during the drilling and coring operations and included mineralogical and stratigraphic descriptions and visual observations of soil characteristics. The near-surface geology of SWMU 143 is illustrated in the generalized stratigraphic section presented in Figure 4.2.

The site is a layered sedimentary system deposited in a fluvial/aeolian/lacustrine environment. The sediments are clastic and predominantly fine grained, with $>50 \%$ of the grains smaller than $1 \mathrm{~mm}$ in diameter. Unlike more typical clastic systems that are primarily silica based, the upper $18 \mathrm{ft}$ at the site are composed primarily of gypsum. Gypsum tends to retain higher moisture content because of its hygroscopic nature and is more susceptible to secondary cementation and alteration following deposition than are silica-based clastic systems. The porosity and permeability in the gypsum appear to be controlled more by the degree of cementation than by the grain-size distribution. A clay layer at $18 \mathrm{ft}$ below the surface thus represents the base of the zone selected for gas-injection testing.

Within the upper $18 \mathrm{ft}$, at least 3 distinct layers were identified by visual inspection and were further defined by soil-moisture, calcium $(\mathrm{Ca})$, iron $(\mathrm{Fe})$, and $\mathrm{Cr}$ distributions. From the surface to a depth of $\sim 3.7 \mathrm{ft}$, the sediments were surficial material or fill material added following the initial excavation of contaminated sediments. Between 3.7 and $\sim 10 \mathrm{ft}$, the sediments were a white, clean, well-sorted sand. This was also the layer that contained the majority of the contamination. Between $\sim 10$ and $18 \mathrm{ft}$, the sediments were composed of a pale brown, silty, gypsum sand. The cementation and silt content of this unit appeared to vary laterally across the site. Below the pale brown layer was a silty clay. This silty clay formed a matrix that contained gypsum crystals to 0.5 -in. dia. Perched water was observed to collect seasonally above this layer.

The deepest soil boring (GP1) at the site reached $36 \mathrm{ft}$ below ground surface. In this borehole and in GP2 and GP3, the silty clay layer, which formed the lower boundary of the site during the injection test, continued down to $\sim 23.5 \mathrm{ft}$, where it graded to a silty sand between 23.5 and $28.9 \mathrm{ft}$ and then to a sand at 28.9 to $33.7 \mathrm{ft}$. Another clayey silt was encountered at $33.7 \mathrm{ft}$ and continued at least to the bottom of the borehole at $36 \mathrm{ft}$.

\footnotetext{
${ }^{1}$ Thornton, EC, GV Last, TJ Gilmore, and KB Olsen. 1998. Sampling and analysis plan for the in situ gas treatment demonstration. Pacific Northwest National Laboratory, Richland, Washington.
} 


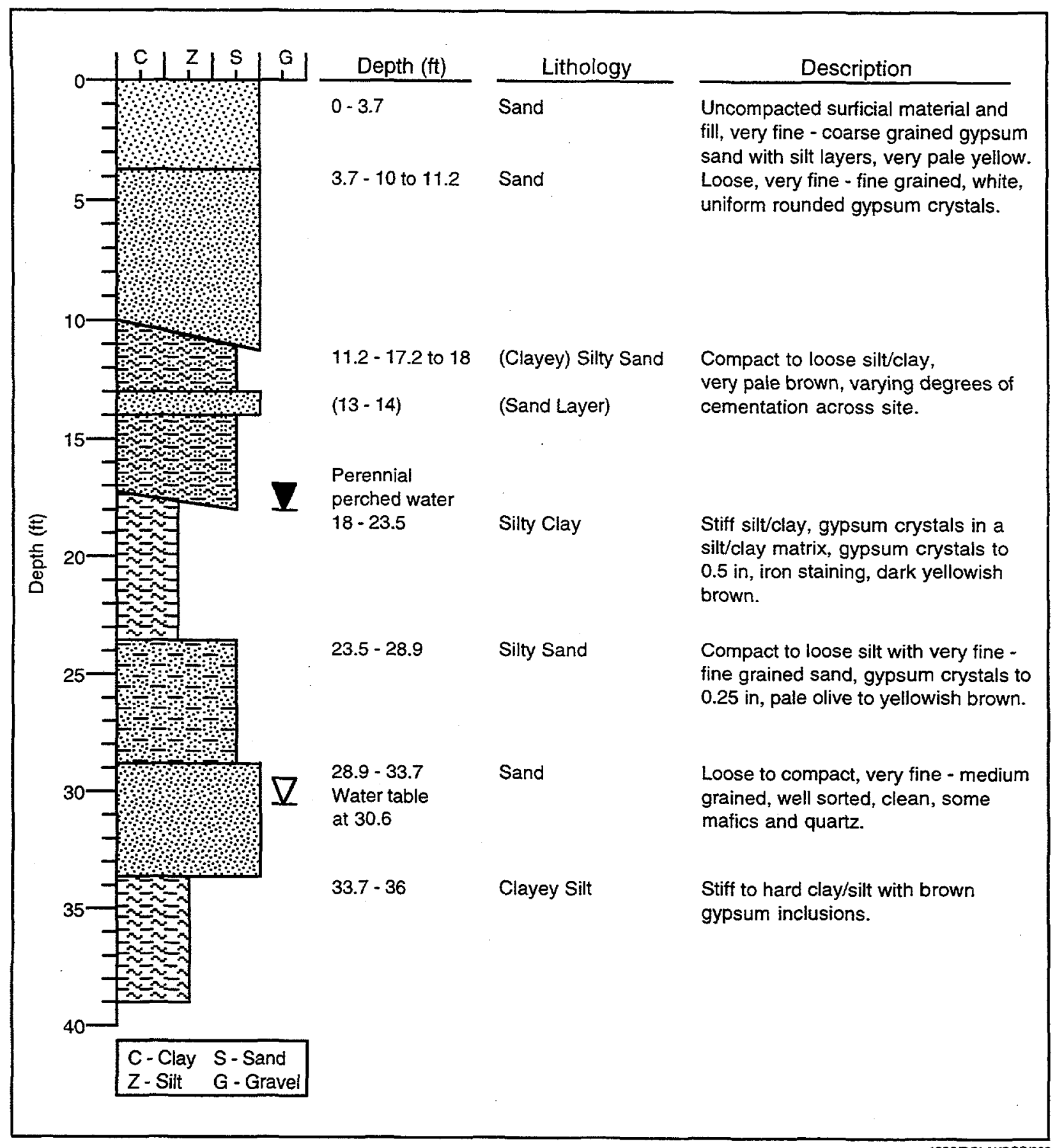

1998DCLWSCS1003

Figure 4.2. Generalized Stratigraphic Section for Chromate Spill Waste Site 


\subsection{Site Chemical and Geotechnical Characteristics}

Soil samples collected during the first stage of characterization (boreholes GP1 through GP5; April 1996) were sent to an offsite commercial laboratory for analysis using standard contract laboratory protocols approved for implementation of RCRA-permitted hazardous waste-treatment projects (EPA 1992). Analytes included metals, total $\mathrm{Cr}, \mathrm{Cr}(\mathrm{VI})$, total $\mathrm{Fe}$, ferrous (Fe[II]) and ferric (Fe[III]) $\mathrm{Fe}$, total organic carbon, and mercury $(\mathrm{Hg})^{1,2}$ Metals and total $\mathrm{Cr}$ were analyzed using Method 6010; $\mathrm{Cr}$ (VI) was determined by Method 7196. Selected analytes are presented in Table 4.1 and are discussed below. The only significant contaminant identified in site soils was $\mathrm{Cr}(\mathrm{VI}){ }^{2}$. Soil samples were also collected during the second stage of characterization (boreholes IGRS-1, M1, M3, M7) and analyzed by a laboratory at White Sands Missile Range for Cr(VI) by Method 7196 (Table 4.2).

Geotechnical tests were also conducted on selected soil samples, including determination of moisture content, bulk density, grain-size distribution, and permeability (WHC 1990, PNL 1993). Moisturecontent data (obtained using American Society for Testing and Materials protocols described in WHC 1990) are presented in Table 4.2 and discussed below. Bulk density (measured on three repacked soil columns) was determined to be $86.2 \mathrm{lb} / \mathrm{ft}^{3}$. Grain-size distributions were also performed on several site soil samples and indicated a silty sand to sandy silt, with an average grain size of $\sim 0.1 \mathrm{~mm}$. An intrinsic permeability value of 3.61 darcies was obtained on a site soil sample based on laboratory air permeability measurements.

On December 17, 1997, soil-gas samples were collected from 3 extraction wells (E-1, E-3, E-4; see Figure 4.1) and 1 ambient air blank sample was collected. Samples were collected in SUMMA ${ }^{\mathrm{TM}}$ canisters and sent to Pacific Northwest National Laboratory for analysis. ${ }^{1}$ Trace-level concentrations of several volatile and semivolatile compounds were identified, ${ }^{2}$ but were below levels that could impact airquality standards in the HELSTF area during the demonstration.

Presented below is a discussion of selected geochemical and geotechnical parameters of special importance to the demonstration and their relationship to the site geology.

\subsubsection{Soil-Moisture Content}

The moisture content in the gypsum sand soil samples collected while drilling IGRS-1 ranged from $17.6 \%$ to $35.9 \%$ moisture by weight (see Table 4.2 and Figure 4.3 ). The stratigraphic changes in the sediments of the upper $18 \mathrm{ft}$ of the site generally match the variations in moisture content. Sediments in the upper 4 to $6 \mathrm{ft}$ contained moisture contents of $\sim 20 \%$. From 7 to $13 \mathrm{ft}$, soil-moisture content ranged from $30 \%$ to $35 \%$, reflecting the change to a gypsum-rich sand.

\footnotetext{
${ }^{1}$ Thornton, EC, GV Last, TJ Gilmore, and KB Olsen. 1998. Sampling and analysis plan for the in situ gas treatment demonstration. Pacific Northwest National Laboratory, Richland, Washington. ${ }^{2}$ Thornton, EC, GV Last, TJ Gilmore, and KB Olsen. 1998. Pre-test analytical results for soil, groundwater and soil gas at the demonstration site. Pacific Northwest National Laboratory, Richland, Washington.
} 
Table 4.1. Pretest Geochemical Data from GP-Series Core Samples from Chromate Spill Waste Site

\begin{tabular}{|c|c|c|c|c|c|c|c|c|}
\hline $\begin{array}{l}\text { Sampling } \\
\text { Location }\end{array}$ & $\begin{array}{c}\text { Depth } \\
\text { (ft) }\end{array}$ & $\begin{array}{c}\mathrm{Cr}(\mathrm{VI}) \\
(\mathrm{mg} / \mathrm{kg})\end{array}$ & $\begin{array}{l}\text { Total Cr } \\
(\mathrm{mg} / \mathrm{kg})\end{array}$ & $\begin{array}{c}\mathrm{Fe}(\mathrm{II}) \\
(\mathrm{mg} / \mathrm{kg})\end{array}$ & $\begin{array}{c}\mathrm{Fe}(\mathrm{III}) \\
(\mathrm{mg} / \mathrm{kg})\end{array}$ & $\begin{array}{l}\text { Total Fe } \\
(\mathrm{mg} / \mathrm{kg})\end{array}$ & $\begin{array}{c}\mathrm{TOC}^{(\mathrm{a})} \\
(\mathrm{mg} / \mathrm{kg})\end{array}$ & $\begin{array}{c}\mathrm{Ca} \\
(\mathrm{mg} / \mathrm{kg})\end{array}$ \\
\hline \multirow[t]{8}{*}{ GP1 } & 9 & 0.47 & 15 & 100 & 420 & 5,200 & 1,600 & 200,000 \\
\hline & 16 & 1.3 & 7.9 & 97 & 1,300 & 4,100 & 3 & 190,000 \\
\hline & 22 & 0.26 & 23 & 27 & 27 & 24,000 & 3 & 45,000 \\
\hline & 26 & 0.035 & 8.4 & 23 & 180 & 7,600 & 1,700 & 65,000 \\
\hline & 30 & 0.077 & 5.3 & 21 & 470 & 8,000 & 3 & 1,200 \\
\hline & 32 & 0.036 & 6.7 & 24 & 560 & 9,100 & 3 & 7,700 \\
\hline & 34 & 0.036 & 5.8 & 24 & 610 & 8,400 & 230 & 4,600 \\
\hline & 36 & 0.044 & 17 & 59 & 420 & 16,000 & 1,900 & 94,000 \\
\hline \multirow[t]{7}{*}{ GP2 } & 4 & 0.16 & 4.8 & 71 & 740 & 1,800 & 1,300 & 200,000 \\
\hline & 8 & 10 & 13 & 180 & 1,200 & 1,800 & 3 & 180,000 \\
\hline & 10 & 0.53 & 4.1 & 180 & 970 & 2,700 & 200 & 220,000 \\
\hline & 11 & 0.12 & 3.7 & 120 & 840 & 2,100 & 460 & 210,000 \\
\hline & 18 & 0.13 & 9.2 & 100 & 2,400 & 9,700 & 480 & 130,000 \\
\hline & $18 \mathrm{D}$ & 0.25 & 13 & 130 & 2,100 & 13,000 & 600 & 110,000 \\
\hline & 30 & 0.069 & 13 & 74 & 1,200 & 13,000 & 3 & 1,300 \\
\hline \multirow[t]{6}{*}{ GP3 } & 8 & 0.041 & 3.3 & 190 & 820 & 2,700 & 3,400 & 200,000 \\
\hline & 11 & 0.16 & 3.5 & 150 & 980 & 2,700 & 3 & 220,000 \\
\hline & 14 & 0.082 & 6.8 & 130 & 690 & 3,400 & 81 & 210,000 \\
\hline & 18 & 0.065 & 15 & 140 & 3,900 & 16,000 & 520 & 130,000 \\
\hline & $18 \mathrm{D}$ & 0.1 & 19 & 91 & 3,600 & 17,000 & 3 & 100,000 \\
\hline & 26 & 0.037 & 22 & 68 & 1,800 & 23,000 & 3 & 15,000 \\
\hline \multirow[t]{5}{*}{ GP4 } & 8 & 1.2 & 5.4 & 180 & 990 & 2,200 & 3 & 210,000 \\
\hline & 11 & 7.6 & 12 & 160 & 790 & 1,400 & 370 & 250,000 \\
\hline & 11 & 7 & 12 & 150 & 700 & 1,900 & 130 & 260,000 \\
\hline & 14 & 1.1 & 11 & 200 & 490 & 4,800 & 3 & 190,000 \\
\hline & 18 & 2.4 & 14 & 130 & 3,800 & 14,000 & 3 & 110,000 \\
\hline \multirow[t]{5}{*}{ GP5 } & 4 & 0.37 & 19 & 110 & 1,100 & 5,800 & 1,700 & 170,000 \\
\hline & 8 & 21 & 46 & 100 & 27 & 4,200 & 14,000 & 190,000 \\
\hline & 10 & 22 & 32 & 130 & 1,700 & 4,400 & 300 & 250,000 \\
\hline & 14 & 7.7 & 20 & 190 & 680 & 4,300 & 3 & 200,000 \\
\hline & 18 & 1.9 & 27 & 140 & 5,100 & 27,000 & 2,200 & 63,000 \\
\hline $\begin{array}{l}\text { (a) Total o } \\
\mathrm{D}=\text { Duplica }\end{array}$ & \multicolumn{8}{|c|}{ (a) Total organic carbon. } \\
\hline
\end{tabular}


Table 4.2. Pretest Geochemical Data from IGRS-1 and M-Series Core Samples from Chromate Spill Waste Site

\begin{tabular}{|c|c|c|c|}
\hline Sampling Location & Depth $(\mathrm{ft})$ & $\mathrm{Cr}(\mathrm{VI})(\mathrm{mg} / \mathrm{kg})$ & Moisture (\%) \\
\hline \multirow{16}{*}{ IGRS-1 } & 1 & -- & 19.4 \\
\hline & 2 & 0.76 & -- \\
\hline & 3 & - & 17.6 \\
\hline & 4 & 1.5 & $\cdots$ \\
\hline & 5 & - & 22.8 \\
\hline & 6 & 2.9 & -- \\
\hline & 7 & - & 31.6 \\
\hline & 8 & 85 & -- \\
\hline & 9 & -- & 28.1 \\
\hline & 10 & 45 & -- \\
\hline & 11 & -- & 32.7 \\
\hline & 12 & 0.15 & $-\cdots$ \\
\hline & 13 & -- & 35.9 \\
\hline & 14 & $<0.04$ & -- \\
\hline & 15 & 8 & 34.1 \\
\hline & 18 & $<0.04$ & - \\
\hline \multirow[t]{10}{*}{$\mathrm{Ml}$} & 2 & 0.06 & - \\
\hline & 4 & $<0.04$ & -- \\
\hline & 6 & $<0.04$ & -- \\
\hline & 8 & $<0.04$ & -- \\
\hline & 10 & $<0.04$ & -- \\
\hline & 12 & $<0.04$ & -- \\
\hline & 14 & $<0.04$ & -- \\
\hline & $14 \mathrm{D}$ & $<0.04$ & $\overline{--}$ \\
\hline & 16 & $<0.04$ & -- \\
\hline & 18 & $<0.04$ & -- \\
\hline \multirow[t]{10}{*}{ M3 } & 2 & $<0.04$ & -- \\
\hline & 4 & $<0.04$ & - \\
\hline & 6 & $<0.04$ & - \\
\hline & 8 & $<0.04$ & - \\
\hline & 10 & 0.46 & - \\
\hline & 12 & $<0.04$ & $\ldots$ \\
\hline & 14 & $<0.04$ & -- \\
\hline & $14 \mathrm{D}$ & $<0.04$ & -- \\
\hline & 16 & $<0.04$ & - \\
\hline & 18 & $<0.04$ & -- \\
\hline \multirow[t]{9}{*}{ M7 } & 2 & $<0.04$ & -- \\
\hline & 4 & $<0.04$ & - \\
\hline & 6 & 15 & - \\
\hline & 8 & 13 & - \\
\hline & 10 & 0.21 & - \\
\hline & 12 & 0.04 & -- \\
\hline & 14 & $<0.04$ & - \\
\hline & 16 & $<0.04$ & - \\
\hline & 18 & $<0.04$ & -- \\
\hline
\end{tabular}




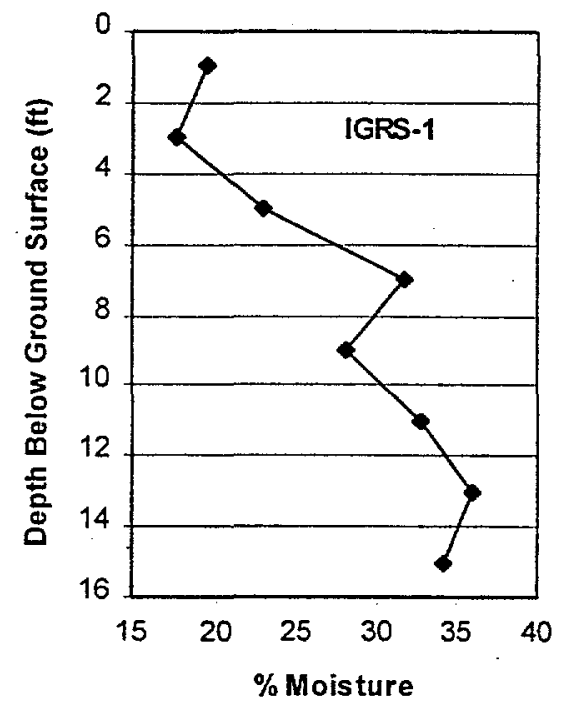

Figure 4.3. Depth Profile for Pretest Soil-Moisture Content

\subsubsection{Calcium}

$\mathrm{Ca}$ was the major elemental constituent observed in the analysis of the core sediment samples. $\mathrm{Ca}$ is associated primarily with the gypsum $\left(\mathrm{CaSO}_{4} \cdot 2 \mathrm{H}_{2} \mathrm{O}\right)$ component of the sand and also with minor amounts of calcium carbonate $\left(\mathrm{CaCO}_{3}\right)$. Figure 4.4 presents the profile of the average percent $\mathrm{Ca}$ versus depth, where average $\mathrm{Ca}$ was obtained by averaging $\mathrm{Ca}$ values of core samples obtained from the same depth at the site. Percent $\mathrm{Ca}$ ranged from the upper teens to lower $20 \%$ level in the interval from 4 to $16 \mathrm{ft}$. By $18 \mathrm{ft}$, however, the Ca concentration decreased to $10.3 \%$ and to levels below $10 \%$ at greater depths. This behavior reflects a significant change in the stratigraphy of the site between 16 and $20 \mathrm{ft}$, where the sediment mineralogical composition transitions from dominantly gypsum to aluminosilicate clays, and coincides with the brown sand interval.

\subsubsection{Chromium, Iron, and Organic Carbon}

The chemical constituent of concern is $\mathrm{Cr}(\mathrm{VI})$, which should be reduced to $\mathrm{Cr}$ (III) after reaction with injected $\mathrm{H}_{2} \mathrm{~S}$. However, the consumption of $\mathrm{H}_{2} \mathrm{~S}$ by soil is also related to other oxidized constituents, particularly Fe(III). Also, an understanding of the overall oxidation capacity of the soil is useful in predicting treatment progress, results, and potential long-term effectiveness. Thus, a review of the analytical data for redox constituents is undertaken in this section, consisting of the data available for $\mathrm{Cr}(\mathrm{VI})$, total $\mathrm{Cr}, \mathrm{Fe}(\mathrm{II}), \mathrm{Fe}(\mathrm{III})$, total $\mathrm{Fe}$, and total organic carbon.

Figure 4.5 compares the average concentration of $\mathrm{Cr}(\mathrm{VI})$ and total $\mathrm{Cr}$ as a function of depth. The average $\mathrm{Cr}$ concentrations were determined by averaging the value from each core sample from a similar depth segment across the test site (e.g., all values from $8 \mathrm{ft}$ below ground surface). Concentrations of 


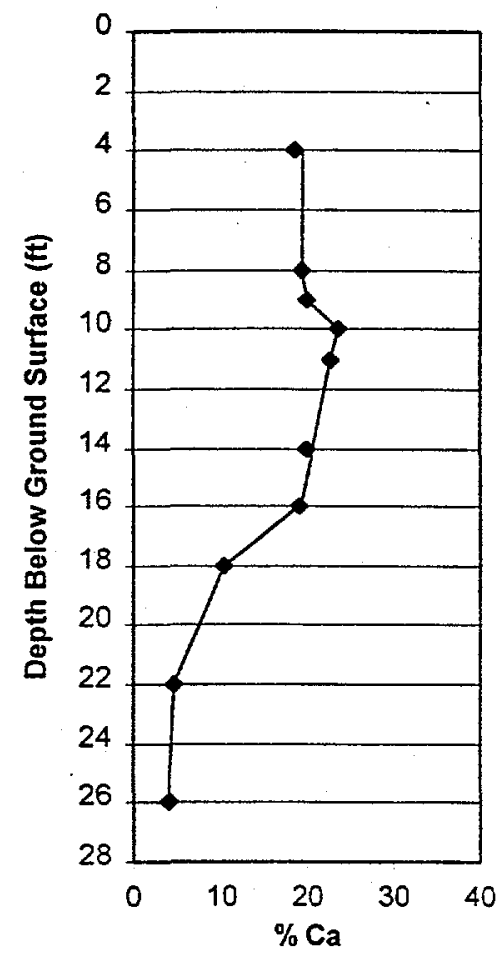

Figure 4.4. Depth Profile for Average Calcium Concentration

both constituents are found to be highly variable with depth, but in all situations, the total $\mathrm{Cr}$ concentrations exceed the $\mathrm{Cr}(\mathrm{VI})$ concentration. Based on these results, the average background concentration of total $\mathrm{Cr}$ is $\sim 10 \mathrm{mg} / \mathrm{kg}$. Background concentrations of $\mathrm{Cr}(\mathrm{VI})$ are expected to be zero. The region of highest $\mathrm{Cr}(\mathrm{VI})$ concentration was found between 8 and $10 \mathrm{ft}$, with a maximum observed concentration of $85 \mathrm{mg} / \mathrm{kg}$ at a depth of $8 \mathrm{ft}$ in IGRS-1. In this depth range, a major percentage of the total $\mathrm{Cr}$ was found to be $\mathrm{Cr}(\mathrm{VI})$ (see Tables 4.1 and 4.2).

In natural soils and sediments, $\mathrm{Fe}$ exists as either Fe(II) or Fe(III). The oxidation state of Fe in the environment is dependent on whether it is present in an aerobic or anaerobic environment. The $\mathrm{Fe}$ at the test site is expected to be predominately Fe(III) because the sediments exist under aerobic/oxidized conditions. Fe(III) is expected to be the major reactant with $\mathrm{H}_{2} \mathrm{~S}$ in the sediment matrix because there is considerably more $\mathrm{Fe}(\mathrm{III})$ present than $\mathrm{Cr}(\mathrm{VI})$.

Figure 4.6 presents the average $\mathrm{Fe}(\mathrm{II}), \mathrm{Fe}(\mathrm{III})$, and total Fe concentrations for all pretest core samples as a function of depth. Concentrations of $\mathrm{Fe}$ (II) or $\mathrm{Fe}$ (III) were highly variable with depth, but $\mathrm{Fe}$ is shown to be primarily in the oxidized Fe(III) state. Average concentrations of Fe(II) ranged from 91 to $173 \mathrm{mg} / \mathrm{kg}$, whereas average concentrations of Fe(III) ranged from 420 to $3,725 \mathrm{mg} / \mathrm{kg}$. There was a noticeable increase of Fe(III) concentration between 16 and $18 \mathrm{ft}$, where concentrations increased from 1,300 to $3,725 \mathrm{mg} / \mathrm{kg}$. This interval corresponds to the zone where a change from gypsum sand to predominantly clay was observed during the geologic evaluation. 


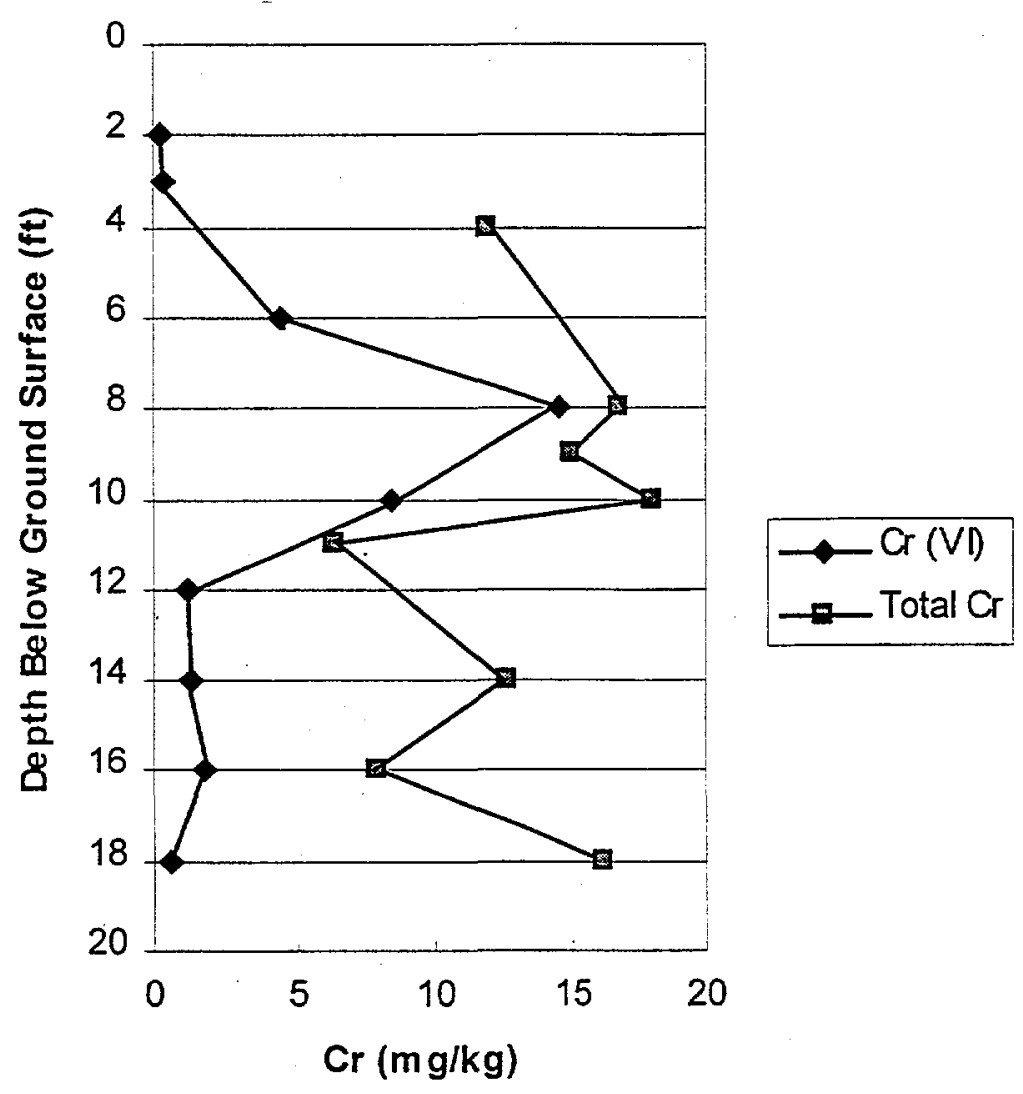

Figure 4.5. Depth Profiles for Average Pretest Soil Hexavalent Chromium and Total Chromium Concentrations

Total Fe in the core sediment samples can be considered a minor element. Average concentrations ranged from 2,067 to $16,675 \mathrm{mg} / \mathrm{kg}$. See Figure 4.6 for a profile of total Fe concentration versus depth. The depth profile shows that $\mathrm{Fe}$ concentrations in the interval from 4 to $16 \mathrm{ft}$ range from 2,067 to $5,200 \mathrm{mg} / \mathrm{kg}$. From 16 to $18 \mathrm{ft}$, the concentration increased to $16,675 \mathrm{mg} / \mathrm{kg}$. This behavior again reflects a change in the stratigraphy, involving a decrease in gypsum content and increase in clay content of site sediments.

Total organic carbon concentrations for site sediment samples varied greatly, and no apparent trends with depth were observed (see Table 4.1). However, the organic carbon levels of the soil are generally low and mostly $\leq 0.2 \mathrm{wt} \%$. This is consistent with the overall oxidized character of the soil. 


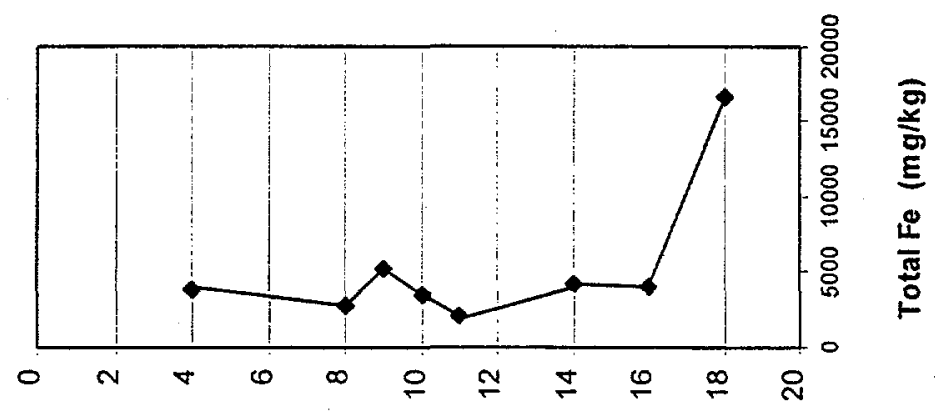

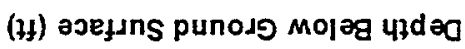

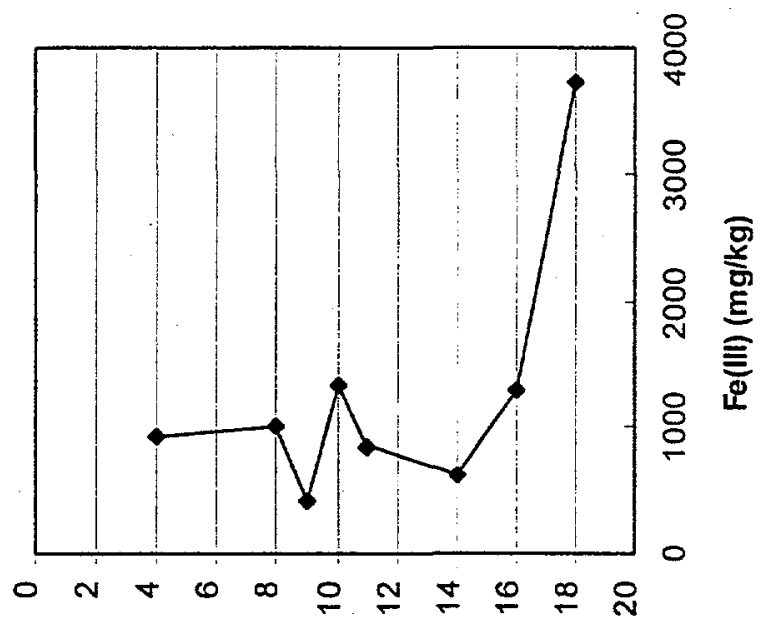

(अ) әsejuns punox Moləg updod

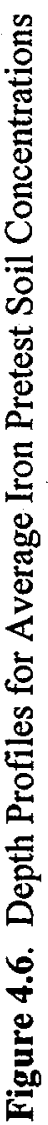

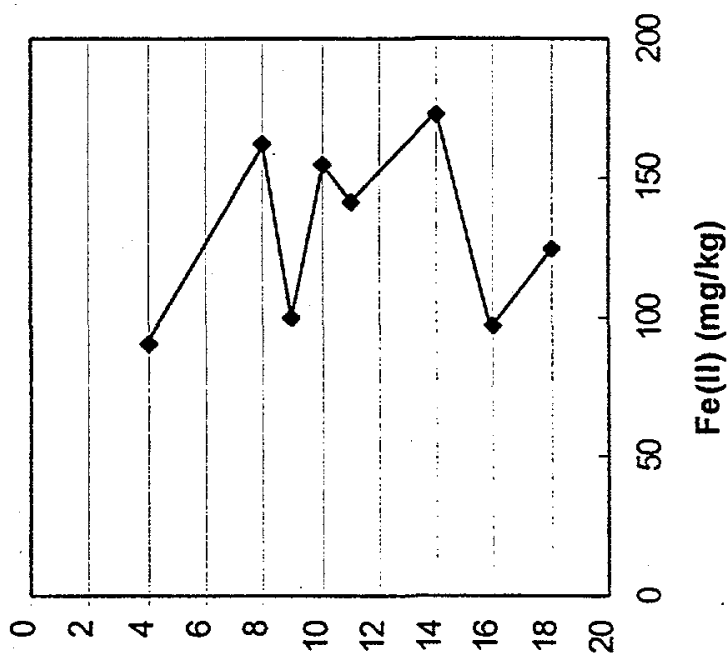

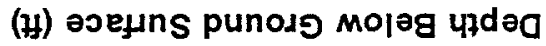




\subsection{Air Permeability. Test}

An air permeability test was conducted on August 22 and 23, 1998 after installation of IGRS-1, soilgas points, and Hypolon cover. ${ }^{1}$ The objective of this test was to measure drawdown of soil-gas pressure at the soil-gas points as a vacuum was applied to IGRS-1. This provided data that were used to estimate the gas permeability of the soils. The depths of the soil points and their relationships to site stratigraphy are presented in Figure 4.7.

A 3-hp regenerative blower powered by a $15-\mathrm{kW}$ diesel-powered portable generator was used during the test. A preliminary test was run on August 22, 1998 for 40 min. A longer test was run on August 23 (390 min total duration) but the blower experienced heating during the test and the data beyond $\sim 80 \mathrm{~min}$ are somewhat suspect. Furthermore, the soil-gas pressures approached steady-state values in $<40 \mathrm{~min}$. Therefore, only the data up to $40 \mathrm{~min}$ have been used in the analysis presented below.

A vacuum of $-80 \mathrm{in}$. of water was applied at IGRS-1 during the test, and a flow of $\sim 5.7 \mathrm{ft}^{3} / \mathrm{min}$ was maintained. Pressure-drawdown data at soil points are presented in Table 4.3 as a function of time. These data were analyzed by the method presented in Johnson et al. (1990), where flow rate and transient pressure distribution are used to estimate soil permeability to airflow. This method involves plotting pressure measurements, $P^{\prime}$ versus $\ln (t)$, which results in a straight line with slope $A$. This slope is related to permeability as expressed by the following:

$$
\mathrm{A}=\frac{\mathrm{Q}}{4 \pi \mathrm{m}(\mathrm{k} / \mu)}
$$

where: $\mathrm{P}$ ' = "gauge" pressure measured at distance, $\mathrm{r}$, and time, $\mathrm{t}(\mathrm{s})$

$\mathrm{Q}=$ volumetric flow rate $\left(5.7 \mathrm{ft}^{3} / \mathrm{min}\right)$

$\mathrm{m}=$ stratum thickness ( $15 \mathrm{ft}$, screened interval)

$\mathrm{k}=$ soil permeability to airflow $\left(\mathrm{cm}^{2}\right)$

$\mu=$ viscosity of air $\left(1.8 \times 10^{-4} \mathrm{~g} / \mathrm{cm}-\mathrm{s}\right)$.

Estimated permeabilities (expressed as darcies) are presented in Table 4.4 for the individual soil points. Permeability values averaged $\sim 60$ darcies, but most values are only estimates. However, data for soil-gas points M6-1, M7-1, and M7-2 are sufficient to provide better values, as evidenced by good correlation coefficients on the plot of $\mathrm{P}^{\prime}$ versus $\ln (\mathrm{t})$. In particular, $\mathrm{M} 7-1$ indicated a permeability of 56 darcies for the white sand and M7-2 indicated 28 darcies for the brown sand. The lower estimated permeability of the brown sand is consistent with a finer grain size and higher clay content.

The air permeabilities obtained from the test were significantly higher than observed in laboratory tests (i.e., 28 to 56 darcies versus 3.6 darcies). This may be related to differences in scale (i.e.,

\footnotetext{
${ }^{1}$ Marozas, DC. 1996. Air permeability test - White Sands Missile Range SWMU. Sandia National Laboratories, Albuquerque, New Mexico.
} 


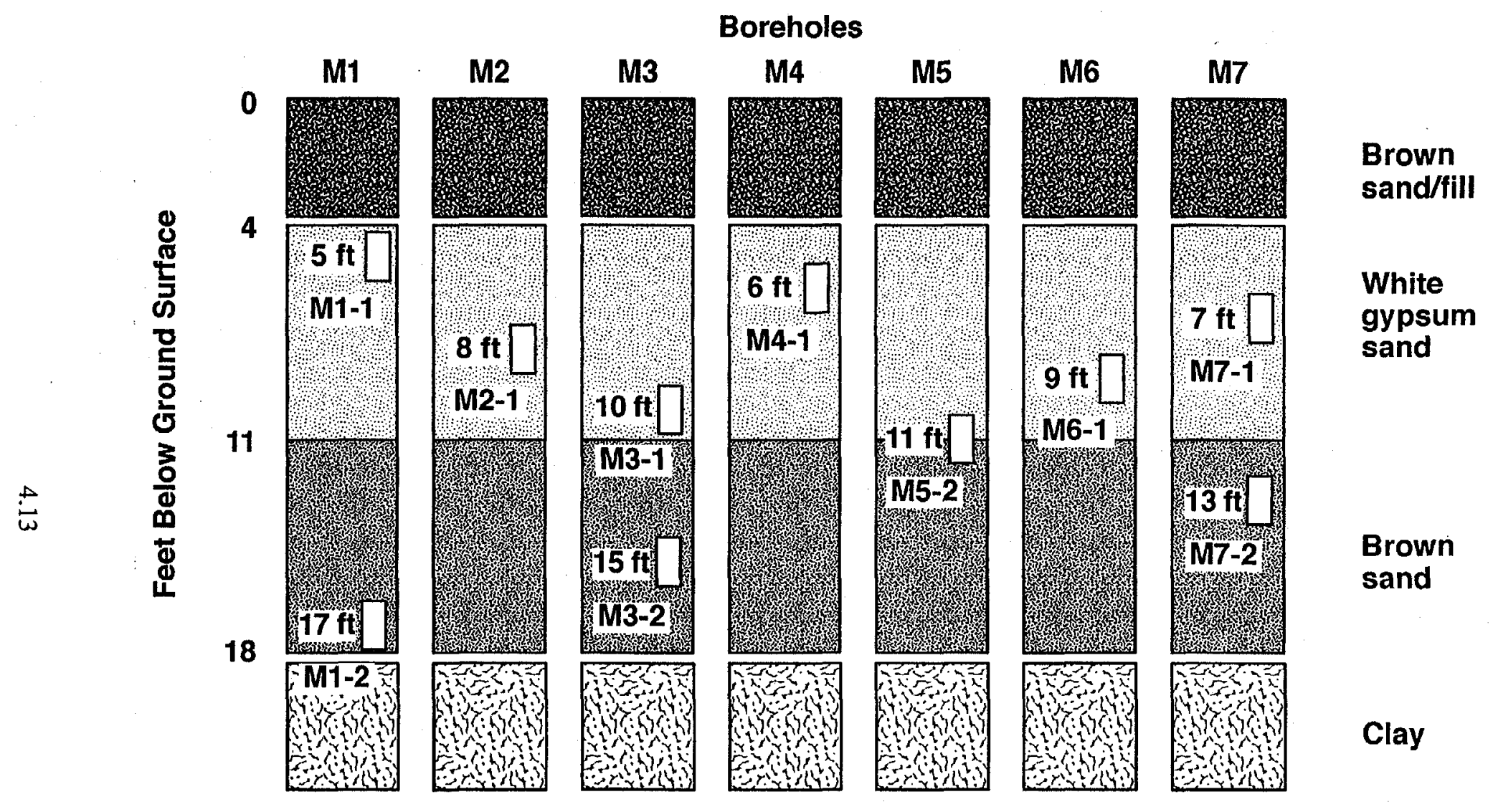

"Depths shown on log are approximate locations of soil gas points.

Figure 4.7. Installation Depths of Soil-Gas Points 
Table 4.3. Air Permeability Test Data

\begin{tabular}{|c|c|c|c|c|c|c|c|c|c|c||}
\hline \multirow{2}{*}{ Time (min) } & \multicolumn{10}{|c||}{ Vacuum (in. of water) } \\
\cline { 2 - 14 } & $1-1$ & $1-2$ & $2-1$ & $3-1$ & $3-2$ & $4-1$ & $5-1$ & $6-1$ & $7-1$ & $7-2$ \\
\hline \hline 0 & 0 & 0 & 0 & 0 & 0 & 0 & 0 & 0 & -0.1 & -0.5 \\
\hline 13 & -0.05 & -0.1 & 0 & 0 & 0 & 0 & 0 & -0.05 & -0.2 & -0.6 \\
\hline 25 & -0.05 & -0.1 & 0 & 0 & 0 & 0 & 0 & -0.1 & -0.25 & -0.8 \\
\hline 40 & -0.05 & -0.1 & -0.1 & 0 & 0 & 0 & 0 & -0.1 & -0.25 & -0.8 \\
\hline
\end{tabular}

Table 4.4. Permeability Estimates Based on Test Measurements

\begin{tabular}{|c|c|c|c|c|}
\hline Monitoring Point & Radial Distance (ft) & $\begin{array}{c}\text { Depth } \\
\text { (ft) }\end{array}$ & $\begin{array}{c}\text { Steady-State Vacuum } \\
\text { (in. of water) }\end{array}$ & Darcies (k) \\
\hline \hline M1-1 & 7.5 & $5(\mathrm{w})$ & -0.05 & $\sim 60$ \\
\hline M1-2 & 7.5 & $17(\mathrm{~b})$ & -0.10 & 83 \\
\hline M2-1 & 7.5 & $8(\mathrm{w})$ & -0.05 & $\sim 60$ \\
\hline M3-1 & 15 & $10(\mathrm{w})$ & -0.05 & $\sim 60$ \\
\hline M3-2 & 15 & $15(\mathrm{~b})$ & -0.05 & $\sim 60$ \\
\hline M4-1 & 15 & $6(\mathrm{w})$ & -0.05 & $\sim 60$ \\
\hline M5-1 & 20 & $11(\mathrm{~b})$ & -0.05 & $\sim 60$ \\
\hline M6-1 & 25 & $9(\mathrm{w})$ & -0.10 & 83 \\
\hline M7-1 & 7.5 & $7(\mathrm{w})$ & -0.25 & 56 \\
\hline M7-2 & 7.5 & $13(\mathrm{~b})$ & -0.80 & 28 \\
\hline (a) $w=$ monitoring gas point positioned in white sand; b point positioned in brown sand. \\
\hline \multicolumn{4}{|r}{} \\
\hline
\end{tabular}

permeability is commonly observed to be higher at the field scale compared to the laboratory scale). This is often attributable to larger-scale structural features present in the field, such as fractures or preferential flow paths.

Steady-state vacuum pressures of the soil points are plotted versus radial distance from IGRS-1 in Figure 4.8 , which indicates that the radius of influence is $\sim 10 \mathrm{ft}$. 


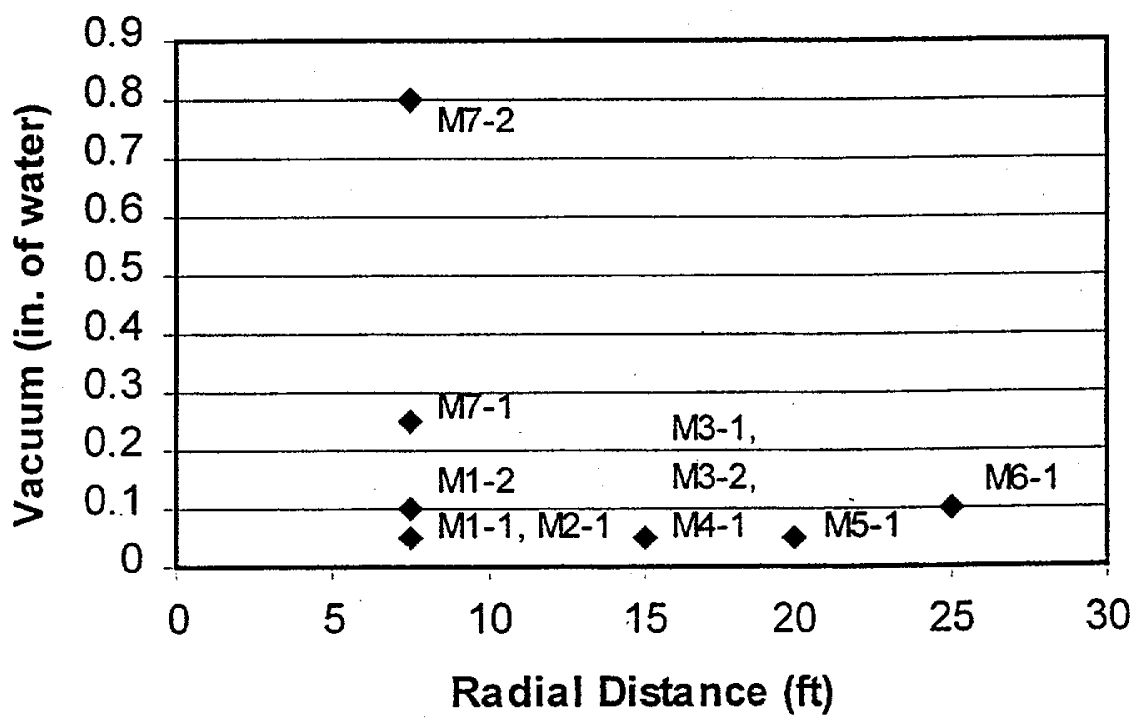

Figure 4.8. Variation of Soil-Gas Point Vacuum Pressures with Radial Distance from IGRS-1 


\subsection{Laboratory Treatability Study}

A laboratory treatability study was conducted to provide design-parameter values needed for the gasinjection test. A composite soil sample collected by auger from a depth of 10 to $14 \mathrm{ft}$ while drilling borehole GP5 was used in this study. Gas treatment of portions of the sample was undertaken in packed columns using $100-\mathrm{ppm}_{\mathrm{v}} \mathrm{H}_{2} \mathrm{~S}$ mixtures. Treatment progress was assessed by monitoring the breakthrough of $\mathrm{H}_{2} \mathrm{~S}$. Evaluation of treatment effectiveness was accomplished by water leaching of untreated and treated soil columns and comparison of the mass recovery of $\mathrm{Cr}(\mathrm{VI})$ in the leachate samples. Breakthrough characteristics were also utilized to provide estimates of expected field treatment time as a function of gas-treatment concentration and flow rate.

\subsection{Column Gas-Treatment Procedure and Breakthrough Characteristics}

Three columns ( 2 -in. inside dia. by $2.9 \mathrm{in}$. long) were packed with homogenized portions of the sediment sample per protocols in WHC (1990). The measured sediment mass and known total volume of the columns, together with estimated particle density $\left(2.8 \mathrm{gm} / \mathrm{cm}^{3}\right)$ and measured moisture content $(30.8 \%)$, were utilized to calculate the pore volume of each column.

Mixtures of $100 \mathrm{ppm}_{\mathrm{v}} \mathrm{H}_{2} \mathrm{~S}$ were prepared (as described in Thornton and Amonette 1997) and directed through two of the columns at a flow rate of $2.5 \mathrm{~L} / \mathrm{min}$ for the duration of each test. In test GP5-14-2, the gas mixture consisted of $100 \mathrm{ppm}_{\mathrm{v}} \mathrm{H}_{2} \mathrm{~S}$ in $\mathrm{N}_{2}$, while in test GP5-14-3, a mixture of $100 \mathrm{ppm}_{\mathrm{v}} \mathrm{H}_{2} \mathrm{~S}$ in air was utilized. One of the soil-packed columns was reserved as an untreated control (test GP5-14-1). All treatment activities involving $\mathrm{H}_{2} \mathrm{~S}$ were conducted in a vented hood because of the toxic nature of the gas. The uncertainty associated with gas-concentration and flow-rate values is estimated to be $\sim 5 \%$.

Electrochemical gas sensors were utilized to measure the $\mathrm{H}_{2} \mathrm{~S}$ concentrations at the inlet and outlet sides of the two treated columns. The inlet concentration was monitored to verify that the treatment-gas concentration was maintained at $100 \mathrm{ppm}_{\mathrm{v}}$, while the outlet concentration was monitored to determine the rate of breakthrough of $\mathrm{H}_{2} \mathrm{~S}$. The accuracy of the sensors was verified using a certified $\mathrm{H}_{2} \mathrm{~S}$ calibration mixture.

The outlet concentration of $\mathrm{H}_{2} \mathrm{~S}$ for the two treatment tests is presented as breakthrough curves in Figures 5:1 and 5.2. Both columns were treated until a ratio of $C / C_{0}>0.8$ was attained to ensure that a high level of reduction of $\mathrm{Cr}(\mathrm{VI})$ in the sediment occurred. At the end of the gas-treatment stage, excess $\mathrm{H}_{2} \mathrm{~S}$ was purged from the columns with $\mathrm{N}_{2}$ or air. Essentially complete purging occurred within $\sim 10 \mathrm{~min}$ (see Figures 5.1 and 5.2). 


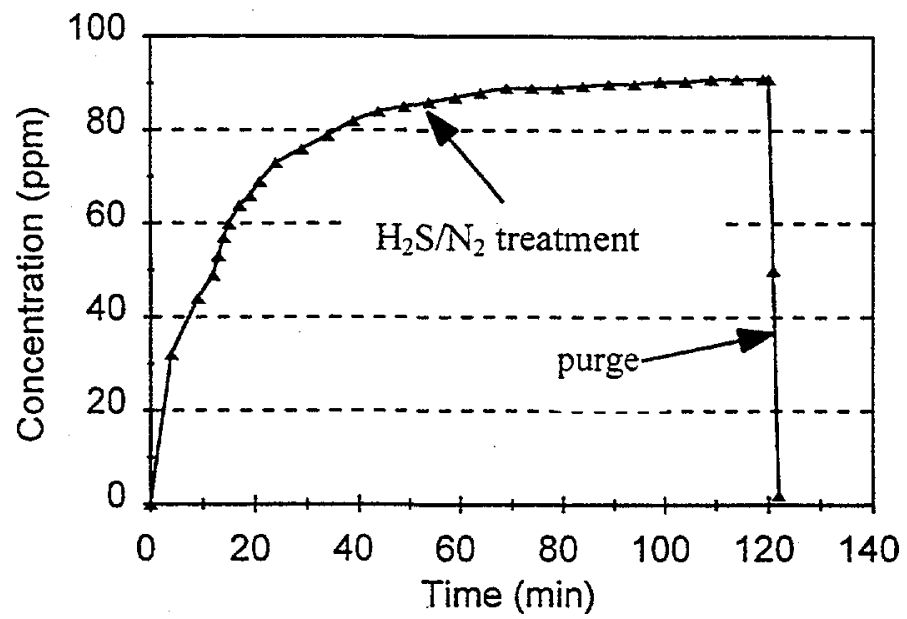

Figure 5.1. Hydrogen Sulfide Breakthrough Curve for Test GP5-14-2

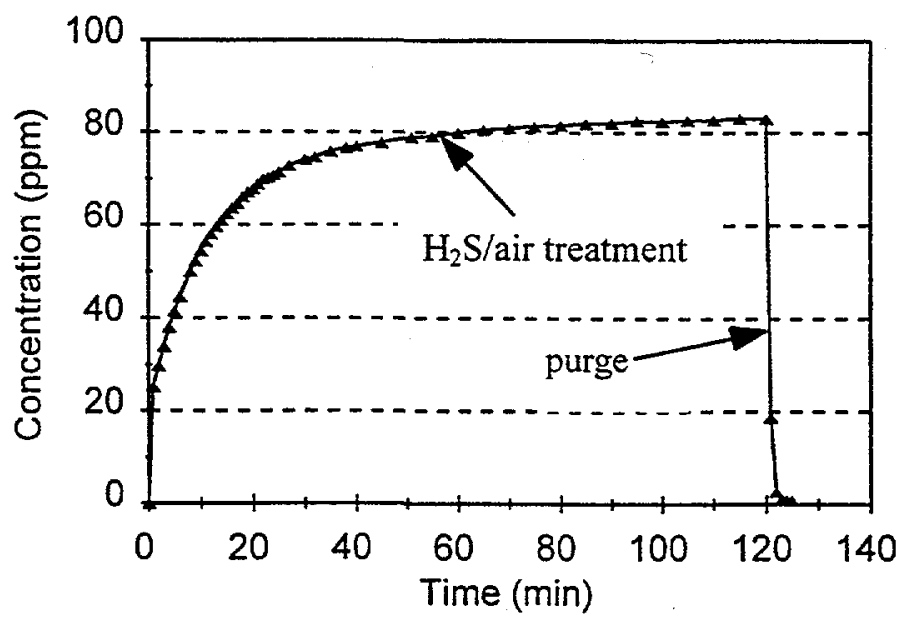

Figure 5.2. Hydrogen Sulfide Breakthrough Curve for Test GP5-14-3

\subsection{Column Leach Procedure and Analysis of Leachate Solutions}

The two treated columns and the untreated control column were leached with deionized water at a flow rate of $\sim 1$ pore volume/day $(\sim 90 \mathrm{~mL} / \mathrm{d})$ using a peristaltic pump. Seven leachate samples were collected per test over a period of a week. Each leachate sample was weighed, and the number of columnpore volumes of water passed through the column was determined. The samples were filtered by a finemeshed screen positioned inside the columns, and no visual evidence of particulate matter was observed in any of the leachate samples.

The leachate samples were analyzed for $\mathrm{Cr}(\mathrm{VI})$, using reagent-grade chemicals and standards. $\mathrm{Cr}$ (VI) concentrations were measured with a spectrophotometer, using the diphenylcarbazide method (Method 
7196, EPA 1992). A detection level of $0.05 \mathrm{ppm}$ or better was attained. Selected samples were analyzed in duplicate to verify acceptable analytical precision. The concentration of $\mathrm{Cr}(\mathrm{VI})$ in the leachate samples is presented in Figures 5.3 and 5.4, where $\mathrm{Cr}(\mathrm{VI})$ is plotted against the number of column-pore volumes associated with each leachate sample. Note that essentially all of the $\mathrm{Cr}(\mathrm{VI})$ in the treated columns was immobilized relative to the untreated control.

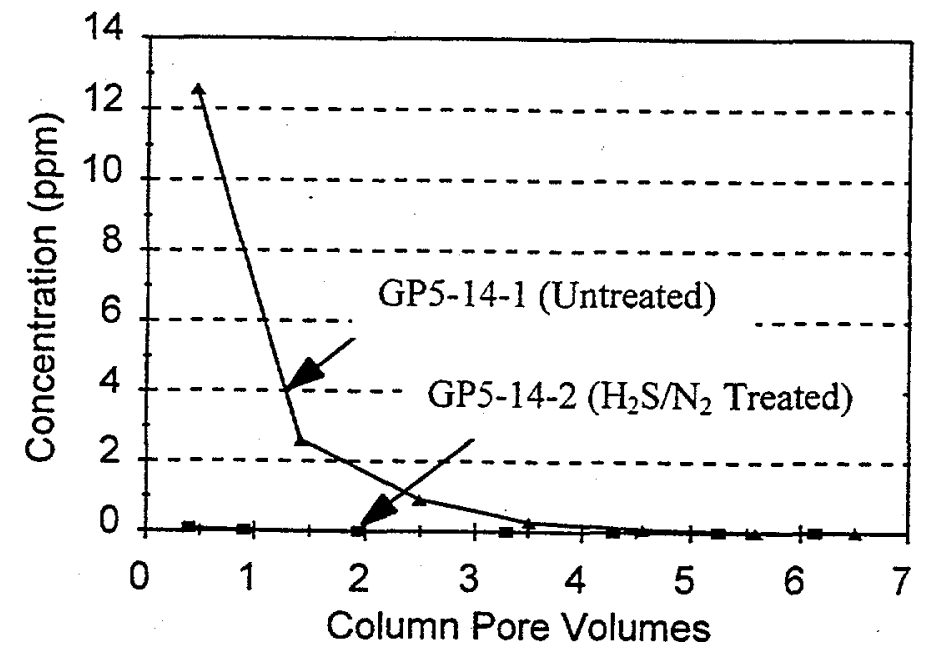

Figure 5.3. Hexavalent Chromium Concentrations of Column Leachate Samples for Tests GP5-14-1 and GP5-14-2

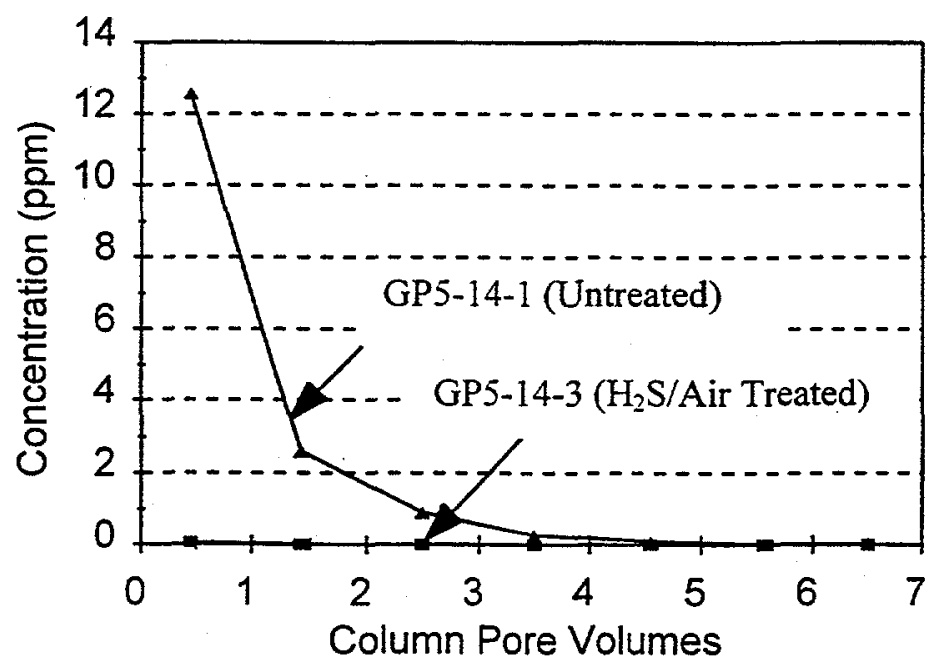

Figure 5.4. Hexavalent Chromium Concentrations of Column Leachate Samples for Tests GP5-14-1 and GP5-14-3 
Solution $\mathrm{pH}$ measurements were also performed on the leachate samples using a standardized $\mathrm{pH}$ electrode judged to be accurate to \pm 0.05 . The measured $\mathrm{pH}$ values ranged from 7.17 to 8.14 ( 7.8 to 8.1 in 27 out of a total of 28 determinations). No significant difference in $\mathrm{pH}$ was identified for the untreated control versus the treated leachate samples.

\subsection{Discussion}

A quantitative assessment of treatment effectiveness can be obtained by comparing the mass recovery of $\mathrm{Cr}(\mathrm{VI})$ in the leachate samples of the treated columns versus the untreated control (Thornton and Amonette 1997). For the untreated control (test GP5-14-1), $1.3192 \mathrm{mg}$ of Cr(VI) were leached from $194.94 \mathrm{~g}$ of sediment, indicating a concentration of $6.8 \mathrm{mg} / \mathrm{kg}$ of $\mathrm{Cr}(\mathrm{VI})$ in the untreated sediment. In test GP5-14-2 $\left(\mathrm{H}_{2} \mathrm{~S} / \mathrm{N}_{2}\right.$-treated sediment), $0.0076 \mathrm{mg}$ of $\mathrm{Cr}$ (VI) was recovered by leaching $190.93 \mathrm{~g}$ of sediment, indicating a recovery of $0.59 \%$ or immobilization by reduction of $\sim 99.4 \% \mathrm{Cr}$ (VI) in the sediment. In test GP5-14-3 ( $\mathrm{H}_{2}$ S/air-treated sediment), $0.0056 \mathrm{mg}$ of $\mathrm{Cr}$ (VI) was recovered by leaching $191.41 \mathrm{~g}$ of sediment, indicating a recovery of $0.43 \%$ or immobilization by reduction of $\sim 99.6 \%$ of the $\mathrm{Cr}(\mathrm{VI})$ in the sediment.

The $\mathrm{H}_{2} \mathrm{~S}$ breakthrough data for the two treated columns provide a means for estimating the amount of treatment gas required to treat a unit mass of soil. Greater than $99 \%$ immobilization was achieved in the two laboratory tests, but these tests were continued to high-breakthrough concentrations $\left(\mathrm{C} / \mathrm{C}_{0}>0.8\right)$. It is expected, however, that at least $90 \%$ immobilization could be achieved if gas treatment were terminated at a $\mathrm{C} / \mathrm{C}_{\mathrm{o}}$ value of 0.7 (Thornton and Amonette 1997). In test GP5-14-2, which involved treatment of the soil with $100 \mathrm{ppm}_{\mathrm{v}} \mathrm{H}_{2} \mathrm{~S}$ in $\mathrm{N}_{2}$ at a flow rate of $2.5 \mathrm{~L} / \mathrm{min}$, it took $22 \mathrm{~min}$ to achieve $70 \%$ breakthrough of $\mathrm{H}_{2} \mathrm{~S}$. This corresponds to the application of $0.000040 \mathrm{lb}$ of $\mathrm{H}_{2} \mathrm{~S}$ to treat $1 \mathrm{lb}$ of contaminated soil. Similarly, test GP5-14-3 suggests that $0.000042 \mathrm{lb}$ of $\mathrm{H}_{2} \mathrm{~S}$ diluted to a concentration of $100 \mathrm{ppm}_{\mathrm{v}}$ in air would be adequate to treat $1 \mathrm{lb}$ of the site soil.

The time required to achieve treatment during the demonstration can be estimated by considering the mass of soil associated with the waste site, the mass of $\mathrm{H}_{2} \mathrm{~S}$ required per unit mass of soil, and the rate of application of $\mathrm{H}_{2} \mathrm{~S}$ to the site. Because the zone targeted for treatment is $15 \mathrm{ft}$ thick and $30 \mathrm{ft}$ in diameter, the volume of soil is $10,603 \mathrm{ft}^{3}$. Based on a measured bulk density of $86.2 \mathrm{lb} / \mathrm{ft}^{3}$ associated with the packed columns of the laboratory treatability tests, $\sim 9.14 \times E 05 \mathrm{lb}$ of soil are located in the target interval. Approximately $36.5 \mathrm{lb}$ of $\mathrm{H}_{2} \mathrm{~S}$ would be required to treat this mass of soil if $0.00004 \mathrm{lb}$ of $\mathrm{H}_{2} \mathrm{~S}$ were applied to each pound of site soil. If the treatment gas is injected into the site as a $100-\mathrm{ppm}_{\mathrm{v}} \mathrm{H}_{2} \mathrm{~S}$ mixture at a flow rate of $100 \mathrm{ft}^{3} / \mathrm{min}$, the time required to achieve a breakthrough $\mathrm{C} / \mathrm{C}_{0}$ value of 0.7 is $\sim 28.7$ days (neglecting field dilutional effects). However, because the treatment time required is inversely proportional to the gas concentration and flow rate, the time associated with treatment can be reduced by increasing the $\mathrm{H}_{2} \mathrm{~S}$ concentration of the injected gas stream or by injecting at a higher flow rate. The relationship between treatment time and gas concentration or flow rate is presented in Figure 5.5. This diagram illustrates, for example, that treatment could be accomplished in $\sim 2$ weeks by injecting 200 ppm $_{\mathrm{v}}$ $\mathrm{H}_{2} \mathrm{~S}$ at a flow rate of $100 \mathrm{ft}^{3} / \mathrm{min}$ or by injecting $400 \mathrm{ppm}_{\mathrm{v}} \mathrm{H}_{2} \mathrm{~S}$ at a flow rate of $60 \mathrm{ft}^{3} / \mathrm{min}$. 


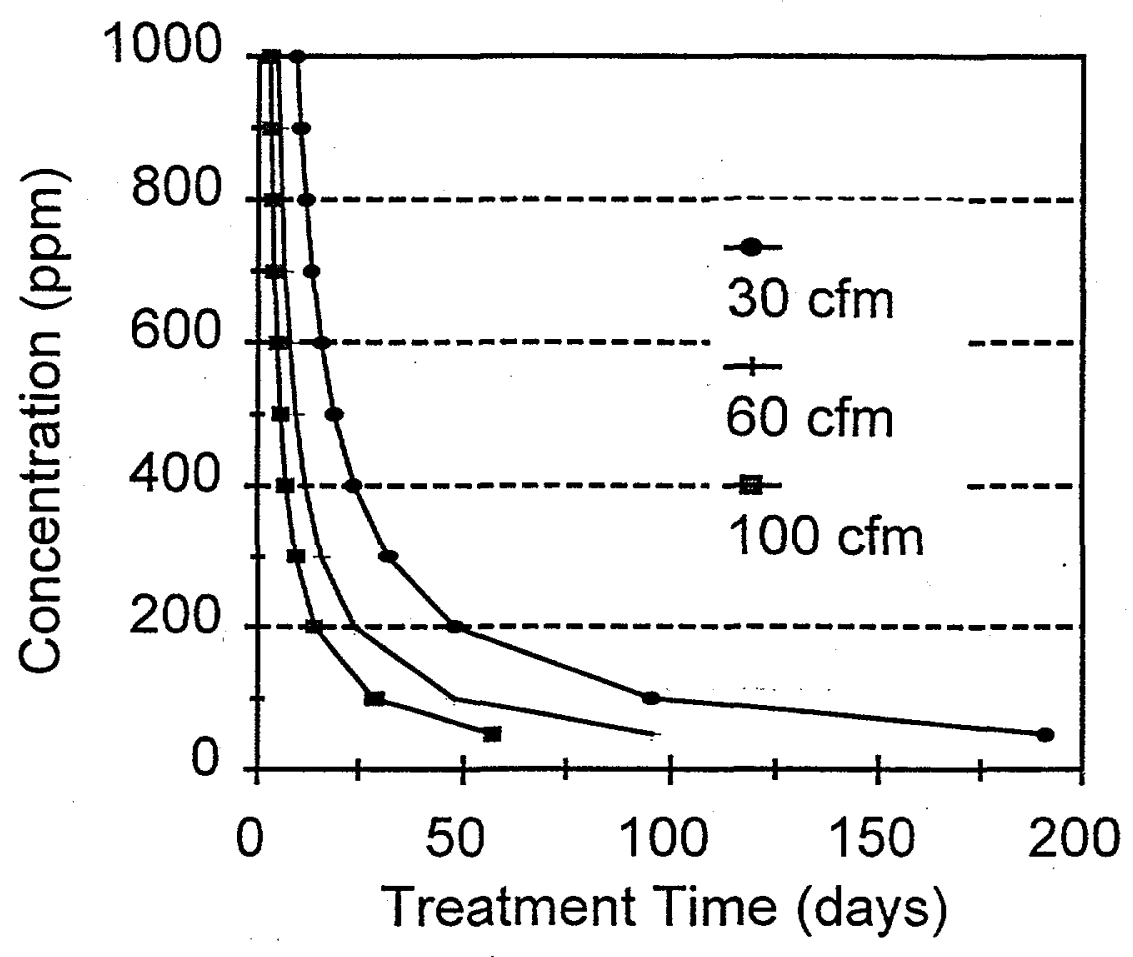

Figure 5.5. Hydrogen Sulfide Concentrations Versus Treatment Times at Various Gas-Flow Rates

It was proposed that a gas concentration of $200 \mathrm{ppm}_{\mathrm{v}} \mathrm{H}_{2} \mathrm{~S}$ be applied at a flow rate of $\sim 30 \mathrm{ft}^{3} / \mathrm{min}$ during the demonstration. For these conditions, the treatment time required should be $\sim 48$ days. Taking dilutional effects within the well field into consideration, a maximum treatment time of 8 weeks is probably adequate to attain a $\mathrm{C} / \mathrm{C}_{0}$ ratio of 0.4 for all of the extraction wells. 


\subsection{Tracer Test}

A gas-tracer test was conducted during September 1997 at SWMU 143. The primary objective of this test was to provide information related to gas-flow characteristics within the test site soil and to determine if the treatment gas can be injected into the site and recovered without significant releases to the site environment. ${ }^{1}$ The tracer test involved injecting sulfur hexafluoride $\left(\mathrm{SF}_{6}\right)$ diluted in air into the site soil and monitoring of gas concentrations within the well-field extraction wells and the site atmosphere. General performance of a prototype gas-treatment system was also monitored during the tracer test. ${ }^{2}$

$\mathrm{SF}_{6}$ is a nontoxic gas with a National Institute for Occupational Safety and Health and Occupational Safety and Health Administration permissible exposure limit of $1,000 \mathrm{ppm}_{\mathrm{v}}$ and has no known adverse effects on the environment. A concentration of $400 \mathrm{ppm}_{\mathrm{v}}$ was utilized in the injection test to ensure that the permissible exposure limit was not exceeded. The conservative, nonreactive character of $\mathrm{SF}_{6}$ makes it useful as a tracer, in that its movement through the soil reflects flow characteristics unaffected by chemical interactions. It can also be detected at very low concentration levels and, thus, is measurable at high dilutions. For these reasons, it is widely used as a gas tracer in field investigations. The ultimate fate of $\mathrm{SF}_{6}$ during the tracer test was release to the atmosphere, where it was subsequently removed from the site by dilution and dispersion.

\subsection{Test Description and Methods}

The prototype gas-treatment system was transported to the test site and used during the tracer test to dilute concentrated $\mathrm{SF}_{6}$ with air, inject the gas mixture into the site soils via the central well, and then remove the mixture via the extraction wells. The configuration of the treatment system and well field was presented in Figure 2.3. Also shown in Figures 2.3 and 4.1 are the locations of the soil-gas points used to obtain additional pressure data during the tracer test. The gas-treatment system is instrumented to measure flow rates, injection and extraction pressures, and temperature of the injection and extraction gas streams. ${ }^{2}$

A perched aquifer is associated with the top of the clay layer ( $20 \mathrm{ft}$ below ground surface). Water levels in the boreholes were measured prior to the tracer test, and it was determined that the depth of water was $\sim 18 \mathrm{ft}$ below ground surface. However, the slotted interval in the wells is from 3 to $18 \mathrm{ft}$ below ground surface; thus, water was not expected to interfere significantly with gas flow during the test. Therefore, it was deemed that the addition of sand or grout to the bottom of the boreholes was not necessary when the injection and extraction wells were installed.

\footnotetext{
${ }^{1}$ Thornton, EC, and J Julya. 1997. IGRS tracer test plan. Pacific Northwest National Laboratory, Richland, Washington.

${ }^{2}$ Duchsherer, M. 1996. In-situ $\mathrm{H}_{2} \mathrm{~S}$ vapor injection/extraction skid operation manual. Westinghouse Hanford Company, Richland, Washington.
} 
An impermeable cover (35- by $35-\mathrm{ft}$ sheet of Hypolon) was placed over the site soil to minimize vertical release of gas and maximize horizontal flow across the network. The cover was sealed at the contacts with the well casings to prevent leakage of gas during the tracer test.

During the tracer test, gas samples were collected in Tedlar ${ }^{\mathrm{TM}}$ bags from the well-field network and site atmosphere using a gas-sampling pump. ${ }^{1}$ Analysis of the samples for $\mathrm{SF}_{6}$ were performed in the field using a portable gas chromatograph equipped with a flame photometric detector (GS/FPD) and involved use of an injection valve and $2-\mathrm{mL}$ sample loop. The instrument was calibrated in the field using a series of 9 standards, ranging from 4.8 to $500 \mathrm{ppm}_{\mathrm{v}} \mathrm{SF}_{6}$ and checked during the course of the day by periodically injecting and analyzing standards. Samples were also periodically reanalyzed to assess reproducibility ( $10 \%$ or less deviation in the range from 50 to $500 \mathrm{ppm}_{\mathrm{v}}$ ). Instrument-detection limit in the field was estimated to be $\sim 10 \mathrm{ppm}_{\mathrm{v}} \mathrm{SF}_{6}$ because of high noise to signal ratio.

Gas samples stored in Tedlar ${ }^{\mathrm{TM}}$ bags were shipped to Pacific Northwest National Laboratory for $\mathrm{SF}_{6}$ analysis by a gas chromatograph equipped with an electron capture detector (GC/ECD). These samples were analyzed according to Pacific Northwest National Laboratory procedures for this method and are judged to have a detection limit of $\sim 0.03 \mathrm{ppb}_{\mathrm{v}}$. Greater than $90 \%$ recovery was maintained, as determined by periodic analysis of check standards. Duplicate analyses of samples indicated good reproducibility ( $\sim 5 \%$ deviation from the mean).

Field screening for $\mathrm{SF}_{6}$ was also performed during the tracer test using a Wilks Miran variable filter infrared analyzer. This approach is semiquantitative in nature, but periodic recalibrations were performed in the field using a check standard. The instrument-detection limit was judged to be $\sim 1 \mathrm{ppm}_{\mathrm{v}}$.

The locations of the gas-treatment system, well-field network, and gas-sampling stations at the time of the tracer test are presented in Figure 6.1. The extracted gas stream was released through an exhaust hose to an offsite point (S-13) to minimize the effect on monitoring activities in the immediate vicinity of the test site. Offsite release of $\mathrm{SF}_{6}$ was necessary because this component cannot be removed by the treatment system gas scrubber.

The first part of the tracer test consisted of a preinjection stage, which began at 8:00 a.m. on September 25,1997 . During this stage, injection and extraction of site air were undertaken using the gas system and well-field network. The objective of this phase was to verify the satisfactory operational status of the gas-treatment system and to establish site and background concentrations of $\mathrm{SF}_{6}$.

Injection and extraction of the tracer gas mixture into site soil via the well-field network were undertaken in the second stage of the test, which began at 12:10 p.m. on September 25, 1997. This was the main phase of the tracer test and was undertaken to provide information related to site gas-flow characteristics. Injection and extraction gas samples were collected and analyzed to determine if preferential flow paths exist within the site and to determine the time required for the flow field to achieve steady state. This information will also provide a basis for evaluating the degree of dilution of the injected gas

\footnotetext{
${ }^{1}$ Thornton, EC, and J Julya. 1997. IGRS tracer test plan. Pacific Northwest National Laboratory, Richland, Washington.
} 
Road

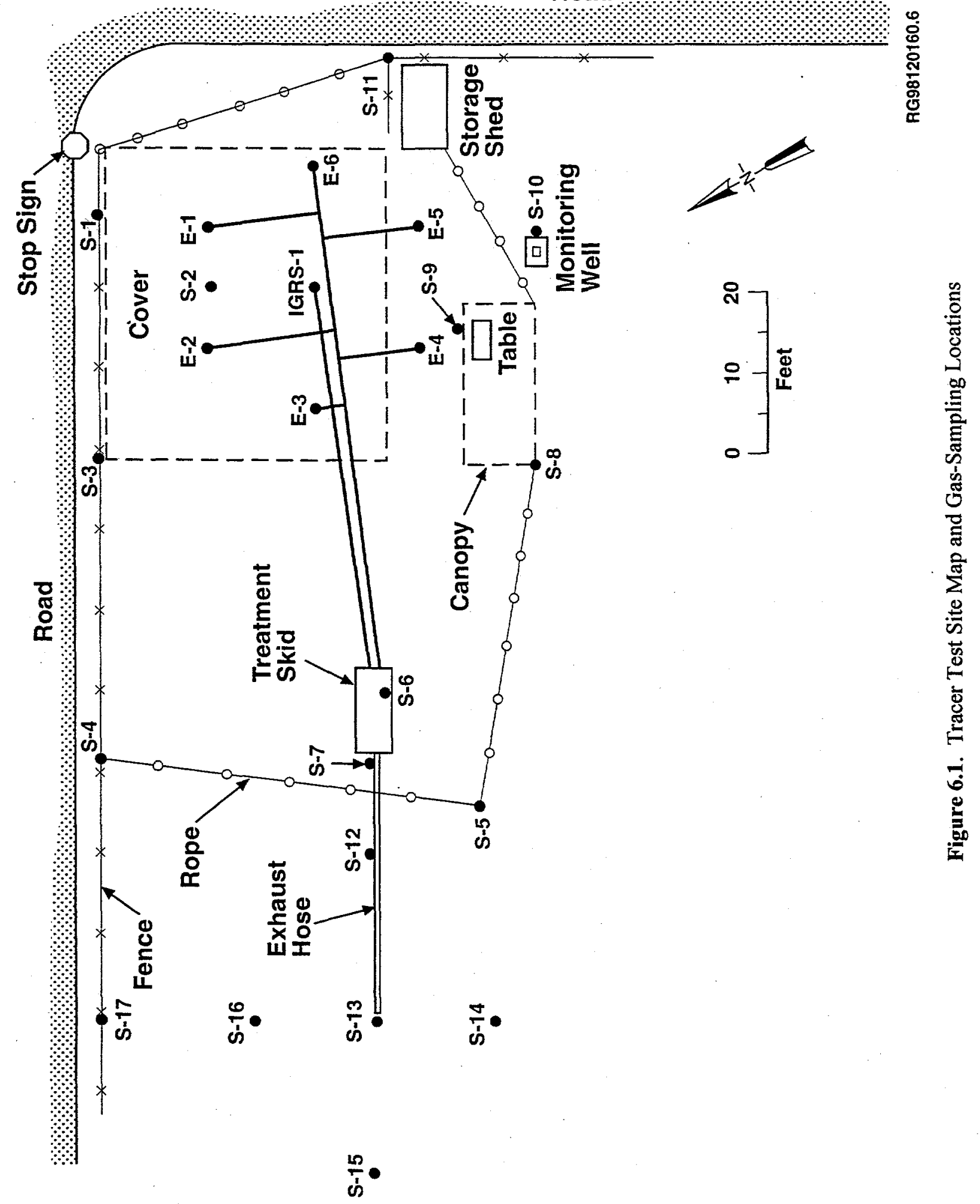


by air drawn into the site by the extraction wells. Well-field flow rates and pressures were also monitored to determine gas-flow characteristics within the site. System operational characteristics were also monitored during this stage to provide a basis for evaluating performance under field conditions.

The final stage of the tracer test involved purging the site of $\mathrm{SF}_{6}$ by injecting air and extracting residual tracer gas from the well field, which was initiated at 1:20 p.m. on September 26, 1997. The objective of this activity was to determine the time required to purge the site of excess tracer gas. This is related to the heterogeneity of site soils (i.e., long-term diffusion of gas into and out of zones of lower permeability) and is a useful means of estimating the amount of time that will be needed to purge the site of $\mathrm{H}_{2} \mathrm{~S}$ at the end of the gas-treatment test. The purge stage of the tracer test was completed at 4:00 p.m. on September 26, 1997. Thus, the system ran continuously for a period of $\sim 32 \mathrm{~h}$ during the tracer test.

\subsection{Results}

The primary tasks undertaken during the tracer test were the collection of treatment-system performance information, well-field gas-flow data, and gas-concentration measurements within the well field and in the site atmosphere. A discussion of these activities is presented below.

\subsubsection{Gas-Treatment System Performance}

The major parts of the tracer test included the preinjection, tracer injection, and purge stages, which involved running the system continuously for $32 \mathrm{~h}$ on September 25 and 26, 1997. During the injection stage, a mixture of $\sim 400 \mathrm{ppm}_{\mathrm{v}} \mathrm{SF}_{6}$ was prepared by the system and pumped into the injection well. The $\mathrm{SF}_{6}$ gas cylinder was turned off at the initiation of the purge stage, when pure air was pumped through the site. System performance was satisfactory during the tracer test, and no major problems were observed. Several system parameters were measured during the tracer test, including pressures, flow rates; and gasstream temperature; all were found to be acceptable and fairly stable.

\subsubsection{Well-Field Pressure and Flow-Rate Data}

Well-field pressure and flow-rate data collected during the tracer test are presented in Table 6.1. The injection flow rate at IGRS-1 was $\sim 20 \mathrm{ft}^{3} / \mathrm{min}$ during the test, while the total extraction flow rate was $\sim 40 \mathrm{ft}^{3} / \mathrm{min}$. Thus, $\sim 50 \%$ dilution of the injected gas with air from outside the network was observed in the extraction wells.

The injection pressure required to maintain a $20-\mathrm{ft}^{3} / \mathrm{min}$ flow rate decreased from $\sim 116$ to $48 \mathrm{in}$. of water on September 25,1997 . The injection pressure was turned down to $\sim 21 \mathrm{in}$. of water on September 26 to maintain $20 \mathrm{ft}^{3} / \mathrm{min}$. The decrease in required injection pressure is attributed to removal of water from the vicinity of the injection borehole by evaporation and downgradient migration with the airflow. 
Table 6.1. Tracer Test Well-Field Pressure and Flow-Rate Data

\begin{tabular}{|c|c|c|c|c|c|c|c|c|c|c|}
\hline \multirow[b]{2}{*}{$\begin{array}{l}\text { Sample } \\
\text { Location }\end{array}$} & \multicolumn{10}{|c|}{ September 25,1997} \\
\hline & $\begin{array}{c}9: 10 \text { a.m. } \\
\text { pressure (in. } \\
\text { of water) }\end{array}$ & $\begin{array}{c}9: 10 \mathrm{a} \cdot \mathrm{m} \\
\text { flow }\left(\mathrm{ft}^{3} / \mathrm{min}\right)\end{array}$ & $\begin{array}{l}\text { 11:01 a.m. } \\
\text { pressure (in. } \\
\text { of water) }\end{array}$ & $\begin{array}{l}\text { 11:01 a.m. } \\
\text { flow }\left(\mathrm{ft}^{3} / \mathrm{min}\right)\end{array}$ & $\begin{array}{l}\text { 1:00 p.m. } \\
\text { pressure (in. } \\
\text { of water) }\end{array}$ & $\begin{array}{c}\text { 1:00.p.m. } \\
\text { flow }\left(\mathrm{f}^{3} / \mathrm{min}\right)\end{array}$ & $\begin{array}{l}2: 25 \text { p.m. } \\
\text { pressure (in. } \\
\text { of water) }\end{array}$ & $\begin{array}{c}2: 25 \mathrm{p} . \mathrm{m} \\
\text { flow }\left(\mathrm{f}^{3} / \mathrm{min}\right)\end{array}$ & $\begin{array}{l}\text { 3:41 p.m. } \\
\text { pressure (in. } \\
\text { of water) }\end{array}$ & $\begin{array}{c}\text { 3:41 p.m. } \\
\text { flow }\left(\mathrm{f}^{3} / \mathrm{min}\right)\end{array}$ \\
\hline IGRS-1 & +116 & 16 & +105 & 22 & +108 & 22 & +48 & 20 & +49 & 20 \\
\hline E-1 & -21 & 8 & -20 & 7.5 & -20 & 7.5 & -20 & 7.5 & -20 & 7.5 \\
\hline E-2 & -50 & 5.5 & -48 & 5 & -48 & 5.5 & -48 & 5 & -48 & 4.5 \\
\hline E-3 & -50 & 3 & -49 & 4 & -48 & 4 & -48 & 3.5 & -48 & 4 \\
\hline E-4 & -32 & 8 & -30 & 7.5 & -29 & 7.5 & -29 & 7.5 & -29 & 7.5 \\
\hline E-5 & -37 & 8 & -35 & 7.5 & -35 & 7.5 & -35 & 7.5 & -35 & 7.5 \\
\hline E-6 & -51 & 6 & -50 & 6 & -50 & 6 & -50 & 6 & -50 & 6 \\
\hline $\mathrm{M} 1-1(5)^{(a)}$ & -- & & -0.0 & & -0.01 & & -0.03 & & -0.25 & \\
\hline M1-2(17) & -- & & +0.055 & & +0.01 & & -0.02 & & -0.02 & \\
\hline M2-1 (8) & - & & +0.04 & & +0.05 & & +0.035 & & +0.052 & \\
\hline M3-1 (10) & $\cdots$ & & .0 .03 & & -0.03 & & -0.035 & & -0.030 & \\
\hline M3-2 (15) & -- & & -0.08 & & -0.05 & & -0.055 & & -0.045 & \\
\hline M4-1 (6) & -- & & -0.33 & & -0.27 & & -0.28 & & -0.28 & \\
\hline M5-1 (11) & -- & & -0.035 & & -0.030 & & -0.03 & & -0.005 & \\
\hline M6-1 (9) & -- & & -0.0005 & & -0.0 & & -0.01 & & +0.005 & \\
\hline M7-1 (7) & -- & & -0.38 & & -0.44 & & -0.48 & & -0.42 & \\
\hline M7-2 (13) & -- & & -0.96 & . & -1.0 & & $\begin{array}{c}<-1.0 \\
\text { (off scale) }\end{array}$ & & $\begin{array}{c}<-1.0 \\
\text { (off scale) }\end{array}$ & \\
\hline
\end{tabular}


Table 6.1. (contd)

\begin{tabular}{|c|c|c|c|c|c|c|c|c|c|c|}
\hline \multirow[b]{2}{*}{$\begin{array}{l}\text { Sample } \\
\text { Location }\end{array}$} & \multicolumn{10}{|c|}{ September 26, 1997} \\
\hline & $\begin{array}{c}\text { 8:30 a.m. } \\
\text { pressure (in. } \\
\text { of water) }\end{array}$ & $\begin{array}{c}8: 30 \mathrm{am} . \\
\text { flow }\left(\mathrm{ft}^{3} / \mathrm{min}\right)\end{array}$ & $\begin{array}{c}8: 53 \text { a.m. } \\
\text { pressure (in. } \\
\text { of water) }\end{array}$ & $\begin{array}{c}\text { 8:53 a.m. } \\
\text { flow }\left(\mathrm{ft}^{3} / \mathrm{min}\right)\end{array}$ & $\begin{array}{c}\text { 10:53 a.m. } \\
\text { pressure (in. } \\
\text { of water) }\end{array}$ & $\begin{array}{c}\text { 10:53 a.m. } \\
\text { flow }\left(\mathrm{ft}^{3} / \mathrm{min}\right)\end{array}$ & $\begin{array}{c}12: 50 \text { p.m. } \\
\text { pressure (in. } \\
\text { of water) }\end{array}$ & $\begin{array}{c}12: 50 \text { p.m. } \\
\text { flow }\left(\mathrm{ft}^{3} / \mathrm{min}\right)\end{array}$ & $\begin{array}{c}\text { 3:00 p.m. } \\
\text { pressure (in. } \\
\text { of water) }\end{array}$ & $\begin{array}{c}\text { 3:00 p.m. } \\
\text { flow }\left(\mathrm{f}^{3} / \mathrm{min}\right)\end{array}$ \\
\hline IGRS-1 & +21 & 20 & +21 & 21 & +21 & 22 & +20 & 22 & +94 & 78 \\
\hline E-1 & -21 & 8 & -21 & 8 & -21 & 8 & -21 & 7.5 & - & 8.5 \\
\hline E-2 & -44 & 6 & -48 & 6 & -48 & 5.5 & -47 & 5 & -- & 6 \\
\hline E-3 & -48 & 4 & -48 & 4 & -48 & 3.5 & -47 & 3.5 & -. & 5 \\
\hline E-4 & -20 & 9 & -20 & 9 & .20 & 9 & -21 & 8.5 & -24 & 10 \\
\hline E-5 & -31 & 9 & -32 & 9 & -31 & 9 & -31 & 8.5 & .36 & 10 \\
\hline E-6 & -50 & 6 & -50 & 6.5 & -50 & 5.5 & -50 & 5.5 & .63 & 7 \\
\hline$M 1-1(5)^{(a)}$ & -0.055 & & -0.06 & & -0.07 & & -0.071 & & $-\cdot$ & \\
\hline M1-2 (17) & -0.041 & & -0.035 & & -0.045 & & -0.052 & & -- & \\
\hline M2-1 (8) & +0.099 & & +0.095 & & +0.11 & & +0.122 & & - & \\
\hline M3-1 (10) & -0.019 & & -0.025 & & -0.02 & & -0.019 & & -. & \\
\hline M3-2 (15) & -0.045 & & -0.05 & & -0.055 & & -0.055 & & -- & \\
\hline M4-1 (6) & -0.27 & & -0.28 & & -0.28 & & -0.269 & & - & \\
\hline M5-1 (11) & -0.004 & & -0.005 & & -0.0025 & & 0 & & -- & \\
\hline M6-1 (9) & $<0$ & & +0.005 & & +0.02 & & +0.023 & & -- & \\
\hline M7-1 (7) & -0.44 & & -0.42 & & -0.43 & & -0.42 & & $-\cdot$ & \\
\hline M7-2 (13) & $\begin{array}{c}<-1.0 \\
\text { (off scale) }\end{array}$ & & $\begin{array}{c}<-1.0 \\
\text { (off scale) }\end{array}$ & & $\begin{array}{c}<-1.0 \\
\text { (off scale) }\end{array}$ & & $\begin{array}{c}<-1.0 \\
\text { (off scale) }\end{array}$ & & -. & \\
\hline
\end{tabular}


Individual flow rates for the extraction wells varied from $\sim 4 \mathrm{ft}^{3} / \mathrm{min}$ for $\mathrm{E}-3$ to $9 \mathrm{ft}^{3} / \mathrm{min}$ for $\mathrm{E}-4$ and E-5, suggesting a significant degree of preferential flow. This occurred despite an effort to equalize extraction well-flow rates by adjusting the valves for the individual wells (note applied wellhead extraction pressures in Table 6.1). Extraction flow rates were also found to increase somewhat during the tracer test.

Pressure data were also collected for the seven soil-gas points (see Table 6.1). Negative pressures observed at points M3 (located between E-3 and E-4) and M4 (located between E-1 and E-6) suggest that capture of the injected gas by the extraction network was complete.

Near the end of the test (3:00 p.m. on September 26; see Table 6.1), the throttle valves of the blowers were closed until the pressure-relief valves actuated (which are set at $\sim 5 \mathrm{lb} / \mathrm{in} .{ }^{2} \mathrm{~g}$ ). This was undertaken in an effort to better evaluate maximum injection and extraction flow rates. It was determined that the maximum injection flow rate at IGRS-1 was $\sim 78 \mathrm{ft}^{3} / \mathrm{min}$ and the total extraction flow rate $\sim 46 \mathrm{ft}^{3} / \mathrm{min}$. It was concluded that a maximum injection flow rate of $\sim 23 \mathrm{ft}^{3} / \mathrm{min}$ can be applied with a total extraction flow rate of $46 \mathrm{ft}^{3} / \mathrm{min}$ and still maintain good capture characteristics. Somewhat higher rates could be applied if the pressure-relief valves are set to actuate at higher pressures. Injection and extraction flow rates are also expected to increase with time during the gas-treatment demonstration as a result of removal of water from the soil by evaporation or downgradient migration.

\subsubsection{Monitoring of Well-Field and Background Gas Concentrations}

Measurements of $\mathrm{SF}_{6}$ concentrations were performed for the well field and at site locations during the tracer test (see Figure 6.1). The objectives of this activity were to determine gas-flow patterns and characteristics of the well-field network and the extent of gas emissions to the site environment. Gas concentrations were measured by infrared, GC/FPD, and GC/ECD methods.

The results of field infrared analysis for $\mathrm{SF}_{6}$ are presented in Table 6.2. These measurements were taken at site locations and were at or below the instrument-detection limit $\left(1 \mathrm{ppm}_{\mathrm{v}}\right)$ at all sampling locations, except S-6, S-12, and S-13. S-6 was located at the exit of the throttle valve on the treatment skid injection blower (see Figure 6.1), where measurements suggest that some leakage of $\mathrm{SF}_{6}$ was occurring in conjunction with mixing of air and $\mathrm{SF}_{6}$ in the injection line. This observation indicated that the injection line needed to be modified, with the bleed valve being placed farther upstream from the point where $\mathrm{SF}_{6}$ enters the line. S-12 was located $\sim 20 \mathrm{ft}$ from S-13 and near a joint in the exhaust hose. Concentrations of $\sim 3 \mathrm{ppm}_{\mathrm{v}} \mathrm{SF}_{6}$ were noted at S-12; this can be attributed to leakage of gas at the joint and perhaps also to migration of exhaust gas from S-13. S-13 was located at the end of a hose where the extracted gas/air mixture was exhausted, and measurements indicate the mixture contained $\sim 60 \mathrm{ppm}_{\mathrm{v}} \mathrm{SF}_{6}$ during the injection stage of the tracer test. (Note that the well-field extraction stream was diluted by air drawn in at the bleed valve associated with the extraction blower.)

Measurements of gas samples collected from beneath the edges of the cover were conducted during the test. These measurements were below the detection limit of the infrared instrument $\left(1 \mathrm{ppm}_{\mathrm{v}} \mathrm{SF}_{6}\right)$, suggesting that emission of injection gas from beneath the cover was not significant during the tracer test. 
Table 6.2. Sulfur Hexafluoride Measurements by Infrared Analysis

\begin{tabular}{||l|c|c|c|c|c|c|c||}
\hline \multirow{3}{*}{$\begin{array}{c}\text { Sample } \\
\text { Location }\end{array}$} & $\begin{array}{c}10: 00 \text { a.m. } \\
\left(\mathrm{ppm}_{\mathrm{v}}\right)\end{array}$ & $\begin{array}{c}11: 18 \text { a.m. } \\
\left(\mathrm{ppm}_{\mathrm{v}}\right)\end{array}$ & $\begin{array}{c}1: 16 \mathrm{p.m} . \\
\left(\mathrm{ppm}_{\mathrm{v}}\right)\end{array}$ & $\begin{array}{c}2: 41 \text { p.m. } \\
\left(\mathrm{ppm}_{\mathrm{v}}\right)\end{array}$ & $\begin{array}{c}3: 51 \text { p.m. } \\
\left(\mathrm{ppm}_{\mathrm{v}}\right)\end{array}$ & $\begin{array}{c}9: 10 \text { a.m. } \\
\left(\mathrm{ppm}_{\mathrm{v}}\right)\end{array}$ & $\begin{array}{c}11: 09 \text { a.m. } \\
\left(\mathrm{ppm}_{\mathrm{v}}\right)\end{array}$ \\
\hline \hline S-1 & 0.3 & -- & 0.15 & 0.0 & 0.3 & 0.3 & 0.45 \\
\hline S-2 & 0.0 & -- & 0.8 & 0.15 & 0.15 & 0.15 & 0.3 \\
\hline S-3 & 0.0 & -- & 0.0 & 0.0 & 0.0 & 0.0 & 0.0 \\
\hline S-4 & 0.0 & -- & 0.0 & 0.3 & 0.0 & 0.0 & 0.15 \\
\hline S-5 & 0.0 & 0.0 & 0.0 & 0.15 & 0.0 & 1.5 & 0.3 \\
\hline S-6 & 0.0 & 0.3 & 1.2 & 4.1 & 4.2 & 5.2 & 4.8 \\
\hline S-7 & 0.0 & 0.0 & 0.5 & 0.5 & 0.0 & 1.4 & 1.1 \\
\hline S-8 & 0.0 & 0.0 & 0.3 & 0.0 & 0.0 & 0.5 & 0.9 \\
\hline S-9 & 0.3 & 0.8 & 0.0 & 0.0 & 0.0 & 0.15 & 1.1 \\
\hline S-10 & 0.0 & 0.6 & 0.0 & 0.0 & 0.0 & 0.0 & 0.0 \\
\hline S-11 & 0.16 & 0.3 & 0.15 & 0.0 & 0.15 & 0.3 & 0.3 \\
\hline S-12 & -- & 0.15 & 1.2 & 1.1 & 1.2 & 3.2 & 0.45 \\
\hline S-13 & -- & 0.5 & 56.9 & 56.5 & 65.7 & 55.4 & 63.6 \\
\hline S-14 & -- & -- & 0.0 & 0.15 & 0.3 & 0.8 & 0.8 \\
\hline S-15 & -- & -- & 0.5 & 0.15 & 0.3 & 0.5 & 1.1 \\
\hline S-16 & -- & -- & 0.8 & 0.0 & 1.5 & 0.15 & 0.8 \\
\hline S-17 & -- & -- & 0.5 & 0.15 & 0.0 & 0.3 & 0.45 \\
\hline$--=$ Not measured. & & & & & & \\
\hline \hline
\end{tabular}

However, $\mathrm{SF}_{6}$ was detected near a small hole in the cover in the vicinity of S-2. This observation suggests that accumulation of $\mathrm{SF}_{6}$ beneath the cover in the vicinity of IGRS-1 was occurring during the tracer test.

Measurements of $\mathrm{SF}_{6}$ by GC/FPD were taken primarily in the field, but several measurements were also performed on samples brought back to Pacific Northwest National Laboratory (Table 6.3). The detection limit of the instrument was $\sim 10 \mathrm{ppm}_{\mathrm{v}}$ because of a high noise to signal ratio. Thus, the sensitivity of the instrument was not sufficient for most sample locations but yielded useful data for injection (IGRS-1) and extraction (E-1 through E-6) well samples and for S-13; the end of the exhaust hose (see Figure 6.1). Note that analysis of the injection gas mixture indicates that it contained $\sim 425 \mathrm{ppm}_{\mathrm{v}} \mathrm{SF}_{6}$ on September 25 and $351 \mathrm{ppm}_{\mathrm{V}}$ on September 26 . The $\mathrm{SF}_{6}$ analytical data for E-1 through E-6 suggest that the well-field gas distribution reached steady state within $3 \mathrm{~h}$ after initiating the injection stage of the test on September 25. By the morning of September 26, $\mathrm{SF}_{6}$ concentrations at the extraction wells ranged 
Table 6.3. Sulfur Hexafluoride Measurements by Gas Chromatograph/Flame Photometric Detector

\begin{tabular}{||l|c|c|c|c|c|c|c|c||}
\hline \multirow{3}{*}{$\begin{array}{c}\text { Sample } \\
\text { Location }\end{array}$} & $\begin{array}{c}8: 16 \text { a.m. } \\
\left(\mathrm{ppm}_{\mathrm{v}}\right)\end{array}$ & $\begin{array}{c}11: 01 \text { a.m. } \\
\left(\mathrm{ppm}_{\mathrm{v}}\right)\end{array}$ & $\begin{array}{c}12: 30 \text { p.m. } \\
\left(\mathrm{ppm}_{\mathrm{v}}\right)\end{array}$ & $\begin{array}{c}2: 28 \text { p.m. } \\
\left(\mathrm{ppm}_{\mathrm{v}}\right)\end{array}$ & $\begin{array}{c}4: 00 \text { p.m. } \\
\left(\mathrm{ppm}_{\mathrm{v}}\right)\end{array}$ & $\begin{array}{c}10: 00 \text { a.m. } \\
\left(\mathrm{ppm}_{\mathrm{v}}\right)\end{array}$ & $\begin{array}{c}1: 35 \text { p.m. } \\
\left(\mathrm{ppm}_{\mathrm{v}}\right)\end{array}$ & $\begin{array}{c}2: 10 \text { p.m. } \\
\left(\mathrm{ppm}_{\mathrm{v}}\right)\end{array}$ \\
\hline \hline IGRS-1 & - & $<10$ & 426 & - & 424 & 351 & - & - \\
\hline E-1 & $<10$ & $<10$ & 146 & - & 324 & 237 & 161 & $<10$ \\
\hline E-2 & - & -- & 163 & - & 348 & 148 & -- & - \\
\hline E-3 & $<10$ & $<10$ & 55 & -- & 83 & 150 & -- & - \\
\hline E-4 & - & -- & 69 & - & 195 & 120 & - & - \\
\hline E-5 & -- & -- & 63 & - & 214 & 165 & -- & -- \\
\hline E-6 & -- & -- & 164 & -- & 298 & 204 & -- & -- \\
\hline S-13 & -- & -- & - & 24 & -- & $\leq 20$ & 24 & -- \\
\hline$-=$ - Not measured.
\end{tabular}

from $120 \mathrm{ppm}_{\mathrm{v}}$ for $\mathrm{E}-4$ to $237 \mathrm{ppm}_{\mathrm{v}}$ for E-1, suggesting some degree of preferential flow. These values also indicate that $\sim 50 \%$ dilution of injected gas by inflow from outside the network occurred at the extraction wells. The latter observation agreed with preliminary airflow-modeling activities. ${ }^{1}$

Note that $\mathrm{SF}_{6}$ concentration measurements at location $\mathrm{S}-13$ indicated $\sim 60 \mathrm{ppm}_{\mathrm{v}}$ by infrared analysis but only $24 \mathrm{ppm}_{\mathrm{v}}$ by GC/FPD. This may be attributed to dilution while pumping the sample into the Tedlar $^{\mathrm{TM}}$ bag prior to GC/FPD analysis or possibly to error associated with the GC/FPD analysis at lower levels (detection limit $\sim 10 \mathrm{ppm}_{\mathrm{v}}$ ). The GC/FPD results for the injection and extraction well samples are considered satisfactory because dilution could not occur (i.e., samples were drawn directly from sampling ports). These concentrations were also well above the instrument-detection limit, and the measurements were verified by calibration checks and duplicate analyses.

Gas samples collected in Tedlar ${ }^{\mathrm{TM}}$ bags were also brought back to Pacific Northwest National Laboratory and analyzed by GC/ECD, which has a much lower detection limit for $\mathrm{SF}_{6}$ than does GC/FPD. The results are presented in Table 6.4. Note that preinjection air samples collected on September 25 had concentrations of $0.012 \mathrm{ppb}_{\mathrm{v}}$ (background site) and $0.913 \mathrm{ppb}_{\mathrm{v}}(\mathrm{E}-3)$. Note also that measurements for site locations were $<1 \mathrm{ppb}_{\mathrm{v}} \mathrm{SF}_{6}$ during the injection stage, except for samples taken at S-2, S-3, and S-12 $\left(1.11,1.74\right.$, and $46 \mathrm{ppb}_{\mathrm{v}}$, respectively). The values associated with $\mathrm{S}-2$ and $\mathrm{S}-3$, while still very low, suggest a limited emission of $\mathrm{SF}_{6}$ was occurring from the vicinity of the cover. A value of $145 \mathrm{ppb}_{\mathrm{v}} \mathrm{SF}_{6}$ was also noted in a sample collected from the small hole in the cover situated near S-2. The value associated with $\mathrm{S}-12$ is attributed to release of gas from the exhaust hose. A value of $1,183 \mathrm{ppb}_{\mathrm{v}} \mathrm{SF}_{6}$ was measured by GC/ECD for a sample collected at S-13 (the end of the exhaust hose) during the purge stage of the test.

\footnotetext{
${ }^{1}$ Foster Wheeler Environmental Corporation. 1995. Wellfield engineering design study for the hydrogen sulfide in situ pilot test. Richland, Washington.
} 
Table 6.4. Sulfur Hexafluoride Measurements by Gas Chromatograph/Electron Capture Detector

\begin{tabular}{|c|c|c|c|}
\hline Sample Location & Date & Time & Concentration $\left(\mathrm{ppb}_{\mathrm{v}}\right)$ \\
\hline$E-3$ & September 25, 1997 & 9:00 a.m. & 0.913 \\
\hline$S-1$ & September 25, 1997 & 9:00 a.m. & 0.012 \\
\hline S-1 & September 26, 1997 & 10:59 a.m. & 0.040 \\
\hline S-2 & September 26, 1997 & 11:00 a.m. & 1.11 \\
\hline S-3 & September 26, 1997 & 11:02 a.m. & 1.74 \\
\hline$S-4$ & September 26,1997 & 11:04 a.m. & 0.139 \\
\hline S-7 & September 26, 1997 & 11:06 a.m. & 0.033 \\
\hline S-6 & September 26, 1997 & 11:07 a.m. & 0.559 \\
\hline S-5 & September 26,1997 & 11:08 a.m. & 0.331 \\
\hline S-14 & September 26, 1997 & 11:10 a.m. & 0.371 \\
\hline S-15 & September 26, 1997 & 11:13 a.m. & 0.055 \\
\hline S-17 & September 26,1997 & 11:14 a.m. & 0.137 \\
\hline S-8 & September 26, 1997 & 11:16 a.m. & 0.036 \\
\hline S-10 & September 26, 1997 & 11:18 a.m. & 0.075 \\
\hline S-9 & September 26, 1997 & 11:19 a.m. & 0.268 \\
\hline S-11 & September 26, 1997 & $11: 26$ a.m. & 0.152 \\
\hline S-12 & September 26, 1997 & 12:37 p.m. & 46 \\
\hline Hole in cover & September 26, 1997 & 12:58 p.m. & 145 \\
\hline S-16 & September 26,1997 & 12:58 p.m. & 1.11 \\
\hline$S-13$ & September 26, 1997 & 2:07 p.m. & 1,183 \\
\hline$E-1$ & September 26, 1997 & 2:10 p.m. & 9,305 \\
\hline $\mathrm{E}-1$ & September 26, 1997 & 2:35 p.m. & 5,615 \\
\hline
\end{tabular}

Gas samples were also drawn from location E-1 during the purge stage and analyzed by both GC/FPD and GC/ECD (see Tables 6.3 and 6.4). Samples from E-1 indicate that $\mathrm{SF}_{6}$ concentrations in the extraction well dropped from $237 \mathrm{ppm}_{\mathrm{v}}$ during the injection stage to $\sim 161 \mathrm{ppm}_{\mathrm{v}}$ after $1 \mathrm{~h}$ of purging and to $<10 \mathrm{ppm}_{\mathrm{v}}$ after several hours of purging. These results suggested that a purge stage of several days would be adequate to flush residual $\mathrm{H}_{2} \mathrm{~S}$ from the site after completion of the gas-treatment demonstration. 


\subsection{Summary}

The gas-treatment system was determined to be fully operational based on satisfactory performance during the 32-h field tracer test. It was recommended, however, that the distance between the bleed valve and gas-mixing point on the injection line be increased to minimize back diffusion of $\mathrm{H}_{2} \mathrm{~S}$ through the bleed valve.

Measurement of pressures and flow rates for the well-field network and soil-gas-monitoring points during the tracer test suggested that a maximum injection flow rate of 25 to $30 \mathrm{ft}^{3} / \mathrm{min}$ could be maintained and still result in adequate capture, as indicated by negative pressures in the capture zone at a radial distance of $15 \mathrm{ft}$ from IGRS-1.

Mass-balance calculations of recovery of injected $\mathrm{SF}_{6}$ were also performed using the gasconcentration and flow-rate data acquired during the injection stage of the tracer test. Calculated capture of injected $\mathrm{SF}_{6}$ by the extraction well-field network ranged from $\sim 85 \%$ to $108 \%$. Thus, emission or release of $\mathrm{SF}_{6}$ to the site environment during the test is judged to have been minor. However, $\mathrm{SF}_{6}$ measurements for samples collected in the vicinity of the cover indicated possible minor accumulation of tracer gas under the cover. This problem can be addressed in field-treatment operations, if deemed necessary, by installing an additional extraction line near the center of the cover. However, the levels observed were well below the National Institute for Occupational Safety and Health permissible exposure limit for $\mathrm{H}_{2} \mathrm{~S}\left(10 \mathrm{ppm}_{\mathrm{v}}\right)$.

Analysis of a set of site background gas samples by GC/ECD yielded $\mathrm{SF}_{6}$ concentrations of $<2 \mathrm{ppb}_{\mathrm{v}}$. Thus, fugitive emissions to the site atmosphere during the tracer test were minor and indicated that levels of $\mathrm{H}_{2} \mathrm{~S}$ should be much less than 10 ppm $_{\mathrm{v}}$ (i.e., the proposed low-alarm level) at the site perimeter during the gas-treatment test. 


\subsection{Gas-Treatment Injection Test}

The gas-treatment injection test was initiated in mid-April and ran for 76 days through June 1998 at SWMU 143. The objective of this test was to treat the $\mathrm{CrO}_{4}{ }^{2-}$-contaminated soil at the demonstration site by injecting diluted $\mathrm{H}_{2} \mathrm{~S}^{1}$. Monitoring of the test was accomplished by analyzing the extracted gas stream for residual $\mathrm{H}_{2} \mathrm{~S}$, thereby identifying the onset of breakthrough and completion of the treatment reaction. Final performance evaluation involved posttreatment soil analysis and comparison to pretreatment $\mathrm{Cr}(\mathrm{VI})$ levels (discussed in Sections 8.0 and 9.0).

Another important objective of the test was to verify that injection of diluted $\mathrm{H}_{2} \mathrm{~S}$ could be undertaken in a safe and environmentally acceptable manner without significant release of the gas to the site atmosphere. To accomplish this, an environmental monitoring system was operated throughout the test. A site health and safety plan $^{2}$ was developed to support this demonstration objective and to define emergency response actions.

\subsection{Test Description}

During the gas-treatment injection test, diluted $\mathrm{H}_{2} \mathrm{~S}$ was prepared by introducing $\mathrm{H}_{2} \mathrm{~S}$ from a cylinder through a rotameter into an air stream produced by the injection blower. This mixture was injected into the site soils via the central well at a concentration of $200 \mathrm{ppm}_{\mathrm{v}}$ (see Figure 1.1). The air stream was then removed via the extraction wells by vacuum and pumped back to the treatment system. As illustrated in Figure 2.1, a caustic scrubber was incorporated into the treatment system to remove residual $\mathrm{H}_{2} \mathrm{~S}$ in the extraction air stream before release of the air back to the site environment. A granular activated carbon canister was not used during the demonstration because organic volatile concentrations in the extraction air stream were below limits specified by the site air permit.

Before initiating the gas-injection test, a water-feed tank was added to the system in December 1997/ January 1998 to replenish water evaporated from the scrubber by the extraction air stream. In addition, a vent was installed in the gas cabinet to remove any $\mathrm{H}_{2} \mathrm{~S}$ released from the cylinder into the cabinet and direct it into the gas scrubber (see Figure 2.1). The latter modification was incorporated into the design as a safety consideration because potential releases from the cylinder to the site environment were considered to be the most important risk associated with the demonstration (i.e., the source consisted of a 60-lb cylinder of liquefied $\mathrm{H}_{2} \mathrm{~S}$ ). Line power was also extended to the site, replacing the generator utilized during the tracer test.

\footnotetext{
${ }^{1}$ Thornton, EC, TJ Gilmore, and KB Olsen. 1998. Treatability test plan for the in situ gas treatment demonstration. Pacific Northwest National Laboratory, Richland, Washington.

${ }^{2}$ Fullmer, M. 1998. Site health and safety plan, in situ chemical treatment of soils by gaseous reduction. Pacific Northwest National Laboratory, Richland, Washington.
} 
The overall configuration of the treatment system and well field was presented in Figure 2.3. Figure 4.1 showed the locations of the soil-gas points that were used to obtain additional pressure data and gas-concentration measurements during the treatment test. The gas-treatment system is equipped with instrumentation to measure flow rates, injection and extraction pressures, and temperature of the injection and extraction gas streams. ${ }^{1}$

Well-field flow rates and pressures were measured during the test using mechanical gauges and differential pressure-flow sensors. Generally, well instrumentation was situated near the wellhead, whereas gauges associated with monitoring soil-point pressures were positioned on a panel on a table (Figure 7.1).

Electrochemical sensors were utilized to measure $\mathrm{H}_{2} \mathrm{~S}$ concentrations in the injection and extraction gas streams and internal to the network via the soil points. Concentrations were measured by pumping gas samples from the well lines or soil points and passing across the face of the sensor. The injection gas concentration was also calculated, using the measured flow rate of the injected air and the $\mathrm{H}_{2} \mathrm{~S}$ flow rate from the gas cylinder, and used as a check against the measured concentration.

\subsection{Environmental Monitoring and Alarm System}

Electrochemical sensors were utilized both for monitoring $\mathrm{H}_{2} \mathrm{~S}$ concentrations in the site environment and for personnel monitoring. ${ }^{2}$ The environmental or site monitors were positioned at four locations around the test site (M-1 through M-4; see Figure 7.1) and were interfaced to a data logger that established two alarm levels. The lower alarm was set at $10 \mathrm{ppm}_{\mathrm{v}}$ and a higher alarm set at $50 \mathrm{ppm}_{\mathrm{v}} \mathrm{H}_{2} \mathrm{~S}$. The lower alarm activated a yellow-flashing light and audible alarm; the higher alarm activated a red-flashing light. In addition, pagers were activated under alarm conditions to alert project staff, and a telephone alarm was activated to alert HELSTF staff. Pagers were also utilized to alert project staff in the event of an interruption of power to the treatment system.

\subsection{Performance of Test}

The first part of the gas-treatment-injection test consisted of an air-injection stage, which began on April 14, 1998. During this stage, injection and extraction of site air were undertaken using the gas system and well-field network. The objectives were to verify satisfactory operational status of the gastreatment system and to stabilize flow through the network.

Injection and extraction of the treatment gas mixture into the site soil were undertaken in the second stage of the test, which began on April 18. During this stage, injection and extraction air streams and soil

\footnotetext{
${ }^{1}$ Duchsherer, M. 1996. In-situ $\mathrm{H}_{2} S$ vapor injection/extraction skid operation manual. Westinghouse Hanford Company, Richland, Washington.

${ }^{2}$ Fullmer, M. 1998. Site health and safety plan, in situ chemical treatment of soils by gaseous reduction. Pacific Northwest National Laboratory, Richland, Washington.
} 
Road

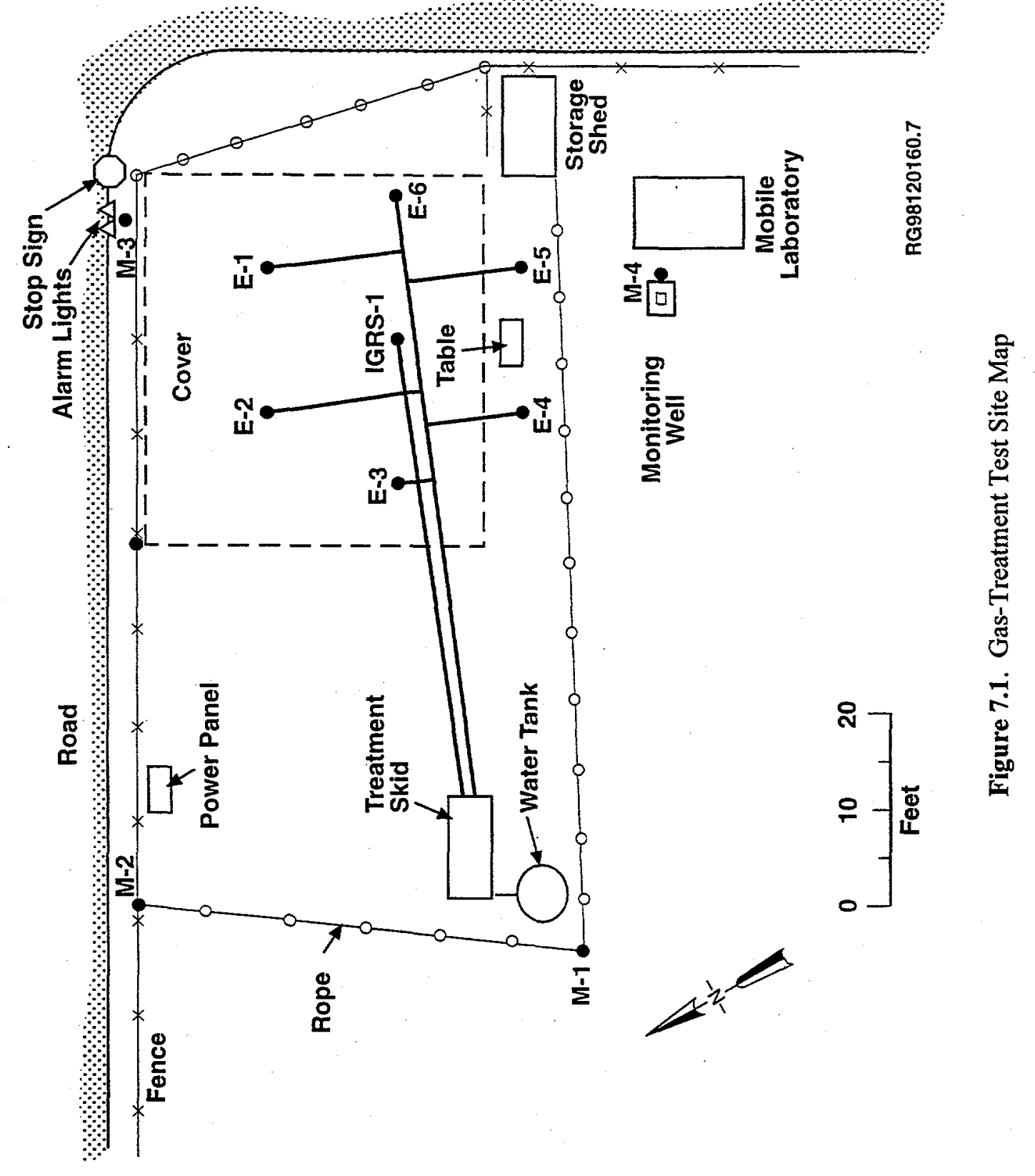


points were monitored for $\mathrm{H}_{2} \mathrm{~S}$ concentrations, with a primary objective of identifying breakthrough of $\mathrm{H}_{2} \mathrm{~S}$ at the extraction wells. Well-field flow rates and pressures and soil-point pressures were also monitored to determine gas-flow characteristics within the site. System operational characteristics were also monitored during this stage to evaluate long-term performance and to identify potential problems. The environmental monitoring and alarm system was fully operational throughout this stage of the test.

The final stage of the treatment test involved purging the site of residual $\mathrm{H}_{2} \mathrm{~S}$ by injecting and extracting air into the site. This stage was initiated on June 26 and completed on June 29, when the treatment system was turned off.

\subsection{Results}

The primary activities undertaken during the gas-treatment-injection test were the collection of treatment system performance information, well-field gas-flow and pressure data, well-field $\mathrm{H}_{2} \mathrm{~S}$ gasconcentration data, and performance information related to the operation of the environmental monitoring and alarm system. This information was recorded daily on log sheets (Figure 7.2) throughout the 76-day duration of the test. Portions of this information are presented in the tables in this section and are discussed below.

\subsubsection{Treatment System Performance}

The gas-treatment-injection system, including the newly installed water-feed system and gas-cabinet vent, performed in a generally acceptable manner throughout the test. Several problems were encountered, though of a relatively minor nature. Droplets of scrubber solution were observed to be blowing out of the stack early in the test, but this problem was remedied by directing the stack outlet into a waste barrel. The $\mathrm{H}_{2} \mathrm{~S}$ monitor on the scrubber stack also malfunctioned early in the test. This was determined to be the result of scrubber solution damaging the sensor element. A small water knockout was installed in the inlet line to the sensor to correct this problem.

A more difficult problem encountered was excessive heating of the extraction blower. This appeared to be related to development of a significant back pressure across the gas scrubber. This problem tended to become worse during the course of the test but abruptly improved late in the test. It is inferred that a blockage gradually developed in the scrubber system but was blown out as the back pressure increased. It is recommended that the scrubber gas lines be replaced with larger-diameter pipe to decrease back pressure problems in the future.

\subsubsection{Well-Field Pressures and Flow Rates}

All pressure/flow-rate data collected during the test can be found in Tables 7.1 and 7.2. Figure 7.3 presents the IGRS injection-pressure and flow-rate data and the sum of the extraction well flow rates during the injection test. The injection pressure for IGRS-1 was observed to decrease from 22 to 8 in. of water during the first several days of air injection. This decrease in injection pressure may be the result of the removal of soil moisture from around the injection well and the development of flow paths through 


\section{In-Situ Gaseous Reduction System Log Sheet}

Operator:

Start check time:

Windspeed and Direction:

Temperature: ${ }^{\circ} \mathrm{F}$

mph from

$F$

Date:

End check time:

Barometric Pressure:

Water Tank Level:

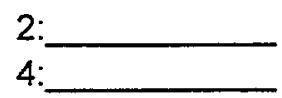

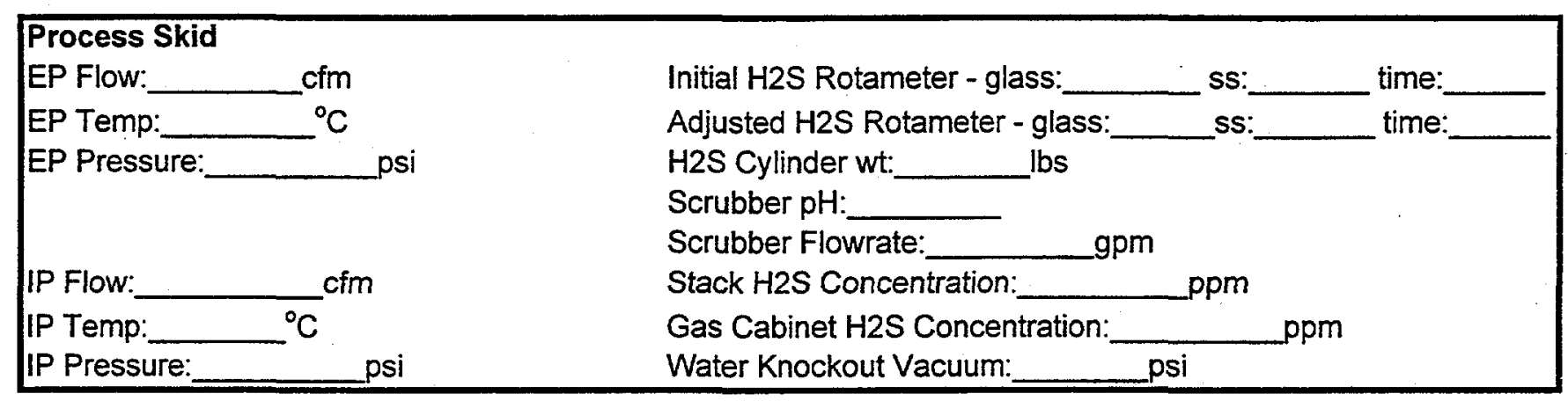

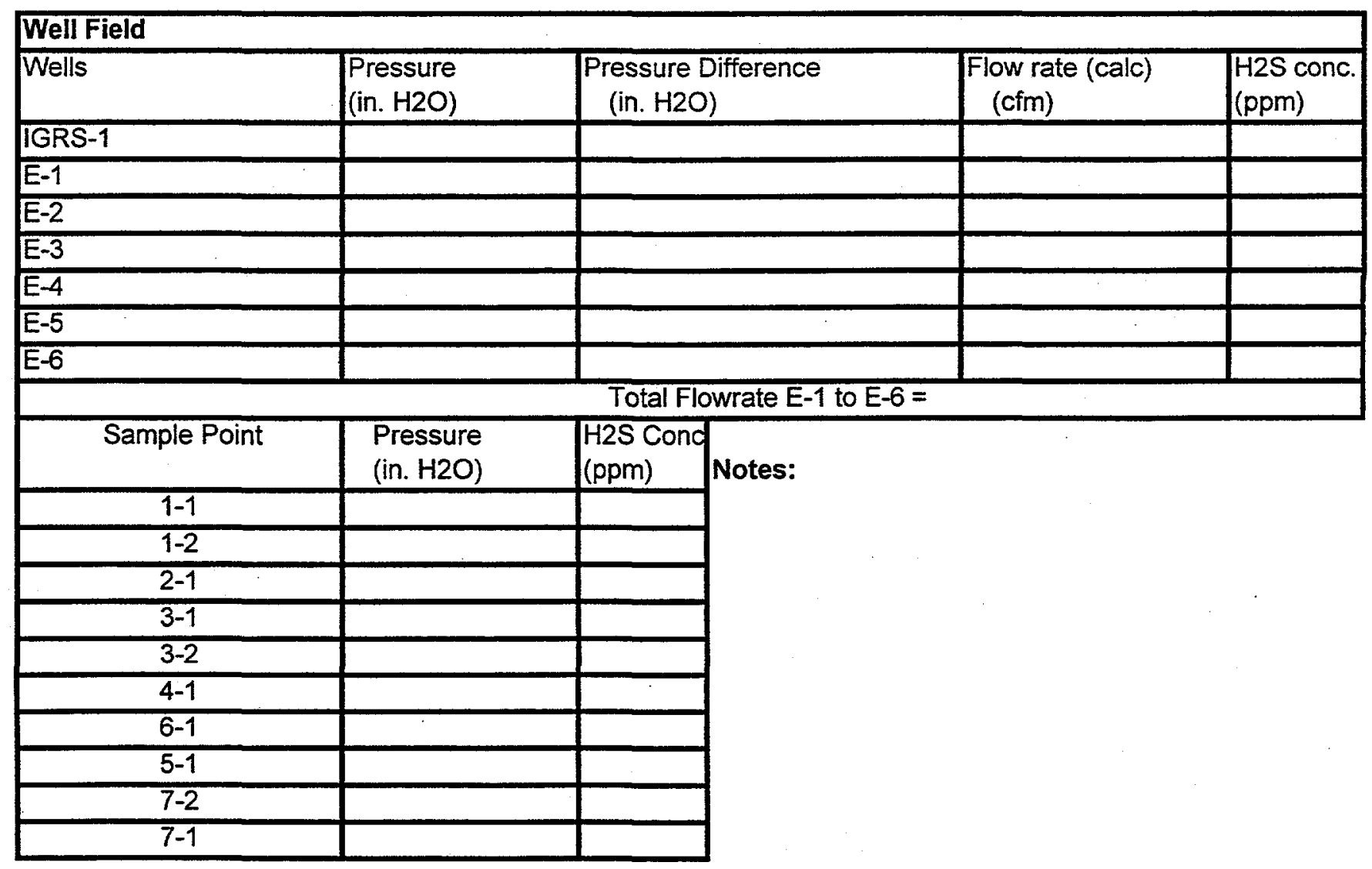

Figure 7.2. Daily Log Sheet 
Table 7.1. Gas-Treatment Test Well-Field Flow Rates and Pressures

\begin{tabular}{|c|c|c|c|c|c|c|c|c|c|c|c|c|c|c|c|c|}
\hline \multirow[b]{2}{*}{$\begin{array}{c}\text { Date } \\
(1998)\end{array}$} & \multirow[b]{2}{*}{ Time } & \multicolumn{8}{|c|}{ Well-Field Flow Rates $\left(\mathrm{ft}^{3} / \mathrm{min}\right)$} & \multicolumn{7}{|c|}{ Well-Field Pressures (in. of water) } \\
\hline & & $\begin{array}{c}\text { IGRS-1 } \\
\text { Flow }\end{array}$ & E-1 & E-2 & E-3 & $E-4$ & E-5 & E-6 & $\begin{array}{c}\text { Sum } E-1 \\
\text { to } E-6\end{array}$ & IGRS-1 & E-1 & E-2 & E-3 & E-4 & $E-5$ & E-6 \\
\hline $4 / 114$ & 1550 & 15 & 6 & $\bar{~} 4$ & $\overline{6}$ & 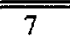 & 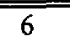 & $\overline{c 5.5}$ & 34.5 & +27 & -13 & $\begin{array}{l}-17 \\
\end{array}$ & -19 & -18 & 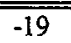 & -20 \\
\hline $4 / 15$ & 0840 & 25 & 6.5 & 4 & 4 & 9 & 7.5 & 6 & 37 & +23 & -11 & -16 & -18 & -17 & -18 & -18 \\
\hline $4 / 16$ & 0830 & OSR & 6 & 4 & 4 & 12 & 8 & 6 & 40 & +20 & $\mid-11$ & -15 & -17 & -16 & -16 & -17 \\
\hline $4 / 17$ & 0850 & 19 & 6 & 4.2 & 4 & 13 & 8.3 & 6 & 41.5 & +10 & -10 & -16 & -16 & -18 & -18 & -18 \\
\hline $4 / 18$ & 0815 & 20 & 6 & 4 & 4 & 13 & 9 & 6 & 42 & +9 & -12 & -16 & -17 & $\mid-17$ & -18 & -18 \\
\hline $4 / 18$ & 1605 & 20 & 6 & 4 & 4 & $\overline{13}$ & 8 & 6 & 41 & +8 & -10 & -16 & -16 & -16 & \begin{tabular}{|l|}
-18 \\
\end{tabular} & $\mid-18$ \\
\hline $4 / 19$ & 0125 & 20 & 6.5 & 4 & 4 & 13 & 9 & 6 & 42.5 & +8 & -11 & -16 & -17 & -16 & -16 & -18 \\
\hline $4 / 19$ & 0803 & 20 & 6 & 4 & 4 & 13 & 9 & 6 & 42 & +9 & -10 & -16 & -18 & $\mid-16$ & -16 & -18 \\
\hline $4 / 19$ & 1528 & 20 & 6 & 4 & 4 & 12 & 8 & 5.5 & 39.5 & +8 & -10 & -18 & -18 & -17 & -18 & -19 \\
\hline $4 / 20$ & 0942 & 20 & 6 & 4 & 4 & 12 & 8 & 6 & 40 & +8 & -11 & -15 & -16 & -15 & -16 & -17 \\
\hline $4 / 21$ & 0930 & 20 & 6 & 4 & 4 & 12 & 8 & 6 & 40 & +4 & -11 & -15 & -16 & -15 & -15 & -17 \\
\hline $4 / 22$ & 0958 & 27 & 6 & 4 & 4 & 12 & 8 & 6 & 40 & +10 & -11 & -15 & -16 & -15 & -16 & -17 \\
\hline $4 / 23$ & 0900 & 28 & 6 & 4 & 4 & 13 & 8 & 6 & 41 & +9 & -11 & -15 & -16 & -15 & -16 & -17 \\
\hline $4 / 24$ & 0930 & 28 & 5 & 4 & 4 & 13 & 8 & 5 & 39 & +9 & -11 & -15 & -16 & -15 & -16 & -17 \\
\hline $4 / 25$ & 1345 & 28 & 5 & 4 & 4 & 12 & 7 & 5 & 37 & +8 & -11 & -15 & -16 & -16 & -17 & -18 \\
\hline $4 / 26$ & 1225 & 29 & 6 & 4 & 4 & 13 & 9 & 6 & 42 & +8 & $\mid-11$ & -15 & -15 & -15.5 & -16 & -17 \\
\hline $4 / 27$ & 0935 & 30 & 6 & 4 & 4 & 13 & 4 & 6 & 37 & +8 & -10 & -14 & -15 & -13 & -15 & -16 \\
\hline $4 / 28$ & 1420 & 25 & 6 & 4 & 4 & 13 & 8 & 6 & 41 & +6 & -10 & -14 & -16 & -14 & -16 & -16 \\
\hline $4 / 29$ & 0910 & 27 & 5.4 & 4 & 4 & 12 & 8.5 & 6 & 39.9 & +6 & -10 & -14 & -16 & -14 & -14 & -16 \\
\hline $4 / 30$ & 1030 & 23 & 5 & 4 & 4 & 11 & 8 & 5 & 37 & +8 & -10 & -14 & -15 & $\mid-14$ & -16 & $\mid-16$ \\
\hline $5 / 1$ & 0810 & 27 & 6 & 2.5 & 2.5 & 12 & 8.5 & 5.5 & 36 & +6 & -10 & -14 & -16 & -14 & -16 & -17 \\
\hline $5 / 2$ & 0935 & 24 & 4.2 & 3 & 3 & 12 & 8.3 & 5.5 & 36 & +6 & -17 & -14 & -16 & -15 & $\begin{array}{c}-14 \\
\end{array}$ & -17 \\
\hline $5 / 3$ & 1240 & 23 & 5.5 & 3 & 3 & 12 & 7.8 & 5 & 36.3 & +6 & -11 & -14 & -16 & -15 & -16 & -17 \\
\hline $5 / 4$ & 0800 & 26 & 5 & 3 & 2.5 & 12 & 7.7 & 4.5 & 34.5 & +6 & -10 & -14 & -16 & -14 & -14 & -17 \\
\hline $5 / 5$ & 0850 & 26 & 4.9 & 2.5 & 2.5 & 12 & 7.5 & 4.2 & 33.6 & +6 & $\mid-10$ & -14 & -15 & $1-14$ & -15 & -16 \\
\hline $5 / 6$ & 0825 & 25 & 4.5 & 2 & 2 & 11 & 7.5 & 4 & 31.0 & +6 & -10 & -13 & -15 & $\mid-14$ & -14 & -16 \\
\hline $5 / 7$ & 1120 & 26 & 4.5 & 2.2 & 2.2 & 10 & 7 & 4.2 & 30.1 & +6 & -9 & -13 & -14 & -13 & -14 & -16 \\
\hline $5 / 8$ & 0815 & 26 & 4.4 & 2.3 & 2.3 & 10 & 7.2 & 4.4 & 30.6 & +6 & -8 & -12 & -13 & $\mid-13$ & -13 & -14 \\
\hline $5 / 9$ & 1040 & 26 & 4 & 2.3 & 2.3 & 8 & 6 & 4 & 26.6 & +6 & -6 & -10 & -11 & -11 & -11 & -12 \\
\hline $5 / 10$ & 1330 & 26 & 4.9 & 2.5 & 2.3 & 11 & 7.5 & 5 & 33.2 & +6 & -10 & -14 & -15 & -14 & -15 & -16 \\
\hline $5 / 10$ & 1440 & 26 & 5 & 2.5 & 2.5 & 12 & 8 & 5 & 35 & +6 & $\mid-11$ & -15 & -16 & -15 & -17 & -17 \\
\hline $5 / 11$ & 0903 & 26 & 5 & 2.5 & 2.3 & 12.5 & 8 & 4.6 & 34.9 & +6 & -12 & -16 & -17 & -15 & -16 & -18 \\
\hline $5 / 12$ & 1415 & 29 & 7 & 4 & 4 & 13 & 9 & 6 & 43 & +7 & -16 & -19 & -20 & -16 & -20 & -21 \\
\hline $5 / 13$ & 1025 & 29 & 7 & 4 & 4 & 14 & 11 & 7 & 47 & +7 & -16 & -20 & -22 & -17 & -21 & -22 \\
\hline $5 / 14$ & 0930 & 35 & 7 & 4 & 4 & 14 & 11 & 6 & 46 & +8 & -16 & -20 & -21 & -17 & -21 & -22 \\
\hline $5 / 15$ & 0900 & 38 & 8 & 4 & 4 & 14 & 13 & 7 & 50 & +9 & -21 & -24 & -25 & $\mid-19$ & -24 & -26 \\
\hline $5 / 16$ & 1348 & 37 & 7 & 3 & 3 & 14 & 13 & 6 & 46 & +9 & -20 & $\begin{array}{l}-23 \\
\end{array}$ & -24 & -19 & $\begin{array}{l}-24 \\
\end{array}$ & -25 \\
\hline $5 / 17$ & 1428 & 37 & 6 & 3 & 3 & 13 & 11 & 6 & 42 & +9 & -18 & -20 & -21 & -17 & -20 & -22 \\
\hline $5 / 18$ & 0915 & 37 & 7 & 3 & 3 & 14 & 13 & 6 & 46 & +9 & -20 & -24 & -25 & -19 & -23 & -26 \\
\hline $5 / 19$ & 1002 & 37 & 8 & 3 & 3 & 14 & 13 & 6 & 47 & +10 & -22 & -24 & -26 & -18 & -25 & -24 \\
\hline $5 / 20$ & 0802 & 37 & 6 & 3 & 3 & 13 & 13 & 6 & 44 & +9 & -18 & -22 & -23 & -16 & -22 & -24 \\
\hline $5 / 20$ & 1640 & 36 & 7.1 & 3 & 3 & 13 & 12 & 6 & 44.1 & +9 & -20 & -22 & -24 & -16 & -23 & -24 \\
\hline $5 / 21$ & 0957 & 36 & 6.5 & 3 & 2.8 & 12 & 11 & 5.5 & 40.8 & +9 & -16 & -20 & -21 & -16 & -21 & -22 \\
\hline $5 / 22$ & 0905 & 36 & 6.5 & 3 & 2.7 & 12 & 11 & 5.8 & 41.3 & +9 & -18 & -21 & -22 & -16 & -22 & -24 \\
\hline $5 / 23$ & 0839 & 38 & 6.5 & 3.4 & 3 & 12 & 11 & 5.7 & 41.6 & +8 & -18 & -21 & -22 & -16 & -22 & -24 \\
\hline $5 / 24$ & 0913 & 32 & 8 & 3.3 & 3 & 13 & 13 & 6.3 & 38.6 & +6 & -22 & -24 & -26 & -18 & -24 & $\mid-27$ \\
\hline
\end{tabular}


Table 7.1. (contd)

\begin{tabular}{|c|c|c|c|c|c|c|c|c|c|c|c|c|c|c|c|c|}
\hline \multirow[b]{2}{*}{$\begin{array}{c}\text { Date } \\
(1998)\end{array}$} & \multirow[b]{2}{*}{ Time } & \multicolumn{8}{|c|}{ Well-Field Flow Rates $\left(\mathrm{ft}^{3} / \mathrm{min}\right)$} & \multicolumn{7}{|c|}{ Well-Field Pressures (in. of water) } \\
\hline & & $\begin{array}{l}\text { IGRS-1 } \\
\text { Flow }\end{array}$ & E-1 & E-2 & E-3 & $\mathrm{E}-4$ & E-5 & $\mathrm{E}-6$ & $\begin{array}{c}\text { Sum E-1 } \\
\text { to E-6 }\end{array}$ & IGRS-1 & E-1 & E-2 & E-3 & E-4 & E-5 & E-6 \\
\hline $5 / 25$ & 0950 & $>40$ & 7.8 & 3.3 & 3.3 & $>14$ & 14 & $\overline{c 6.5}$ & $>41.1$ & +5 & -23 & -26 & -27 & $\overline{\mid-19}$ & -27 & -29 \\
\hline $5 / 26$ & 0915 & $>40$ & 8.2 & 3.5 & 3.5 & 13 & 13 & 6.5 & 47.7 & +4 & -23 & -26 & -27 & -24 & -27 & -29 \\
\hline $5 / 26$ & 1615 & 40 & 8 & 3.5 & 3.5 & 13 & 13 & 6.5 & 47.5 & +4 & -24 & -27 & -28 & -18 & -26 & -28 \\
\hline $5 / 27$ & 0930 & 41 & 8 & 3.5 & 3.5 & 14 & 14 & 6.5 & 49.5 & +4 & -24 & -27 & -28 & -18 & -27 & -30 \\
\hline $5 / 28$ & 0830 & 42 & 8.5 & 3.5 & 3.5 & 14 & 13 & 6.5 & 49 & +3.2 & -24 & -26 & -28 & -18 & -26 & -30 \\
\hline $5 / 28$ & 1600 & 42 & 8.5 & 3.5 & 3.5 & 13 & 12 & 6.5 & 47 & +3.4 & -26 & -29 & -30 & -18 & -26 & -31 \\
\hline $5 / 29$ & 0930 & 45 & 9.2 & 3.5 & 3.5 & 13 & 12 & 7.5 & 48.7 & +3.2 & -27 & -30 & -30 & -18 & -25 & -32 \\
\hline $5 / 30$ & 0910 & 45 & 12 & 4.2 & 4.2 & 13 & 13 & 8.5 & 54.9 & +3.1 & -37 & -40 & -40 & -19 & -27 & -42 \\
\hline $5 / 31$ & 0940 & 44 & 10 & 4 & 3.5 & 14 & 14 & 6 & 51.5 & +3.1 & -33 & -35 & -36 & $\mid-18$ & -26 & -38 \\
\hline $6 / 1$ & 0915 & 43 & 13 & 4.2 & 4 & 14 & 14 & 7.5 & 56.7 & +3.0 & -41 & -43 & -44 & -18 & -30 & -45 \\
\hline $6 / 2$ & 1045 & $\overline{43}$ & 8.7 & 4 & 3.5 & 14 & 14 & 5.8 & 50 & +3.0 & -30 & -32 & -33 & $\mid-18$ & -26 & -35 \\
\hline $6 / 3$ & 0750 & 42 & 7.5 & 3 & 2.5 & 13 & 14 & 5 & 45 & +3.1 & -28 & -30 & $\mid-31$ & -18.5 & -28 & -33 \\
\hline $6 / 4$ & 0630 & 42 & 10 & 4 & 2.8 & 14 & 14 & 7 & 51.8 & +2.85 & -38 & -40 & -40 & -20 & -34 & -42 \\
\hline $6 / 5$ & 0715 & 42 & 9.5 & 3.5 & 2.5 & 12 & 12 & 5.8 & 45.3 & +2.9 & -30.5 & -33 & -35 & -12.5 & -21.5 & -38.5 \\
\hline $6 / 6$ & 0800 & 43 & 8.7 & 4 & 2.8 & 12 & 12 & 6 & 45.5 & +3.0 & -30 & -32 & -33 & -14.5 & -20 & -35 \\
\hline $6 / 7$ & 0857 & 42 & 12 & 4 & 2.8 & 13 & 13 & 7 & 51.8 & +3.0 & -39 & -40 & -41 & -17 & -26 & -42 \\
\hline $6 / 8$ & 0750 & 43 & 8.5 & 3 & 1.8 & 11 & 11 & 5 & 40.3 & +3.0 & -30 & -30 & -32 & -14 & -20 & -34 \\
\hline $6 / 9$ & 0823 & 45 & \begin{tabular}{|l|}
11 \\
\end{tabular} & 4 & 2.2 & 13 & 14 & 6.5 & 50.7 & +2.8 & -40 & -40 & 41 & -17 & -28 & -44 \\
\hline $6 / 10$ & 0825 & 56 & 11 & 4.2 & 2.5 & 13.5 & 14 & 6.5 & 51.7 & +4.4 & -40 & -42 & -43 & -18 & $\begin{array}{l}-28 \\
\end{array}$ & -45 \\
\hline $6 / 11$ & 1120 & 56 & 12.5 & 5 & 2.8 & 13 & 12.5 & 6 & 51.8 & +4.5 & -43 & -45 & -46 & -20 & -31 & -48 \\
\hline $6 / 12$ & 1010 & 56 & 12 & 4.4 & 2.9 & 13 & 12.5 & 4.8 & 49.6 & +4.55 & -39 & -40 & -41 & -19 & -28 & -44 \\
\hline $6 / 13$ & 0830 & 56 & 9.5 & 3.5 & 2.3 & 12 & 12 & 4.5 & 43.8 & +4.6 & -34 & -34.5 & -36 & -18 & -25 & -39 \\
\hline $6 / 14$ & 0750 & 56 & 8.4 & 3.3 & 1.9 & 11 & 10 & 4.2 & 38.8 & +4.5 & -28 & -29 & -30 & -15 & -22 & -34 \\
\hline $6 / 15$ & 0805 & 56 & 9 & 3.5 & 2.4 & 11.5 & 11 & 5 & 42.4 & +4.45 & -30 & -32.5 & -33 & -15 & $\begin{array}{l}-24 \\
\end{array}$ & -36 \\
\hline $6 / 16$ & 0630 & 56 & 10.5 & 4 & 2.2 & 13 & 13 & 6.2 & 48.9 & +4.45 & -37 & -39 & -39 & -19 & $\begin{array}{l}-30 \\
\end{array}$ & -41 \\
\hline $6 / 17$ & 0815 & 56 & 8 & 2.9 & 1.9 & 11 & 10.5 & 4.5 & 38.8 & +4.45 & -27 & -29 & -30 & -15 & -23 & -32 \\
\hline $6 / 18$ & 0805 & 56 & 10 & 4 & 2.2 & 12.5 & 12.5 & 6 & 477.2 & +4.45 & -34 & -35 & -36 & -18 & -28 & -39 \\
\hline $6 / 19$ & 1720 & 55 & 13 & 4.2 & 4 & 13 & 13 & 8.5 & 55.7 & +4.45 & -49 & -50 & -50 & -20 & -31 & -52 \\
\hline $6 / 20$ & 0803 & 56 & 13 & 4.6 & 4 & 13 & 13 & 7.5 & \begin{tabular}{ll|}
55.1 \\
\end{tabular} & +4.4 & -50 & -50 & -51 & -19 & -29 & -54 \\
\hline $6 / 21$ & 0800 & 56 & 13 & 4.4 & 4 & 13 & 13 & 6.1 & 53.5 & +4.40 & -50 & -50 & -52 & -18 & -28 & -55 \\
\hline $6 / 22$ & 0818 & 56 & 13 & 4.5 & 4 & 13 & 13 & 6 & 53.5 & +4.4 & -50 & -51 & -52 & $\mid-19$ & -28 & -55 \\
\hline $6 / 23$ & 1033 & 56 & 13 & 4.5 & 4.1 & 13 & 13 & 6.1 & 53.7 & +4.45 & -49 & -51 & -53 & -18 & -28 & -55 \\
\hline $6 / 24$ & 0810 & 56 & 13 & 4.5 & 4 & 13 & 13 & 6 & 53.5 & +4.4 & -48 & -50 & -52 & -18 & -28 & -55 \\
\hline $6 / 25$ & 0815 & 56 & 13 & 4.3 & 3.9 & 13 & 13 & 6.1 & 53.3 & -4.5 & -48 & -50 & -52 & -18 & -28 & -55 \\
\hline $6 / 26$ & 0723 & 56 & 13 & 4.6 & 3.9 & 13 & 13 & 6 & 53.5 & +4.45 & -49 & -51 & -52 & -18 & -29 & -55 \\
\hline $6 / 27$ & 1033 & 56 & 13 & 4.2 & 3.9 & 13 & 13 & 6 & 53.1 & +4.45 & -48 & -50 & -52 & -18 & -29 & -54 \\
\hline $6 / 28$ & 0910 & 56 & 12.5 & 4.3 & 3.9 & 13 & 13 & 6.1 & 52.8 & +4.4 & -47 & -50 & -51 & -18 & -29 & -54 \\
\hline $6 / 29$ & 0835 & 56 & 12.5 & 4.2 & 3.9 & 13 & 13 & 6.1 & 52.7 & +4.6 & -47 & -50 & -52 & -19 & -29 & -55 \\
\hline
\end{tabular}


Table 7.2. Soil-Sampling Point Pressures

\begin{tabular}{|c|c|c|c|c|c|c|c|c|c|c|c|}
\hline \multirow{2}{*}{$\begin{array}{c}\text { Date } \\
(1998)\end{array}$} & \multirow[b]{2}{*}{ Time } & \multicolumn{10}{|c|}{ Soil-Gas-Sampling Points - Pressure Readings (in. of water) } \\
\hline & & $1-1$ & $1-2$ & $2-1$ & $3-1$ & $3-2$ & 4-1 & $6-1$ & $5-1$ & $7-2$ & $7-1$ \\
\hline $4 / 14$ & 1550 & OSL & -0.04 & OSL & OSL & 0.02 & 0.12 & OSL & OSL & OSR & OSR \\
\hline $4 / 15$ & 0840 & OSL & 0.03 & OSL & OSL & OSL & 0.05 & OSL & OSL & OSR & -0.96 \\
\hline $4 / 16$ & 0830 & -0.035 & -0.037 & OSL & OSL & OSL & -0.02 & OSL & OSL & OSR & -0.85 \\
\hline $4 / 17$ & 0850 & -0.04 & -0.075 & OSL & 0.0 & -0.03 & -0.09 & OSL & OSL & OSR & OSR \\
\hline $4 / 18$ & 0815 & -0.025 & -0.062 & OSL & OSL & -0.02 & -0.08 & OSL & OSL & OSR & -1.0 \\
\hline $4 / 18$ & 1605 & -0.06 & -0.11 & OSL & -0.03 & -0.05 & -0.10 & OSL & OSL & OSR & OSR \\
\hline $4 / 19$ & 0125 & -0.02 & -0.06 & OSL & OSL & -0.02 & -0.08 & OSL & OSL & OSR & OSR \\
\hline $4 / 19$ & 0803 & -0.03 & -0.07 & OSL & OSL & -0.02 & -0.08 & OSL & OSL & OSR & -0.99 \\
\hline $4 / 19$ & 1528 & -0.05 & -0.095 & OSL & -0.005 & -.03 & -.09 & OSL & OSL & $\overline{\text { OSR }}$ & OSR \\
\hline $4 / 20$ & 0942 & -0.08 & -0.11 & OSL & -0.01 & -0.05 & -0.10 & OSL & OSL & OSR & OSR \\
\hline $4 / 21$ & 0930 & -0.03 & -0.07 & OSL & OSL & -0.01 & -0.06 & OSL & $\mathrm{OSL}$ & OSR & -0.96 \\
\hline $4 / 22$ & 0958 & -0.03 & -0.06 & OSR & OSL & $\overline{\mathrm{OSL}}$ & -0.03 & OSL & OSL & OSR & -0.88 \\
\hline $4 / 23$ & 0900 & -0.035 & -0.065 & OSR & OSL & OSL & -0.02 & OSL & OSL & OSR & -0.84 \\
\hline $4 / 24$ & 0930 & -0.03 & -0.06 & OSR & OSL & OSL & -0.02 & OSL & OSL & OSR & -0.88 \\
\hline $4 / 25$ & 1345 & -0.02 & -0.05 & OSR & OSL & OSL & OSL & OSL & OSL & OSR & -0.83 \\
\hline $4 / 26$ & 1225 & -0.005 & -0.04 & OSR & OSL & OSL & OSL & OSL & OSL & OSR & -0.82 \\
\hline $4 / 27$ & 0935 & -0.02 & -0.05 & OSR & OSL & OSL & OSL & OSL & $\mathrm{OSL}$ & OSR & -0.74 \\
\hline $4 / 28$ & 1420 & -0.05 & -0.07 & $\mathrm{OSL}$ & OSL & OSL & -0.03 & OSL & OSL & $\overline{\text { OSR }}$ & -0.86 \\
\hline $4 / 29$ & 0910 & -0.03 & -0.06 & OSL & OSL & OSL & -0.04 & OSL & OSL & OSR & -0.80 \\
\hline $4 / 30$ & 1030 & -0.05 & -0.07 & 0.19 & 0.06 & OSL & -0.035 & 0.07 & 0.07 & OSR & -0.82 \\
\hline $5 / 1$ & 0810 & -0.035 & -0.06 & 0.20 & 0.06 & OSL & -0.04 & 0.075 & 0.075 & OSR & -0.86 \\
\hline $5 / 2$ & 0935 & -0.04 & -0.07 & 0.20 & 0.06 & 0.00 & -0.05 & 0.08 & 0.075 & OSR & -0.86 \\
\hline $5 / 3$ & 1240 & -0.045 & -0.075 & 0.215 & 0.075 & OSL & -0.04 & 0.085 & 0.09 & OSR & -0.86 \\
\hline $5 / 4$ & 0800 & -0.03 & -0.07 & 0.22 & 0.08 & OSL & -0.06 & 0.095 & 0.09 & OSR & -0.85 \\
\hline $5 / 5$ & 0850 & -0.04 & -0.06 & 0.215 & 0.07 & OSL & -0.03 & 0.075 & 0.08 & OSR & -0.80 \\
\hline $5 / 6$ & 0825 & -0.01 & -0.04 & 0.23 & 0.09 & OSL & -0.01 & 0.10 & 0.10 & OSR & -0.77 \\
\hline $5 / 7$ & 1120 & -0.025 & -0.035 & 0.24 & 0.08 & OSL & -0.01 & 0.097 & 0.095 & OSR & -0.70 \\
\hline $5 / 8$ & 0815 & -0.005 & -0.02 & OSR & 0.115 & OSL & OSL & 0.12 & 0.13 & OSR & -0.64 \\
\hline $5 / 9$ & 1040 & -0.02 & 0.026 & 0.245 & 0.096 & OSL & OSL & 0.111 & 0.119 & OSR & -0.47 \\
\hline $5 / 10$ & 1330 & -0.01 & -0.01 & OSR & 0.10 & OSL & -0.01 & 0.11 & 0.12 & OSR & -0.75 \\
\hline $5 / 10$ & 1440 & -0.03 & -0.055 & 0.23 & 0.086 & OSL & -0.03 & 0.10 & 0.095 & OSR & -0.84 \\
\hline $5 / 11$ & 0903 & -0.03 & -0.05 & 0.22 & 0.08 & OSL & -0.03 & 0.09 & 0.09 & OSR & -0.87 \\
\hline $5 / 12$ & 1415 & -0.03 & -0.06 & OSR & 0.10 & OSL & -0.04 & 0.12 & 0.13 & OSR & OSR \\
\hline $5 / 13$ & 1025 & -0.03 & -0.07 & OSR & 0.08 & OSL & -0.06 & 0.11 & 0.10 & OSR & OSR \\
\hline $5 / 14$ & 0930 & -0.03 & -0.06 & OSR & 0.11 & OSL & -0.02 & 0.13 & 0.13 & OSR & OSR \\
\hline $5 / 15$ & 0900 & -0.03 & -0.07 & OSR & 0.11 & OSL & -0.03 & 0.14 & 0.14 & OSR & -1.02 \\
\hline $5 / 16$ & 1348 & -0.03 & -0.06 & OSR & 0.14 & OSL & -0.02 & 0.16 & 0.16 & OSR & -1.0 \\
\hline $5 / 17$ & 1428 & -0.04 & -0.07 & OSR & 0.14 & OSL & -0.01 & 0.16 & 0.16 & OSR & -0.86 \\
\hline $5 / 18$ & 0915 & -0.04 & -0.08 & OSR & 0.11 & OSL & -0.02 & 0.14 & 0.14 & OSR & -1.02 \\
\hline $5 / 19$ & 1002 & -0.04 & -0.075 & OSR & 0.115 & OSL & -0.03 & 0.145 & 0.135 & OSR & OSR \\
\hline $5 / 20$ & 0802 & -0.015 & -0.045 & OSR & 0.135 & OSL & OSL & 0.16 & 0.165 & OSR & -0.86 \\
\hline $5 / 20$ & 1640 & -0.024 & -0.045 & OSR & 0.14 & OSL & 0.05 & 0.155 & 0.16 & OSR & -0.94 \\
\hline $5 / 21$ & 0957 & -0.023 & -0.045 & OSR & 0.145 & OSL & OSL & 0.16 & 0.17 & OSR & -0.83 \\
\hline
\end{tabular}


Table 7.2. (contd)

\begin{tabular}{|c|c|c|c|c|c|c|c|c|c|c|c|}
\hline \multirow{2}{*}{$\begin{array}{c}\text { Date } \\
(1998)\end{array}$} & \multirow[b]{2}{*}{ Time } & \multicolumn{10}{|c|}{ Soil-Gas-Sampling Points - Pressure Readings (in. of water) } \\
\hline & & $1-1$ & $1-2$ & $2-1$ & $3-1$ & $3-2$ & $4-1$ & $6-1$ & $5-1$ & $7-2$ & $7-1$ \\
\hline $5 / 22$ & 0905 & -0.01 & -0.04 & OSR & 0.14 & OSL & $\overline{\mathrm{OSL}}$ & 0.16 & 0.16 & OSR & -0.87 \\
\hline $5 / 23$ & 0839 & -0.03 & -0.05 & OSR & 0.16 & OSL & OSL & 0.18 & 0.18 & OSR & -0.84 \\
\hline $5 / 24$ & 0913 & $\begin{array}{l}-0.03 \\
\end{array}$ & -0.07 & OSR & 0.16 & OSL & OSL & 0.19 & 0.20 & OSR & -0.98 \\
\hline $5 / 25$ & 0950 & -0.05 & -0.09 & $\overline{O S R}$ & 0.15 & OSL & OSL & 0.19 & 0.20 & OSR & -1.00 \\
\hline $5 / 26$ & 0915 & -0.04 & -0.08 & OSR & 0.19 & OSL & OSL & 0.21 & 0.22 & OSR & -1.00 \\
\hline $5 / 26$ & 1615 & -0.03 & -0.06 & OSR & 0.17 & OSL & OSL & 0.20 & OSR & OSR & OSR \\
\hline $5 / 27$ & 0930 & -0.03 & -0.06 & OSR & 0.18 & $\overline{\text { OSL }}$ & OSL & 0.20 & 0.20 & OSR & -1.00 \\
\hline $5 / 28$ & 0830 & -0.04 & -0.07 & 0.46 & 0.16 & 0.12 & 0.07 & 0.20 & 0.21 & -3.50 & -0.92 \\
\hline $5 / 28$ & 1600 & -0.04 & -0.07 & 0.47 & 0.19 & 0.14 & 0.06 & 0.21 & 0.21 & -3.6 & -0.94 \\
\hline $5 / 29$ & 0930 & -0.035 & -0.07 & 0.47 & 0.17 & 0.11 & 0.05 & 0.20 & 0.20 & -3.75 & -0.98 \\
\hline $5 / 30$ & 0910 & -0.04 & -0.07 & 0.44 & 0.15 & 0.08 & OSL & 0.18 & 0.17 & -4.50 & OSR \\
\hline $5 / 31$ & 0940 & -0.04 & -0.06 & 0.46 & 0.18 & 0.13 & 0.07 & 0.20 & 0.20 & -3.40 & -0.88 \\
\hline $6 / 1$ & 0915 & -0.04 & -0.09 & 0.44 & 0.15 & 0.09 & -0.12 & 0.18 & 0.17 & -4.20 & OSR \\
\hline $6 / 2$ & 1045 & -0.04 & -0.07 & 0.47 & 0.19 & 0.15 & -0.05 & 0.21 & 0.21 & -3.10 & -0.76 \\
\hline $6 / 3$ & 0750 & -0.03 & -0.06 & -0.48 & 0.19 & 0.15 & -0.03 & 0.21 & 0.22 & -3.00 & -0.71 \\
\hline $6 / 4$ & 0630 & OSL & -0.03 & 0.48 & 0.17 & 0.12 & -0.08 & 0.20 & 0.13 & -3.60 & -0.92 \\
\hline $6 / 5$ & 0715 & -0.02 & -0.03 & 0.50 & 0.19 & 0.16 & -0.04 & 0.23 & 0.25 & -2.60 & -0.58 \\
\hline $6 / 6$ & 0800 & -0.01 & -0.03 & 0.51 & 0.21 & 0.17 & -0.01 & 0.23 & 0.23 & -2.80 & -0.06 \\
\hline $6 / 7$ & 0857 & -0.02 & -0.05 & 0.48 & 0.19 & 0.14 & -0.06 & 0.21 & 0.20 & -3.40 & -0.87 \\
\hline $6 / 8$ & $0750^{\circ}$ & -0.01 & -0.03 & 0.52 & 0.21 & 0.17 & -0.01 & 0.23 & 0.25 & -2.70 & -0.60 \\
\hline $6 / 9$ & 0823 & 0.00 & -0.06 & 0.46 & 0.17 & 0.14 & -0.06 & 0.19 & 0.18 & -3.30 & 0.81 \\
\hline $6 / 10$ & 0825 & -0.01 & -0.03 & 0.75 & $\overline{\text { OSR }}$ & 0.25 & 0.10 & OSR & $\overline{\text { OSR }}$ & -3.45 & -0.63 \\
\hline $6 / 11$ & 1120 & -0.12 & -0.14 & 0.71 & 0.29 & 0.28 & 0.05 & 0.33 & 0.30 & -2.95 & -0.55 \\
\hline $6 / 12$ & 1010 & -0.09 & -0.10 & 0.74 & OSR & 0.26 & 0.09 & OSR & OSR & -2.55 & -0.41 \\
\hline $6 / 13$ & 0830 & -0.06 & -0.05 & 0.76 & OSR & 0.29 & 0.16 & OSR & OSR & -2.20 & -0.27 \\
\hline $6 / 14$ & 0750 & -0.50 & -0.04 & 0.79 & OSR & 0.30 & 0.20 & OSR & OSR & -1.95 & -0.17 \\
\hline $6 / 15$ & 0805 & -0.04 & -0.04 & 0.08 & OSR & 0.30 & 0.20 & OSR & OSR & -2.55 & -0.37 \\
\hline $6 / 16$ & 0630 & -0.02 & -0.03 & 0.77 & OSR & 0.27 & 0.14 & OSR & OSR & -3.30 & -0.63 \\
\hline $6 / 17$ & 0815 & OSL & OSL & 0.83 & OSR & 0.39 & 0.26 & OSR & OSR & -2.10 & -0.20 \\
\hline $6 / 18$ & 0805 & -0.03 & -0.03 & 0.77 & OSR & 0.29 & 0.16 & OSR & OSR & -3.00 & -0.52 \\
\hline $6 / 19$ & 1720 & -0.03 & -0.08 & 0.71 & $\overline{\text { OSR }}$ & 0.25 & 0.05 & OSR & OSR & -4.20 & -1.00 \\
\hline $6 / 20$ & 0803 & -0.03 & -0.04 & 0.72 & 0.27 & 0.26 & 0.00 & 0.33 & 0.30 & -3.45 & -0.71 \\
\hline $6 / 21$ & 0800 & -0.03 & -0.04 & 0.71 & OSR & 0.23 & -0.10 & OSR & $\overline{\mathrm{OSR}}$ & -2.75 & -0.49 \\
\hline $6 / 22$ & 0818 & -0.03 & -0.05 & 0.70 & OSR & 0.26 & -0.11 & OSR & OSR & -2.65 & -0.45 \\
\hline $6 / 23$ & 1033 & -0.03 & -0.05 & 0.71 & OSR & 0.25 & -0.10 & OSR & $\overline{\text { OSR }}$ & -2.70 & -0.46 \\
\hline $6 / 24$ & 0810 & -0.02 & -0.04 & 0.72 & OSR & 0.24 & -0.10 & OSR & OSR & -2.71 & -0.45 \\
\hline $6 / 25$ & 0815 & -0.03 & -0.05 & 0.70 & OSR & 0.23 & -0.10 & OSR & OSR & -2.73 & -0.44 \\
\hline $6 / 26$ & 0723 & -0.02 & -0.04 & 0.71 & $\overline{\text { OSR }}$ & 0.24 & -0.10 & OSR & OSR & -2.73 & -0.46 \\
\hline $6 / 27$ & 1033 & -0.04 & -0.05 & 0.68 & $\overline{\text { OSR }}$ & 0.23 & 0.11 & OSR & OSR & -2.65 & -0.46 \\
\hline $6 / 28$ & 0910 & -0.03 & -0.05 & 0.69 & OSR & 0.23 & -0.09 & OSR & OSR & -2.67 & -0.45 \\
\hline $6 / 29$ & 0835 & -0.03 & -0.05 & 0.70 & OSR & 0.24 & -0.10 & OSR & OSR & -2.72 & -0.46 \\
\hline
\end{tabular}




\section{Pressure Data}

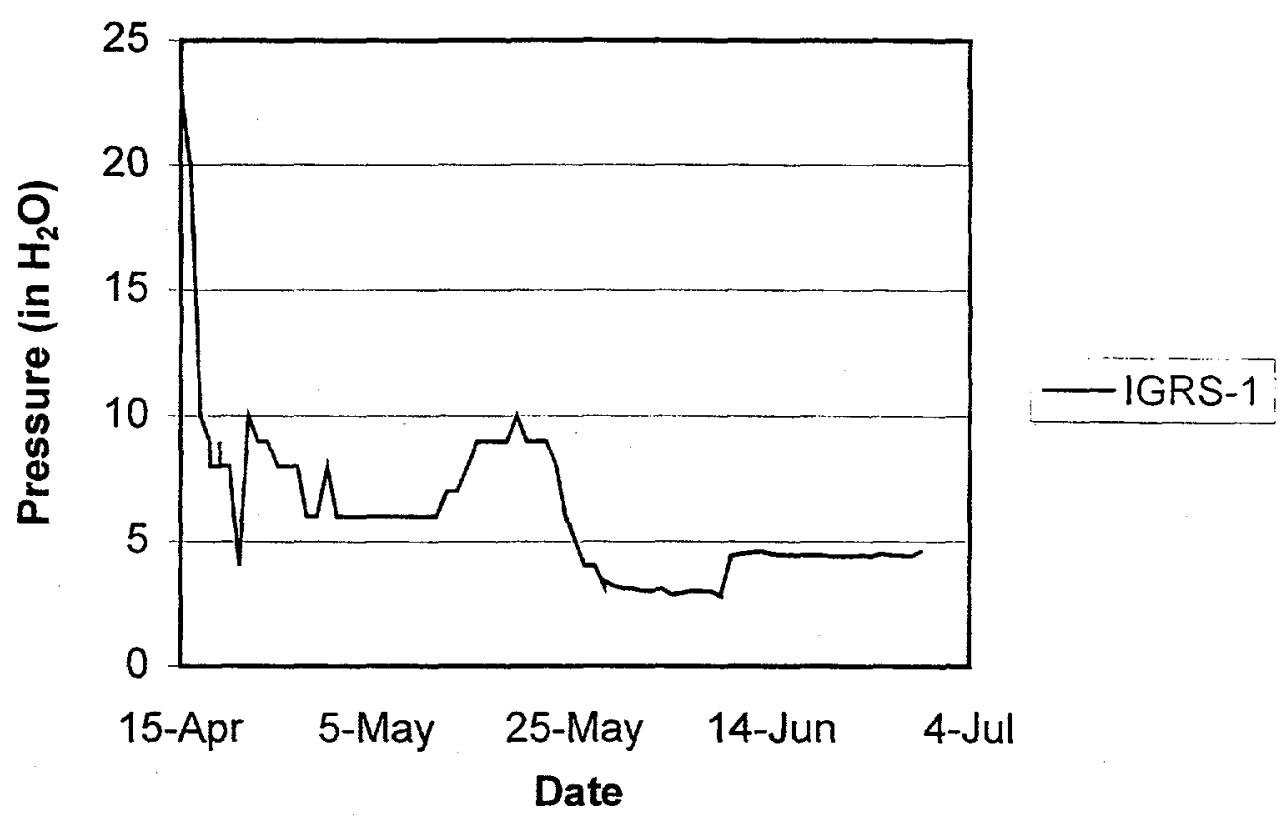

Flow Data

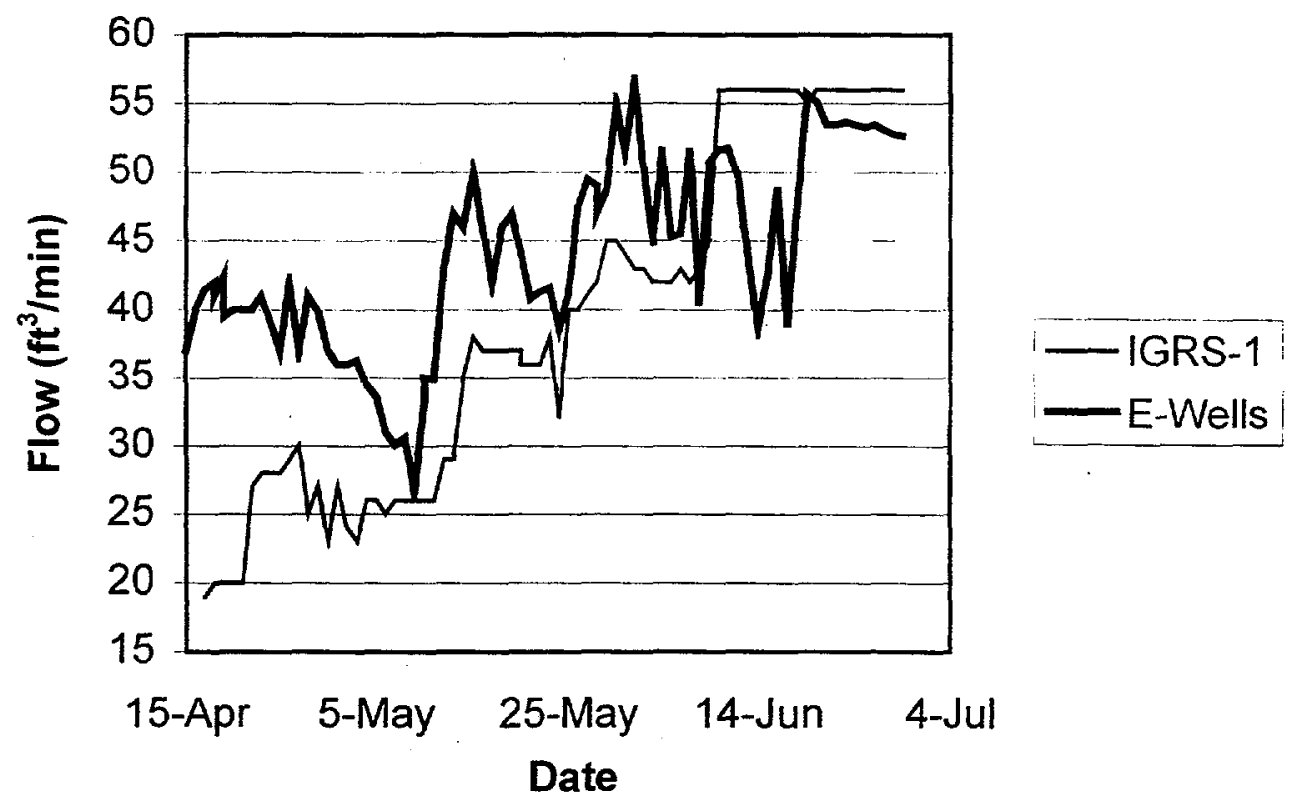

Figure 7.3. Injection Pressure and Flow-Rate Data and Sum of Extraction Well Flow Rates 
the test site. Injection pressures throughout the remainder of the test range from 3 to 10 in. of water. Injection and extraction flow rates were manually controlled throughout the test at the gas-treatment system. During the early phases of the injection test, flows were set at $\sim 20$ to 30 and 37 to $42 \mathrm{ft}^{3} / \mathrm{min}$, respectively, for injection and extraction flow rates. The ratios between extraction and injection flow rates were set initially at $\sim 2$ to 1 to obtain a high-capture efficiency for unreacted $\mathrm{H}_{2} \mathrm{~S}$. As the test proceeded, both injection and extraction flow rates were increased to a 1 to 1 relationship. During this latter period of the test, injection flow rates ranged from 42 to $57 \mathrm{ft}^{3} / \mathrm{min}$ and extraction flow rates ranged from 40 to $56 \mathrm{ft}^{3} / \mathrm{min}$. During this same latter period of injection, when injection flow slightly exceeded the extraction flow rate, no $\mathrm{H}_{2} \mathrm{~S}$ was released to the atmosphere.

The flow rates for the extraction wells were found to vary significantly. In wells E-1, E-4 and E-5, flow rates ranged from 4 to $14 \mathrm{ft}^{3} / \mathrm{min}$ and were consistently higher than in wells E-2, E-3, and E-6. Toward the end of the test, when extraction flow rates were increased, the flow rate from well E-4 and $\mathrm{E}-5$ had to be throttled at the wellhead to $<14 \mathrm{ft}^{3} / \mathrm{min}$. Flow rates in wells $\mathrm{E}-2$ and $\mathrm{E}-3$ ranged from 2.5 to $4.2 \mathrm{ft}^{3} / \mathrm{min}$ and were consistently lower than the other four extraction wells. The flow rate in well E-6 ranged from 4 to $8.5 \mathrm{ft}^{3} / \mathrm{min}$, which was in between the high and low wells. The differences in flow rates between the wells may be the result of the covering material and/or the permeability of the soil around the extraction well. Wells E-4 and E-5 were located in an area covered by asphalt (asphalt is known to have cracks, which may allow the influx of ambient air into the extraction well); whereas E-1, E-2, E-3, and E-6 were within the area covered by an impermeable liner.

Figure 7.4 presents the differential pressures measured at the extraction wells during the test. The differential pressures at all the wells were shown to decrease through the injection test. This decrease was caused by manually increasing the extraction flow on the gas-treatment system. However, the magnitude of change at the extraction wells was different. Wells E-1, E-2, E-3, and E-6 started at - 15 in. of water and decreased to -50 in. of water. The differential pressures at E-4 and E-5 followed a similar response but only ranged from -15 to $-30 \mathrm{in}$. of water during the test. It is interesting to note the inverse relationship between flow rates and differential pressure at the extraction wells. Wells with the highest flows have the lowest differential pressure; wells with the lowest flows have the highest differential pressure. Again, these differences may be attributed to the covering material and/or the permeability of the soil around the extraction wells.

Figure 7.5 presents the differential pressures at the soil-gas-sampling points located across the site during the test. Soil-gas points with two plots represent data from two levels in the same borehole. The "- 1 " represents data from the top sampling point, which is located in the less-consolidated (i.e., higher permeability) sediment horizon of the test site. The " 2 " represents data from the lower sampling point, which is located in the more-consolidated, less-permeable sediments of the test site. Initially, the differential pressures at the soil-gas-sampling points were compared with differential pressures at the extraction wells located closed to the soil-gas points. However, no pressure correlation was found. Thus, a more general comparison was made. If the differential pressure at the soil-gas-sampling point was negative, the soil-gas-sampling point was under the influence of the extraction well, which was operating at negative pressure. If the differential pressure at the soil-gas-sampling point was positive, the soil-gassampling point was under the influence of the injection well, which was operating at a positive pressure. Several points were found to be under the influence of both injection and extraction wells at different 

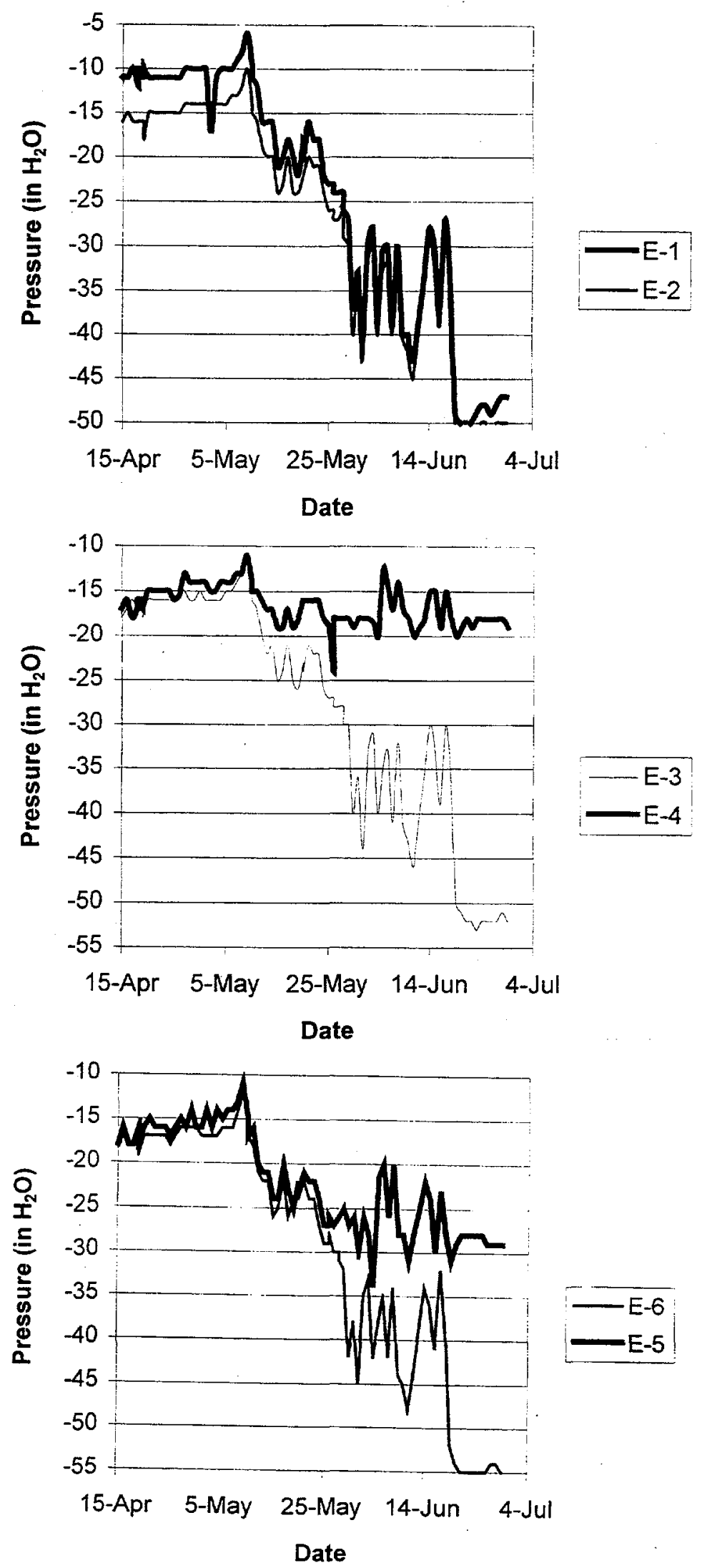

Figure 7.4. Differential Pressures Measured for Extraction Wells 
M1

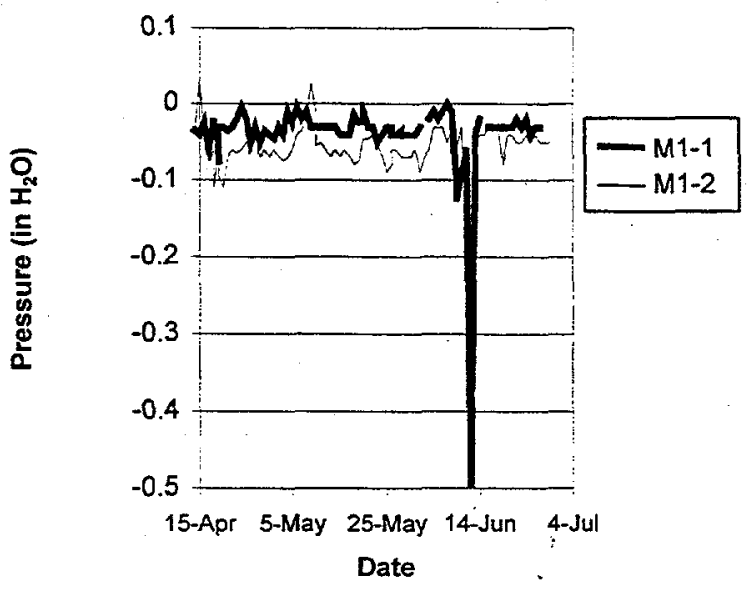

M3

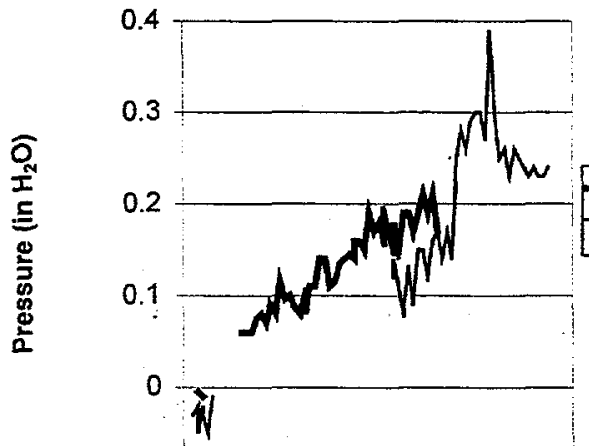

$-0.1$

15-Apr 5-May 25-May 14-Jun 4-Jul

Date

M5 and M6

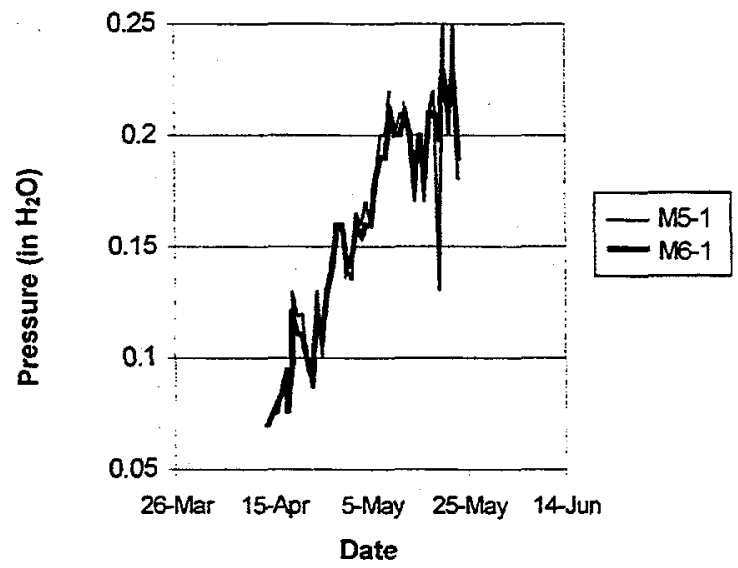

M2

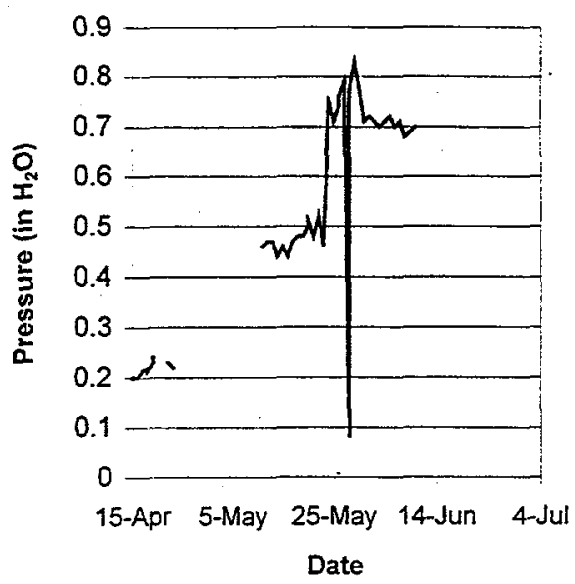

M4

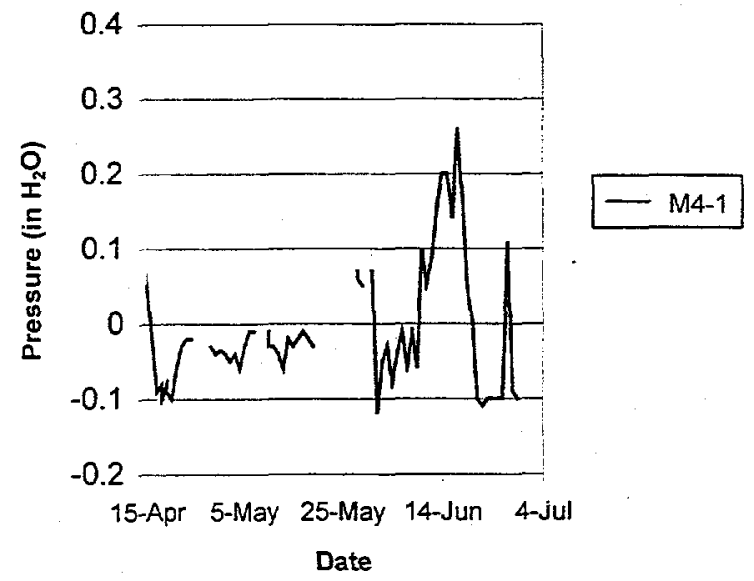

M7

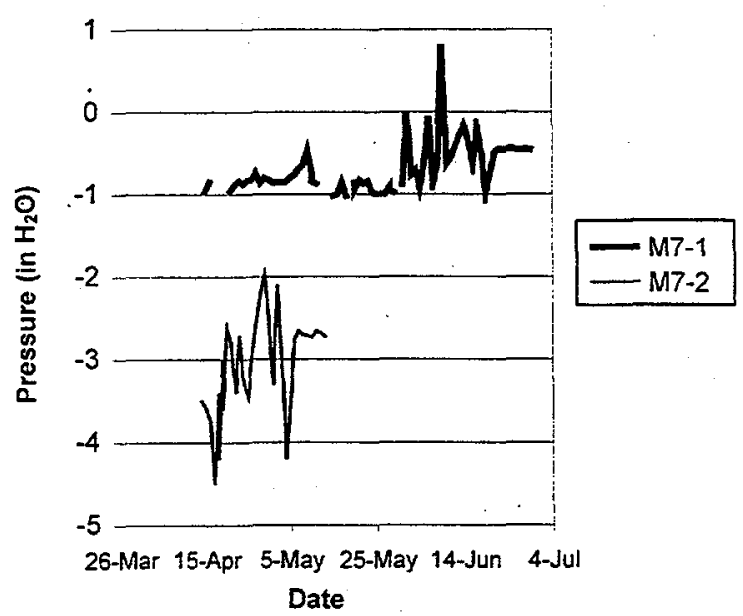

Figure 7.5. Differential Pressures Measured at Soil-Gas-Sampling Points 
times during the test. Based on the above, soil-gas point M1, which was a multilevel completion, was under the influence of the extraction flow during most of the test. However, at several times during the test, M1-2 rose to a positive differential pressure, indicating the point was under the influence of the injection flow. Soil-gas point M2 was found to be under a positive differential pressure throughout the test, indicating the soil-gas point was influenced by injection flow throughout the test. Soil-gas point M3 was a two-level completion and was under the influence of the injection flow throughout the test. As the test proceeded, the differential pressure continued to increase. The trend plot for M3-1 showed a higher pressure, compared to M3-2. However, during early June, the differential pressure at M3-1 exceeded the range of the magnehelic gauge and no further data were taken. Soil-gas point M4-1 was a single-level completion in the upper sediment horizon of the site. This site was under the influence of both the injection and extraction flows during different periods of the test. Soil-gas points M5 and M6 had very similar behavior and were under the influence of the injection flow throughout the test. There was an increasing trend as the test proceeded, suggesting an ever-increasing influence from the injection flow. As with M3-1, the differential pressure exceeded the upper limits of both the magnehelic gauge midway through the test and no further data were taken. Soil-gas point M7 was a two-level completion. Both levels were mostly under the influence of the extraction flow. However, M7-1 came under the influence of the injection flow during the middle of June. When comparing M7-1 and M7-2, M7-1 was higher in differential pressure, suggesting greater influence from the injection flow.

\subsubsection{Well-Field Treatment Gas Concentrations and Breakthrough Monitoring}

$\mathrm{H}_{2} \mathrm{~S}$ concentration data for the injection and extraction wells and soil points are presented in Table 7.3. An injection concentration of $\sim 200 \mathrm{ppm}_{\mathrm{v}} \mathrm{H}_{2} \mathrm{~S}$ in air was maintained throughout the treatment portion of the test. This was monitored by measurement of $\mathrm{H}_{2} \mathrm{~S}$ in the injection line and controlled by adjustment of a rotameter associated with the gas cylinder. Fluctuations of injection-gas concentration are attributed primarily to daytime and nighttime temperatures at the site. These fluctuations resulted in vapor-pressure changes within the liquefied $\mathrm{H}_{2} \mathrm{~S}$ cylinder and, hence, variations in gas-feed rates. These variations were generally not excessive and could be fairly well controlled by making occasional adjustments to the rotameter.

Breakthrough of $\mathrm{H}_{2} \mathrm{~S}$ at the extraction wells took longer than had been predicted from the laboratory treatability tests. Detectable levels of $\mathrm{H}_{2} \mathrm{~S}$ were observed late in the test, though at levels significantly below those expected.

The concentration of $\mathrm{H}_{2} \mathrm{~S}$ was also generally low for the soil-point measurements, except for point 2-1 (see Table 7.3). This point is located near the injection well and, thus, a higher concentration was expected. In addition, a relatively high pressure for this point (see Table 7.2) may indicate preferential movement of treatment gas through this portion of the field. 
Table 7.3. Well-Field Hydrogen Sulfide Concentrations

\begin{tabular}{|c|c|c|c|c|c|c|c|c|c|c|c|c|c|c|c|c|c|c|}
\hline \multirow{2}{*}{$\begin{array}{c}\text { Date } \\
(1998)\end{array}$} & \multirow[b]{2}{*}{ Time } & \multirow[b]{2}{*}{ IGRS-1 } & \multicolumn{6}{|c|}{ Extraction Wells $\left(\mathrm{ppm}_{\mathrm{v}}\right)$} & \multicolumn{10}{|c|}{ Soil-Gas-Sampling Points $\left(\mathrm{ppm}_{\mathrm{v}}\right)$} \\
\hline & & & E-1 & $E-2$ & $E-3$ & $E-4$ & E-5 & E-6 & $1-1$ & $1-2$ & $2-1$ & $3-1$ & $3-2$ & 4-1 & $6-1$ & $5-1$ & $7-2$ & $7-1$ \\
\hline $4 / 14$ & 1550 & Air & - & - & 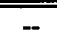 & - & - & - & - & - & $\overline{-}-$ & 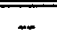 & $-\ldots$ & ב- & $\overline{--}$ & $\overline{-}-$ & 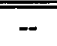 & 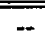 \\
\hline $4 / 15$ & 0840 & Air & - & - & - & - & - & - & - & - & - & -- & $\cdots$ & - & - & - & $\cdots$ & - \\
\hline $4 / 16$ & 0830 & Air & - & $\ldots$ & - & -- & -- & $\cdots$ & - & - & - & - & - & $\cdots$ & - & - & -- & - \\
\hline $4 / 17$ & 0850 & Air & - & - & - & -- & - & - & - & -- & - & - & -- & - & -- & - & -- & - \\
\hline $4 / 18$ & 0815 & Air & - & - & - & -- & - & $\cdots$ & -- & -- & -- & - & -- & 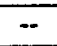 & - & -- & - & - \\
\hline $4 / 18$ & 1605 & 188 & -- & - & - & 0 & - & -- & - & - & - & - & - & - & - & - & - & - \\
\hline $4 / 19$ & 0125 & - & -- & 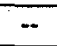 & - & -- & - & - & -- & - & -- & -- & - & - & - & - & $\cdots$ & - \\
\hline $4 / 19$ & 0803 & $30-199$ & -- & - & -- & 0 & -- & -. & - & $\cdots$ & -- & - & - & - & - & - & - & - \\
\hline $4 / 19$ & 1528 & $>240-210$ & 0 & 0 & 0 & -1 & 0 & 0 & - & - & -- & $\cdots$ & - & - & - & - & -- & - \\
\hline $4 / 20$ & 0942 & $80-200$ & 0 & 0 & 0 & 0 & 1 & 1 & -- & - & -- & - & - & - & - & - & -- & -- \\
\hline $4 / 21$ & 0930 & $80-200$ & 0 & 0 & 0 & 0 & 0 & 0 & -- & - & - & -- & -- & - & - & - & - & - \\
\hline $4 / 22$ & 0958 & 190 & 0 & 0 & 0 & 0 & 0 & 0 & $\ldots$ & -- & -- & -- & - & -- & - & - & -- & - \\
\hline $4 / 23$ & 0900 & 170 & 0 & 1 & 1 & 0 & 0 & 0 & $-\cdot$ & -- & - & -- & -- & -- & - & - & - & - \\
\hline $4 / 24$ & 0930 & 200 & 0 & 1 & 0 & 0 & 0 & 0 & -- & - & - & -- & -- & - & - & - & - & - \\
\hline $4 / 25$ & 1345 & $>240-210$ & 0 & 0 & 0 & 0 & $\overline{0}$ & 0 & - & - & - & -- & -- & -- & - & -- & - & - \\
\hline $4 / 26$ & 1225 & 190 & 0 & 0 & 0 & 0 & 0 & 0 & -- & - & -- & - & -- & - & - & - & - & - \\
\hline $4 / 27$ & 0935 & $160-180$ & 0 & 0 & 0 & 0 & 0 & 0 & - & - & -- & - & -- & -- & -- & -- & - & - \\
\hline $4 / 28$ & 1420 & 230 & 0 & 0 & 0 & 0 & 0 & 0 & - & - & -- & - & -- & - & - & - & - & - \\
\hline $4 / 29$ & 0910 & $146-188$ & 0 & 0 & 0 & 0 & 0 & 1 & 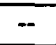 & -- & 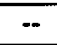 & -- & -- & $-\cdots$ & - & - & - & - \\
\hline $4 / 30$ & 1030 & $120-180$ & 2 & 1 & 1 & 1 & 1 & 0 & -- & -- & - & -- & -- & - & - & - & - & - \\
\hline $5 / 1$ & 0810 & $240-200$ & 1 & 0 & 0 & 0 & 0 & I & 0 & 0 & 0 & 0 . & 0 & 0 & 0 & 0 & 0 & 0 \\
\hline $5 / 2$ & 0935 & $173-198$ & 1 & 2 & 2 & 0 & 1 & 1 & - & -- & - & -- & -- & - & - & - & - & - \\
\hline $5 / 3$ & 1240 & $180-200$ & 0 & 0 & 0 & 0 & 1 & 0 & -- & -- & - & -- & - & - & -- & - & - & - \\
\hline $5 / 4$ & 0800 & $>240-224$ & 1 & 0 & 0 & 0 & 1 & 1 & -- & - & - & - & - & - & - & - & - & - \\
\hline $5 / 5$ & 0850 & 194 & 1 & 1 & 1 & 0 & 0 & 1 & -- & - & - & - & - & - & - & - & - & - \\
\hline $5 / 6$ & 0825 & $>240-207$ & 0 & 0 & 0 & 0 & 0 & $1-2$ & -- & - & - & - & - & - & - & - & -- & - \\
\hline $5 / 7$ & 1120 & $189-203$ & 0 & 0 & 0 & 2 & 0 & 0 & -- & - & - & - & - & - & - & $=$ & $\cdots$ & - \\
\hline $5 / 8$ & 0815 & $222-199$ & $0-1$ & $1-2$ & 1 & 0 & 0 & 1 & - & - & - & - & -- & -- & - & - & - & - \\
\hline $5 / 9$ & 1040 & $218-201$ & $0-1$ & 0 & & 1 & $0-1$ & 1 & - & - & - & - & - & 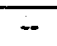 & - & -- & - & -- \\
\hline $5 / 10$ & 1330 & $178-200$ & 0 & 0 & 0 & 1 & 1 & 0 & - & - & - & - & $\ldots$ & $\ldots$ & $=$ & - & - & - \\
\hline $5 / 10$ & 1440 & -- & -- & - & - & -- & -- & - & -- & - & - & -- & - & - & - & - & - & - \\
\hline $5 / 11$ & 0903 & $220-202$ & 1 & 1 & 1 & $0-1$ & 0 & 0 & - & - & -- & - & -- & - & - & - & - & - \\
\hline $5 / 12$ & 1415 & 230 & 0 & 0 & 0 & 0 & 0 & 0 & - & -- & - & -- & - & - & - & - & - & - \\
\hline $5 / 13$ & 1025 & $>240-232$ & $\overline{0}$ & 0 & 0 & 0 & 0 & 0 & $=$ & -- & - & -- & - & - & -- & - & - & - \\
\hline $5 / 14$ & 0930 & 190 & $\overline{0}$ & 0 & 0 & 0 & 0 & 0 & $=$ & - & -- & - & - & - & - & - & - & - \\
\hline $5 / 15$ & 0900 & 208 & 0 & 0 & 0 & 0 & 0 & 0 & $\cdots$ & -- & - & - & - & - & - & -- & -- & - \\
\hline $5 / 16$ & 1348 & $160-188$ & 0 & 0 & 0 & 0 & 0 & 0 & - & - & - & - & - & - & $\cdots$ & $=$ & - & - \\
\hline $5 / 17$ & 1428 & 220 & 0 & 0 & 0 & 0 & 0 & 0 & - & - & $\cdots$ & - & -- & -- & -- & -- & - & - \\
\hline $5 / 18$ & 0915 & 237 & 0 & 0 & 0 & 0 & 0 & 0 . & - & - & - & -- & - & -- & -- & - & -- & - \\
\hline $5 / 19$ & 1002 & 230 & 0 & 0 & 0 & 0 & 0 & 0 & - & - & - & - & - & -- & - & - & - & - \\
\hline $5 / 20$ & 0802 & 215 & 0 & 0 & 0 & 0 & 0 & 0 & - & - & - & - & - & - & -- & - & -- & - \\
\hline $5 / 20$ & 1640 & 210 & - & -- & -- & -- & -- & $=$ & - & -- & -- & - & - & - & -- & - & - & - \\
\hline $5 / 21$ & 0957 & 240 & 0 & 0 & 0 & 0 & 0 & 0 & - & -- & 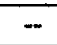 & -- & - & - & -- & - & - & - \\
\hline $5 / 22$ & 0905 & 181 & 0 & 0 & 0 & 0 & 0 & 0 & - & $\ldots$ & -- & -- & - & - & - & - & - & -- \\
\hline $5 / 23$ & 0839 & 215 & 0 & 0 & 0 & 0 & 0 & 0 & - & -- & -- & $\cdots$ & - & $\cdots$ & $\cdots$ & $\cdots$ & - & -- \\
\hline $5 / 24$ & 0913 & 200 & 0 & 0 & 0 & 0 & 0 & 0 & - & - & -- & -- & - & -- & -- & - & -- & - \\
\hline $5 / 25$ & 0950 & 206 & 0 & 0 & 0 & 0 & 0 & 0 & - & -- & $\cdots$ & 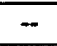 & - & $\cdots$ & $\cdots$ & -- & -- & - \\
\hline $5 / 26$ & 0915 & $204-227$ & 1 & 2 & 1 & 2 & 1 & 1 & - & - & - & - & - & -. & $\cdots$ & -- & - & - \\
\hline
\end{tabular}


Table 7.3. (contd)

\begin{tabular}{|c|c|c|c|c|c|c|c|c|c|c|c|c|c|c|c|c|c|c|}
\hline \multirow[b]{2}{*}{ Date } & \multirow[b]{2}{*}{ Time } & \multirow[b]{2}{*}{ IGRS-1 } & \multicolumn{6}{|c|}{ Extraction Wells $\left(\mathrm{ppm}_{\mathrm{v}}\right)$} & \multicolumn{10}{|c|}{ Soil-Gas-Sampling Points ( $\left.\mathrm{ppm}_{\mathrm{v}}\right)$} \\
\hline & & & E-1 & $\mathrm{E}-2$ & E-3 & $E-4$ & $\mathrm{E}-5$ & $E-6$ & $1-1$ & $1-2$ & $2-1$ & 3-1 & $3-2$ & $4-1$ & $6-1$ & $5-1$ & $7-2$ & $7-1$ \\
\hline $5 / 26$ & 1615 & - & - & -- & - & $\cdots$ & - & -- & - & - & -- & - & - & -- & $-\cdot$ & -- & - & -- \\
\hline $5 / 27$ & 0930 & $>240-233$ & 3 & 1 & 0 & 1 & 1 & 0 & -- & - & - & - & -- & - & -- & -- & - & -- \\
\hline $5 / 28$ & 0830 & $>240-229$ & 0 & 1 & 0 & 0 & 1 & 1 & -- & - & -- & -- & -- & - & -- & - & - & -- \\
\hline $5 / 28$ & 1600 & - & - & - & - & -- & - & -- & -- & - & -- & -- & - & - & -- & - & -- & - \\
\hline $5 / 29$ & 0930 & 224 & 0 & 0 & 0 & 0 & 0 & 0 & -- & - & - & -- & -- & - & - & - & -- & - \\
\hline $5 / 30$ & 0910 & 225 & 0 & 0 & 0 & 0 & 0 & 0 & 0 & 0 & 13 & 0 & 0 & 0 & 0 & 0 & 0 & 0 \\
\hline $5 / 31$ & 0940 & 224 & 0 & 1 & 0 & 0 & 0 & 0 & -- & - & - & - & -- & - & - & - & -- & -- \\
\hline $6 / 1$ & 0915 & 239 & 0 & 0 & 0 & 0 & 0 & 0 & $-\cdots$ & - & -- & - & - & - & - & - & - & -- \\
\hline $6 / 2$ & 1045 & 218 & 1 & 0 & 1 & 0 & 1 & 0 & -- & - & - & -- & - & - & -- & - & - & - \\
\hline $6 / 3$ & 0750 & $>240$ & 0 & 0 & 0 & 0 & 0 & 0 & 0 & 0 & 0 & 0 & 0 & 0 & 0 & 0 & 0 & 0 \\
\hline $6 / 4$ & 0630 & 231 & 0 & 0 & 0 & 0 & 0 & 0 & - & - & - & -- & - & - & -- & - & - & - \\
\hline $6 / 5$ & 0715 & 222 & 0 & 0 & 0 & 0 & 0 & 0 & 0 & 0 & 17 & 0 & 0 & 0 & 0 & 0 & 0 & 0 \\
\hline $6 / 6$ & 0800 & 220 & 0 & 0 & 0 & 0 & 0 & 0 & -- & - & -- & - & - & - & - & - & - & - \\
\hline $6 / 7$ & 0857 & $\geq 240$ & 0 & 0 & 0 & 0 & 0 & 0 & -- & -- & - & -- & - & - & - & - & - & - \\
\hline $6 / 8$ & 0750 & 233 & 1 & l & 0 & 0 & 0 & 0 & 0 & 0 & 20 & 0 & 0 & 0 & 0 & 0 & 0 & 0 \\
\hline $6 / 9$ & 0823 & 203 & 1 & 1 & 0 & 0 & 0 & 0 & 0 & 0 & 20 & 0 & 0 & 0 & 0 & 0 & 0 & 0 \\
\hline $6 / 10$ & 0825 & $170-206$ & 0 & 0 & 0 & 0 & 0 & 0 & - & -- & - & - & - & -- & - & -- & - & - \\
\hline $6 / 11$ & 1120 & $183-207$ & 0 & $0-1$ & 0 & $0-1$ & $0-1$ & $0-1$ & - & -- & - & - & -- & -- & - & - & - & - \\
\hline $6 / 12$ & 1010 & $218-232$ & 0 & 1 & 0 & 1 & 0 & 0 & 0 & 1 & 18 & 1 & 1 & 0 & 1 & 1 & $\mid$\begin{tabular}{|l|}
$0-1$ \\
\end{tabular} & $0-1$ \\
\hline $6 / 13$ & 0830 & $219-234$ & 0 & 0 & 0 & 0 & 0 & 1 & - & - & - & -- & -- & -- & - & - & -1 & - \\
\hline $6 / 14$ & 0750 & $>240-238$ & $2-3$ & 3 & $1-2$ & 1 & T & 4 & - & - & - & -- & -- & -- & - & -- & - & - \\
\hline $6 / 15$ & 0805 & $>240-205$ & 3 & 3 & 2 & 1 & 2 & 2 & -- & - & - & -- & - & -- & - & -- & - & 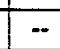 \\
\hline $6 / 16$ & 0630 & 210 & 2 & 2 & 1 & 2 & 1 & 1 & $\overline{1-2}$ & $0-1$ & 28 & 1 & $1-3$ & 1 & 2 & 2 & $2-3$ & 3 \\
\hline $6 / 17$ & 0815 & $240-191$ & 4 & 4 & 3 & 2 & 2 & 3 & -- & -- & -- & -- & - & -- & - & $\because$ & -- & - \\
\hline $6 / 18$ & 0805 & $242-209$ & 3 & 2 & 2 & 1 & 2 & 2 & 3 & 1 & 19 & $1-2$ & 2 & 1 & 3 & 3 & 1 & 2 \\
\hline $6 / 19$ & 1720 & 209 & 4 & 4 & 1 & 4 & 5 & 2 & -- & - & -- & - & - & -- & - & - & - & - \\
\hline $6 / 20$ & 0803 & $260-209$ & 3 & 5 & 2 & 2 & 3 & 3 & -- & - & - & - & -- & - & -- & -- & -- & -- \\
\hline $6 / 21$ & 0800 & 209 & 3 & 4 & 1 & $2-3$ & $3-5$ & 2 & 3 & 1 & 16 & 1 & 1 & 1 & 2 & 2 & 1 & 2 \\
\hline $6 / 22$ & $\overline{0818}$ & 213 & 6 & 4 & 4 & 2 & 2 & 4 & - & - & -- & - & - & - & -- & - & -- & -- \\
\hline $6 / 23$ & 1033 & $250-209$ & 3 & 7 & 2 & 3 & 4 & 3 & - & -- & -- & - & - & - & - & - & - & - \\
\hline $6 / 24$ & 0810 & $226-212$ & 3 & 5 & $2-3$ & 2 & 4 & 3 & $2-4$ & 1 & 33 & $1-4$ & $1-5$ & 2 & 3 & $1-4$ & $1-2$ & $1-4$ \\
\hline $6 / 25$ & 0815 & $224-209$ & $2-3$ & 6 & 2 & 2 & 3 & 2 & -- & -- & - & - & - & - & -- & - & - & - \\
\hline $6 / 26$ & 0723 & Air & 4 & 4 & 2 & 3 & 3 & 2 & $1-3$ & 1 & $1-3$ & $1-3$ & $1-4$ & 2 & 2 & $1-3$ & 2 & $2-4$ \\
\hline $6 / 27$ & 1033 & Air & 4 & 7 & 2 & 4 & 4 & 3 & - & - & - & - & - & - & $\cdots$ & - & $\cdots$ & - \\
\hline $6 / 28$ & 0910 & Air & $2-5$ & $1-6$ & 14 & $1-3$ & $2-5$ & $1-4$ & -- & -- & -- & - & - & -- & - & - & -- & - \\
\hline $6 / 29$ & 0835 & Air & $0-4$ & 1 & 1 & 1 & 1 & $1-2$ & - & - & - & - & - & - & - & - & -- & - \\
\hline
\end{tabular}


A problem encountered with obtaining gas-concentration measurements involved maintaining adequate sampling flow rates from the extraction wells and from those soil points that were under vacuum. The pump used was not powerful enough to maintain optimal flow rates for the sensors, particularly when the extraction wells were under higher vacuum late in the test. Specifically, a gas-flow rate of 300 to $500 \mathrm{~mL} / \mathrm{min}$ is needed to ensure optimal sensor performance. It is recommended that a more powerful pump be obtained for this activity in the future. An inline flow meter should also be used to ensure that adequate sampling flow rates are achieved.

\subsubsection{Environmental Monitoring and Alarm System Performance}

The environmental monitoring sensors performed in a generally acceptable manner during the test. Daily readings are presented in Table 7.4. This information illustrates that releases of $\mathrm{H}_{2} \mathrm{~S}$ to the environment during the test were not significant (i.e., concentrations were below the 8 -h permissible exposure limit of $10 \mathrm{ppm}_{\mathrm{v}}$ ).

Much of the variation of the data presented in Table 7.4 can be attributed to the effect of variations in air temperature on sensor response. The negative concentration readings present at the beginning of the test were associated with lower temperatures, whereas many of the higher readings were associated with higher daytime temperatures encountered later in the test. This effect is largely unavoidable, but not too significant. Generally, it is best to take readings in the morning and perform weekly sensor calibrations at that time. The sensors should also be shielded from direct sunlight.

A release of $\mathrm{H}_{2} \mathrm{~S}$ briefly occurred during initial hookup of the gas cylinder to the system. The amount

released, however, was not sufficient to activate the site monitoring alarms. Personnel were wearing selfcontained breathing apparatus during this operation and, thus, were not in danger. The release occurred because a gasket seal was not inserted into the gas-feed line. Addition of the gasket eliminated gas leakage.

The only alarm conditions experienced during the test were believed to be false. On two occasions, pager alarms were received in the early morning (see Table 7.4 comments). On arriving at the site, however, the alarms had reset themselves, and no $\mathrm{H}_{2} \mathrm{~S}$ was detected in the site environment. It was concluded that the false alarms were due to instabilities in the sensors that develop as the sensor element ages. This problem can be minimized or eliminated by replacing defective sensors. The need for sensor replacement can generally be identified by a deterioration in sensor response. The data logger was found to be especially useful for this purpose, when programmed to provide a record of individual sensor behavior. In particular, a failing sensor will exhibit baseline drift or erratic behavior in its record.

\subsection{Summary}

The gas-treatment system, well-field network, and environmental monitoring and alarm system performed as designed during the gas-treatment-injection test. A major achievement of the demonstration was the verification that in situ gaseous reduction can be performed in a safe and environmentally acceptable 
Table 7.4. Environmental Monitor Readings

\begin{tabular}{|c|c|c|c|c|c|c|}
\hline \multirow{2}{*}{$\begin{array}{c}\text { Date } \\
(1998)\end{array}$} & \multirow[b]{2}{*}{ Time } & \multicolumn{4}{|c|}{ Monitoring Points ( $\mathrm{ppm}_{\mathrm{v}}$ hydrogen sulfide) } & \multirow[b]{2}{*}{ Comments } \\
\hline & & M-1 & $\mathrm{M}-2$ & M-3 & $\mathrm{M}-4$ & \\
\hline $4 / 14$ & 1550 & -- & -- & 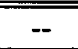 & -- & Initiated injection of air at 3:50 p.m. \\
\hline $4 / 15$ & 0840 & -4 & 0 & -4 & -4 & Instalied water knockout in scrubber sensor inlet line. \\
\hline $4 / 16$ & 0830 & -4 & 0 & -4 & -4 & \\
\hline $4 / 17$ & 0850 & 0 & 0 & 0 & - & \\
\hline $4 / 18$ & 0815 & 0 & 0 & -1 & 0 & Initiated $\mathrm{H}_{2} \mathrm{~S}$ injection at $10: 19$ a.m. \\
\hline $4 / 18$ & 1605 & 0 & 0 & 0 & 0 & \\
\hline $4 / 19$ & 0125 & 0 & 0 & -1 & 0 & \\
\hline $4 / 19$ & 0803 & 0 & 0 & -1 & 0 & \\
\hline $4 / 19$ & 1528 & 1 & 1 & 0 & 1 & $\mathrm{H}_{2} \mathrm{~S}$ turned off at 6:50 p.m. because of faulty sensor. \\
\hline $4 / 20$ & 0942 & 0 & 0 & -- & 0 & $\begin{array}{l}\text { Sensor replaced and } \mathrm{H}_{2} \mathrm{~S} \text { turned back on at } 9: 00 \text { a.m.; hose } \\
\text { attached to scrubber stack and directed into waste barrel. }\end{array}$ \\
\hline $4 / 21$ & 0930 & 0 & 0 & 0 & 0 & \\
\hline $4 / 22$ & 0958 & 0 & 0 & 0 & 0 & \\
\hline $4 / 23$ & 0900 & 0 & 0 & 0 & 0 & \\
\hline $4 / 24$ & 0930 & 0 & 0 & 0 & 0 & \\
\hline $4 / 25$ & 1345 & 0 & 0 & 0 & 0 & \\
\hline $4 / 26$ & 1225 & 0 & 0 & 0 & 0 & \\
\hline $4 / 27$ & 0935 & 0 & 0 & 0 & 0 & \\
\hline $4 / 28$ & 1420 & 0 & 0 & 0 & 0 & \\
\hline $4 / 29$ & 0910 & 0.7 & 0.3 & 0.0 & 0.1 & \\
\hline $4 / 30$ & 1030 & 1.0 & 0.8 & 0.1 & 0.5 & \\
\hline $5 / 1$ & 0810 & 0.7 & 1.0 & 0.0 & 0.0 & \\
\hline $5 / 2$ & 0935 & 1.0 & 0.2 & 1.1 & 0.0 & \\
\hline $5 / 3$ & 1240 & 1.4 & 1.4 & 0.8 & 0.7 & \\
\hline $5 / 4$ & 0800 & 0.7 & 0.3 & 0.0 & 0.0 & \\
\hline $5 / 5$ & 0850 & 0.5 & 0.0 & 0.0 & 0.0 & \\
\hline $5 / 6$ & 0825 & 0.5 & 0.0 & 0.0 & 0.0 & \\
\hline $5 / 7$ & 1120 & 0.9 & 0.2 & 0.0 & 0.1 & \\
\hline $5 / 8$ & 0815 & 0.5 & 0.3 & 0.0 & 0.0 & \\
\hline $5 / 9$ & 1040 & 0.8 & 0.0 & 0.0 & 0.0 & \\
\hline $5 / 10$ & 1330 & 1.0 & 0.3 & 0.0 & 0.5 & \\
\hline $5 / 10$ & 1440 & 1.1 & 0.3 & 0.0 & 0.9 & \\
\hline $5 / 11$ & 0903 & 0.6 & 0.0 & 0.0 & 0.0 & \\
\hline $5 / 12$ & 1415 & 0.7 & 0.0 & 0.1 & 0.0 & \\
\hline $5 / 13$ & 1025 & 0.8 & 0.0 & 0.0 & 0.0 & \\
\hline $5 / 14$ & 0930 & 0.7 & 0.2 & 0.0 & 0.1 & \\
\hline $5 / 15$ & 0900 & 0.5 & 0.2 & 0.0 & 0.0 & \\
\hline $5 / 16$ & 1348 & 1.1 & 0.7 & 0.4 & 0.8 & \\
\hline $5 / 17$ & 1428 & 1.5 & 0.5 & 0.9 & 1.7 & \\
\hline $5 / 18$ & 0915 & 0.8 & 0.6 & 0.0 & 0.1 & \\
\hline $5 / 19$ & 1002 & 1.0 & 0.1 & 0.0 & 0.2 & \\
\hline $5 / 20$ & 0802 & 0.5 & 0.2 & 0.0 & 0.0 & \\
\hline $5 / 20$ & 1640 & 1.3 & 0.5 & 0.4 & 1.0 & \\
\hline $5 / 21$ & 0957 & 0.7 & 0.1 & 0.0 & 0.3 & \\
\hline $5 / 22$ & 0905 & 0.5 & 0.0 & 0.0 & 0.0 & \\
\hline $5 / 23$ & 0839 & 0.5 & 0.3 & 0.0 & 0.0 & \\
\hline $5 / 24$ & 0913 & 0.6 & 0.3 & 0.0 & 0.0 & \\
\hline
\end{tabular}


Table 7.4. (contd)

\begin{tabular}{|c|c|c|c|c|c|c|}
\hline \multirow{2}{*}{$\begin{array}{c}\text { Date } \\
(1998)\end{array}$} & \multirow[b]{2}{*}{ Time } & \multicolumn{4}{|c|}{ Monitoring Points $\left(\mathrm{ppm}_{\mathrm{v}}\right.$ hydrogen sulfide) } & \multirow[b]{2}{*}{ Comments } \\
\hline & & $M-1$ & $\mathrm{M}-2$ & $\mathrm{M}-3$ & $\mathrm{M}-4$ & \\
\hline $5 / 25$ & 0950 & 0.5 & 0.0 & 0.0 & 0.0 & \\
\hline $5 / 26$ & 0915 & 0.5 & 0.1 & 0.0 & 1.0 & \\
\hline $5 / 26$ & 1615 & 1.1 & 0.3 & 1.1 & 2.2 & \\
\hline $5 / 27$ & 0930 & 0.6 & 0.2 & 0.0 & 1.1 & \\
\hline $5 / 28$ & 0830 & 0.5 & 0.1 & 0.0 & 0.5 & \\
\hline $5 / 28$ & 1600 & -. & - & -- & $\ldots$ & \\
\hline $5 / 29$ & 0930 & 0.6 & 0.2 & 0.0 & 1.1 & \\
\hline $5 / 30$ & 0910 & 0.7 & 0.7 & $\overline{0.0}$ & 1.1 & \\
\hline $5 / 31$ & 0940 & 0.9 & 0.8 & 0.0 & 1.3 & \\
\hline $6 / 1$ & 0915 & 0.7 & 0.7 & 0.0 & 1.1 & \\
\hline $6 / 2$ & 1045 & 1.2 & 0.8 & 0.4 & 1.6 & \\
\hline $6 / 3$ & 0750 & 0 & 0.3 & 0 & 0.8 & Shaded sensors to prevent overheating and reset. \\
\hline $6 / 4$ & 0603 & 0 & 0 & 0 & 0 & $\begin{array}{l}\text { Received false alarm at 3:30 a.m.; appears that sensor \#3 is } \\
\text { unstable. }\end{array}$ \\
\hline $6 / 5$ & 0715 & 0 & 0 & 0 & 0 & Installed new sensor at position 3 . \\
\hline $6 / 6$ & 0800 & 0 & 0 & 0 & 0 & \\
\hline $6 / 7$ & 0857 & 0 & 0 & 0.5 & 0.6 & \\
\hline $6 / 8$ & 0750 & 0 & 0 & 0.3 & 0.4 & \\
\hline $6 / 9$ & 0823 & 0 & 0 & 0 & 0.5 & Checked for $\mathrm{H}_{2} \mathrm{~S}$ under cover; measured $2 \mathrm{ppm}$. \\
\hline $6 / 10$ & 0825 & 0 & 0 & 0 & 0.2 & \\
\hline $6 / 11$ & 1120 & 0 & 0 & 0 & 0.7 & \\
\hline $6 / 12$ & 1010 & $0.0-0.1$ & 0 & -- & $0.8-0.9$ & $\begin{array}{l}\text { Noted that sensor readings increased somewhat by } 4: 20 \text { p.m. } \\
\text { (temperature } 95^{\circ} \mathrm{F} \text { ). }\end{array}$ \\
\hline $6 / 13$ & 0830 & 0.1 & 0 & 0.6 & 0.7 & \\
\hline $6 / 14$ & 0750 & 0 & 0 & 0.2 & 0.3 & \\
\hline $6 / 15$ & 0805 & 0 & $0.0-1.0$ & 0.2 & 0.2 & Sensor \#2 appears to be cycling. \\
\hline $6 / 16$ & 0630 & 0 & 0 & 0 & 0.3 & $\begin{array}{l}\text { False alarm occurred at 3:50 a.m.; appears that sensor } \# 2 \text { is } \\
\text { going bad. }\end{array}$ \\
\hline $6 / 17$ & 0815 & 1 & 0 & 0.2 & 0.4 & \\
\hline $6 / 18$ & 0805 & 0 & 0 & 0 & 0.2 & $\begin{array}{l}\text { Reviewed data logger; sensor } \# 2 \text { maxed at } 2.7 \mathrm{ppm} \mathrm{H}_{2} \mathrm{~S} \text { at } \\
\text { 3:50 a.m.; others indicate no } \mathrm{H}_{2} \mathrm{~S} \text {. }\end{array}$ \\
\hline $6 / 19$ & 1720 & 0.9 & 0 & 2 & 1.9 & Sensor $\# 2$ reading is unstable (drifting). \\
\hline $6 / 20$ & 0803 & 0.1 & 0.4 & 0 & 0.2 & $\begin{array}{l}\text { Data logger indicates that } \# 2 \text { averages } \sim 0 \mathrm{ppm} \mathrm{H}_{2} \mathrm{~S} \text { but } \\
\text { occasionally spikes (to } 8.6 \mathrm{max} \text { ). }\end{array}$ \\
\hline $6 / 21$ & 0800 & 0.1 & 0.6 & 0 & 0.3 & \\
\hline $6 / 22$ & 0818 & 0.4 & 1 & 0.6 & 0.6 & \\
\hline $6 / 23$ & 1033 & 0.5 & 0 & 0.8 & 1 & \\
\hline $6 / 24$ & 0810 & 0.1 & 0 & 0 & 0.4 & \\
\hline $6 / 25$ & 0815 & 0.3 & 0 & 0.2 & 0.6 & \\
\hline $6 / 26$ & 0723 & 0 & 0 & 0 & 0.3 & Purge initiated. \\
\hline $6 / 27$ & 1033 & -- & - & -- & - & $\begin{array}{l}\text { Environmental sensors turned off during purge, personal } \\
\text { sensors verified no } \mathrm{H}_{2} \mathrm{~S} \text { in site atmosphere. }\end{array}$ \\
\hline $6 / 28$ & 0910 & - & - & -- & - & \\
\hline $6 / 29$ & 0835 & - & - & - & -- & Purge ended at 11:00 a.m.; system shut down. \\
\hline
\end{tabular}


manner. Specific recommendations are discussed above that can readily be incorporated into future field testing or deployment activities to further develop the technology. These primarily include modifications in the gas-sampling equipment and design changes in the gas scrubber.

Breakthrough of $\mathrm{H}_{2} \mathrm{~S}$ at low levels was achieved by the end of the test, thus indicating treatment completion. Section 8.0 presents the results of posttreatment soil characterization activities at the site. A quantitative evaluation of treatment effectiveness is addressed in Section 9.0, where a comparison of preand posttreatment $\mathrm{Cr}(\mathrm{VI})$ soil data is undertaken. 


\subsection{Posttreatment Site Characterization}

In July 1998, after completion of the gas-treatment-injection test, ${ }^{3}$ soil samples were collected from nine boreholes (BH1 through BH9), whose locations were presented in Figure 4.1. The primary objective of this activity was to obtain information regarding the concentrations of $\mathrm{Cr}(\mathrm{VI})$ remaining in site soils, which were obtained by the procedures described in Section 4.0. The $\mathrm{Cr}$ (VI) distribution and concentration levels were subsequently compared to determine the effectiveness of the gas-treatment test. The results of this performance evaluation are presented in Section 9.0.

Information collected from the posttreatment boreholes included geologic descriptions and chemical and geotechnical data. The information associated with geologic logging descriptions has been included in the site geologic summary in Section 4.1. Chemical data consisted primarily of Cr(VI) analyses, which are presented in Table 8.1 that were performed by Method 7196 (EPA 1992). A comparison of these results with the pretreatment $\mathrm{Cr}(\mathrm{VI})$ analyses (see Tables 4.1 and 4.2) reveals that most of the $\mathrm{Cr}(\mathrm{VI})$ was reduced during the gas-treatment demonstration (Section 9.0 gives a quantitative comparison). A modified EPA Appendix VIII list of constituents (40 CFR 261) was also analyzed for in a composite soil sample taken from BH9 ( 8 to $11 \mathrm{ft}$ below ground surface), as suggested by the New Mexico Environment Department. This included analysis of metals (Method 6010), volatiles (8260), semivolatiles (8270), hexavalent chromium (7196), organochlorine pesticides and polychlorinated biphenyls ( 8080 ), and mercury (7471) (all methods from EPA 1992). All analytical results for the BH9 composite sample were at or below detection limits, except for some of the metals. Metals or cations detected were aluminum $(4,120 \mathrm{mg} / \mathrm{kg})$, lead $(2.5 \mathrm{mg} / \mathrm{kg})$, barium $(71.5 \mathrm{mg} / \mathrm{kg})$, calcium $(240,000 \mathrm{mg} / \mathrm{kg})$, total chromium $(3.3 \mathrm{mg} / \mathrm{kg})$, total iron $(3,740 \mathrm{mg} / \mathrm{kg})$, magnesium $(22,800 \mathrm{mg} / \mathrm{kg})$, manganese $(127 \mathrm{mg} / \mathrm{kg})$, vanadium $(10.4 \mathrm{mg} / \mathrm{kg})$, and zinc $(10.6 \mathrm{mg} / \mathrm{kg})$.

Soil-moisture contents were also obtained on a number of posttest soil samples (see Table 8.1) using the protocols described in WHC (1990) and were also presented in Table 8.1. The primary purpose for obtaining soil-moisture contents of the posttreatment samples was to determine if lateral variations in moisture content developed as a result of gas injection (e.g., decreases of moisture content near the injection borehole). An examination of the results failed to reveal any significant lateral variations but a vertical trend is well defined (Figure 8.1). In particular, the average moisture of posttest samples (i.e., average moisture for samples collected at the same depth) ranged from 20.3 to $36.1 \mathrm{wt} \%$ and generally varied with the stratigraphic character of the site. Thus, posttest samples collected from the upper $5 \mathrm{ft}$ of the site contained moisture in the 20 to $27 \mathrm{wt} \%$ range, corresponding to the lower gypsum content associated with fill sediment. In the depth range from 7 to $13 \mathrm{ft}$, soil moisture averaged $\sim 35 \mathrm{wt} \%$. This reflects the high-gypsum content of the white sand interval. Average posttest soil-moisture contents decreased from 31 to $<29 \mathrm{wt} \%$ in the 15 - to 19 -ft interval, reflecting a decrease in gypsum and increase in clay in the brown sand layer with depth. A comparison of the pre- and posttest soil-moisture profiles presented in Figure 8.1 also indicates that soil-moisture variation did not greatly change at the site as a result of the gas-treatment demonstration.

${ }^{1}$ Thornton, EC, TJ Gilmore, and KB Olsen. 1998. Treatability test plan for the in situ gas treatment demonstration. Pacific Northwest National Laboratory, Richland, Washington. 
Table 8.1. Posttest Geochemical Data

\begin{tabular}{|c|c|c|c|c|c|c|c|}
\hline $\begin{array}{l}\text { Sampling } \\
\text { Location }\end{array}$ & Depth $(\mathrm{ft})$ & $\begin{array}{c}\mathrm{Cr}(\mathrm{VI}) \\
(\mathrm{mg} / \mathrm{kg})\end{array}$ & $\begin{array}{c}\text { Soil Moisture } \\
(w t \%)\end{array}$ & $\begin{array}{l}\text { Sampling } \\
\text { Location }\end{array}$ & Depth (ft) & $\begin{array}{c}\mathrm{Cr}(\mathrm{VI}) \\
(\mathrm{mg} / \mathrm{kg})\end{array}$ & $\begin{array}{l}\text { Soil Moisture } \\
\text { (wt\%) }\end{array}$ \\
\hline \multirow[t]{15}{*}{ BH1 } & 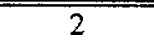 & 0.54 & -- & \multirow[t]{12}{*}{$\mathrm{BH} 3$ (contd) } & 11 & (-- & 35.6 \\
\hline & 4 & 4.5 & -- & & 12 & $<0.14$ & -- \\
\hline & 6 & 0.67 & -- & & $12 \mathrm{D}$ & $<0.13$ & -- \\
\hline & 8 & 0.95 & -- & & 13 & -- & 35.7 \\
\hline & 10 & $<0.13$ & $-\cdots$ & & 13.5 & $<0.13$ & - \\
\hline & 11 & -- & 34.6 & & 5 & -- & 34.3 \\
\hline & 12 & 14.3 & -- & & 16 & $<0.13$ & -- \\
\hline & 13 & - & 34.3 & & 17 & -- & 24.9 \\
\hline & 14 & 1.5 & -- & & 18 & $<0.13$ & -- \\
\hline & 15 & -- & 33.1 & & 19 & -- & 29.6 \\
\hline & 16 & $<0.13$ & -- & & 20 & $<0.13$ & - \\
\hline & 18 & $<0.13$ & -- & & & & \\
\hline & 20 & $<0.13$ & -- & \multirow[t]{18}{*}{$\mathrm{BH} 4$} & 2 & 0.27 & -- \\
\hline & & & & & 4.5 & 3.5 & - \\
\hline & & & & & 5 & -- & 26.3 \\
\hline \multirow[t]{21}{*}{$\overline{\mathrm{BH} 2}$} & 1 & -- & 20.8 & & 6 & 0.92 & -- \\
\hline & 2 & $<0.12$ & -- & & 7 & -- & 33.6 \\
\hline & 3 & -- & 19.3 & & 8 & $<0.13$ & -- \\
\hline & 4 & 0.47 & -- & & 9 & -- & 32.1 \\
\hline & 5 & -- & 26.2 & & 10 & $<0.13$ & -- \\
\hline & 6 & 4.6 & -- & & 11 & -- & 35.8 \\
\hline & 7 & $\cdots$ & 32.3 & & 12 & 7.4 & -- \\
\hline & 8 & $<0.13$ & -- & & 13 & - & 31.2 \\
\hline & 9 & -- & 37.8 & & 14 & 2.8 & - \\
\hline & 10 & $<0.14$ & -- & & 15 & - & 23.2 \\
\hline & 11 & -- & 36.3 & & 16 & 0.13 & - \\
\hline & 12 & 0.68 & -- & & 17 & - & 30.3 \\
\hline & 13 & -- & 34.4 & & 18 & $<0.12$ & - \\
\hline & 14 & $<0.13$ & -- & & 20 & 0.23 & - \\
\hline & 15 & -- & 27.4 & & & & \\
\hline & 16 & $<0.13$ & -- & \multirow[t]{16}{*}{ BH5 } & 2 & 0.23 & - \\
\hline & 17 & -- & 31.1 & & 4 & 1.2 & -- \\
\hline & 18 & $<0.13$ & -- & & 6 & 0.42 & -- \\
\hline & 19 & - & 30.1 & & 7 & -- & 37.6 \\
\hline & 20 & $<0.13$ & -- & & 8 & 1.9 & -- \\
\hline & & & & & 9 & -- & 40.6 \\
\hline \multirow[t]{10}{*}{$\overline{\mathrm{BH} 3}$} & 1 & -- & 23.2 & & 10 & $<0.14$ & - \\
\hline & 2 & $<0.12$ & -- & & 11 & -- & 35.9 \\
\hline & 3 & -- & 20.3 & & 12 & 10.5 & - \\
\hline & 4 & $<0.12$ & -- & & 13 & -- & 39.4 \\
\hline & 5 & - & 25.4 & & 14 & 6.5 & -- \\
\hline & 6 & 5.2 & -- & & 15 & -- & 29.3 \\
\hline & 7 & -- & 31.9 & & 16 & 0.58 & -- \\
\hline & 8 & $<0.13$ & -- & & 17 & -- & 30.8 \\
\hline & 9 & -- & 29.3 & & 18 & 0.62 & -- \\
\hline & 10 & 0.23 & -- & & 20 & 0.046 & -- \\
\hline
\end{tabular}


Table 8.1. (contd)

\begin{tabular}{|c|c|c|c|c|c|c|c|}
\hline $\begin{array}{l}\text { Sampling } \\
\text { Location }\end{array}$ & Depth $(\mathrm{ft})$ & $\begin{array}{c}\mathrm{Cr}(\mathrm{VI}) \\
(\mathrm{mg} / \mathrm{kg})\end{array}$ & $\begin{array}{l}\text { Soil Moisture } \\
\text { (wt\%) }\end{array}$ & $\begin{array}{l}\text { Sampling } \\
\text { Location }\end{array}$ & Depth $(\mathrm{ft})$ & $\begin{array}{c}\mathrm{Cr}(\mathrm{VI}) \\
(\mathrm{mg} / \mathrm{kg}) \\
\end{array}$ & $\begin{array}{l}\text { Soil Moisture } \\
\text { (wt\%) }\end{array}$ \\
\hline \multirow[t]{15}{*}{$\mathrm{BH} 6$} & 2 & 3.5 & -- & \multirow[t]{11}{*}{ BH8 (contd) } & 12 & $<0.13$ & - \\
\hline & 4 & 4 & - & & 13 & -- & 33.7 \\
\hline & 6 & 0.12 & -- & & 14 & 0.0093 & - \\
\hline & 8 & 1.8 & -- & & 15 & - & 36.3 \\
\hline & 9 & -- & 37.7 & & 16 & $<0.12$ & -- \\
\hline & 10 & 12.5 & -- & & $16 \mathrm{D}$ & $<0.13$ & $\because$ \\
\hline & 12 & 6.1 & -- & & 17 & -- & 30.5 \\
\hline & 13 & - & 35.3 & & 18 & $<0.12$ & -- \\
\hline & 14 & 1.2 & -- & & 19 & -- & 31.9 \\
\hline & 15 & -- & 38.5 & & 20 & $<0.13$ & -- \\
\hline & 16 & 0.032 & -- & & & & \\
\hline & 17 & -- & 34.6 & \multicolumn{2}{|c|}{ BH9 Composite } & $<0.13$ & -- \\
\hline & 18 & 0.19 & -- & & & & \\
\hline & 20 & $<0.13$ & -- & & & & \\
\hline & & & & & & & \\
\hline \multirow[t]{20}{*}{ BH7 } & 1 & -- & 22.9 & & & & \\
\hline & 2 & $<0.49$ & -- & & & & \\
\hline & 3 & - & 23.5 & & & & \\
\hline & 4 & $<0.50$ & -- & & & & \\
\hline & 5 & -- & 26.5 & & & & \\
\hline & 6 & $<0.52$ & -- & & & & \\
\hline & 7 & -- & 38.7 & & & & \\
\hline & 8 & $<0.53$ & - & & & & \\
\hline & 9 & -- & 34.4 & & & & \\
\hline & 10 & $<0.56$ & -- & & & & \\
\hline & 11 & - & 29.7 & & & & \\
\hline & 12 & $<0.54$ & -- & & & & \\
\hline & 13 & - & 35.6 & & & & \\
\hline & 14 & $<0.53$ & -- & & & & \\
\hline & 15 & -- & 28.6 & & & & \\
\hline & 16 & $<0.52$ & -- & & & & \\
\hline & 17 & -- & 18.2 & & & & \\
\hline & 18 & $<0.50$ & - & & & & \\
\hline & 19 & $-\cdot$ & 23.3 & & & & \\
\hline & 20 & $<0.53$ & -- & & & & \\
\hline \multirow{10}{*}{ BH8 } & 2 & $<0.11$ & -. & & & & \\
\hline & 3 & -- & 18.2 & & & & \\
\hline & 4 & 0.009 & - & & & & \\
\hline & 5 & - & 29.5 & & & & \\
\hline & 6 & 0.0094 & -- & & & & \\
\hline & 7 & - & 36.5 & & & & \\
\hline & 8 & 0.0096 & $\cdots$ & & & & \\
\hline & 9 & - & 40.6 & & & & \\
\hline & 10 & 0.12 & -- & & & & \\
\hline & 11 & -- & 32.2 & & & & \\
\hline
\end{tabular}


Pretest Moisture (IGRS-1)

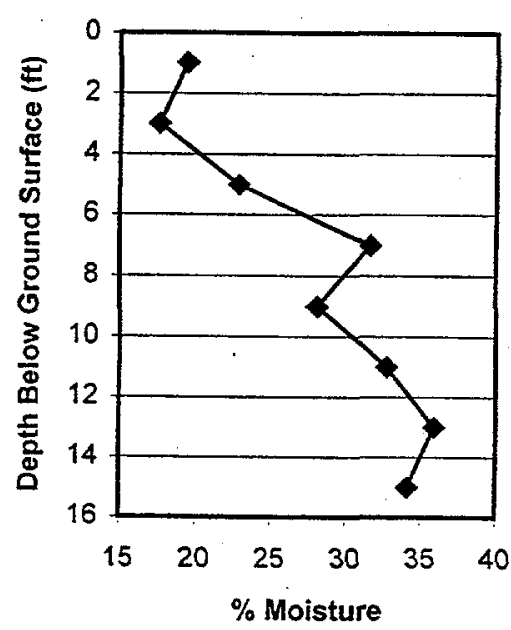

Posttest

Average Moisture

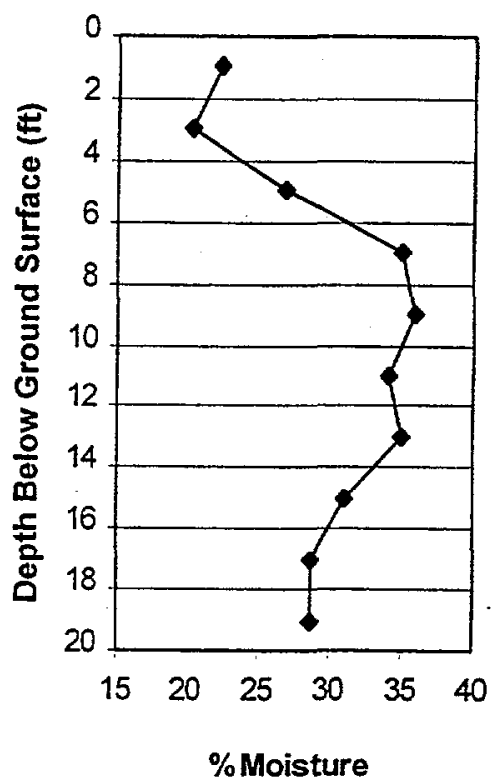

Figure 8.1. Depth Profiles of Soil-Moisture Contents for Pre- and Posttest Soil Samples 


\subsection{Technology Performance and Cost Evaluation}

An evaluation of the technical performance and cost of the IGRS approach is provided in this section. The technical performance is based primarily on a quantitative comparison of the reduction in $\mathrm{Cr}(\mathrm{VI})$ mass at the site. The cost analysis utilizes actual costs associated with the demonstration to construct a model that permits a comparison with the baseline technology.

\subsection{Technical Performance Evaluation}

\subsubsection{Hexavalent Chromium Mass Reduction Calculation}

The total mass of $\mathrm{Cr}(\mathrm{VI})$ in the soil at the test site was calculated for before and after the gas-injection test, and the results were compared to determine the mass of $\mathrm{Cr}$ (VI) reduced during the test. The $\mathrm{Cr}(\mathrm{VI})$ values used to calculate the mass were measured in samples collected from boreholes drilled at the site. A total of 9 boreholes were drilled and sampled at 2-ft intervals before the test and 8 boreholes were drilled and sampled at 2-ft intervals after the test (Tables 9.1 and 9.2).

For each 2-ft interval (e.g., surface to $2 \mathrm{ft}, 2$ to $4 \mathrm{ft}$, etc.), the data were plotted on a base map and gridded using the Kriging method (Figure 9.1). Kriging is a geostatistical gridding method proved useful in many aspects of geology, including mining and oil-reserve estimations. Kriging applies a weighting to each data point based on the overall trend of the data to produce contour maps; in this case, contours of $\mathrm{Cr}(\mathrm{VI})$ concentration. The contours were plotted using a contouring software (Surfer, Golden Software, Inc.). The area of each contour interval was then calculated using an area function in Surfer, and the volume was then determined by multiplying the area by the thickness ( $2 \mathrm{ft}$ ). The $\mathrm{Cr}(\mathrm{VI})$ mass present within each contour interval can then be determined by multiplying the volume by the concentration

Table 9.1. Hexavalent Chromium Data (mg/kg) used to Calculate Total Mass Present in Site Soils Before Test

\begin{tabular}{|l|c|c|c|c|c|c|c|c|c|}
\hline \multirow{2}{*}{ Borehole } & \multicolumn{10}{|c|}{ Depth (ft) } \\
\cline { 2 - 11 } & 2 & 4 & 6 & 8 & 10 & 12 & 14 & 16 & 18 \\
\hline IGRS-1 & 0.76 & 1.5 & 2.9 & 85 & 45 & 0.15 & 0 & 8 & 0 \\
\hline M1 & 0.06 & 0 & 0 & 0 & 0 & 0 & 0 & 0 & 0 \\
\hline M3 & 0 & 0 & 0 & 0 & 0.46 & 0 & 0 & 0 & 0 \\
\hline M7 & 0 & 0 & 15 & 13 & 0.21 & 0.04 & 0 & 0 & 0 \\
\hline GP1 & & & & 0.47 & 0.47 & & & 1.3 & \\
\hline GP2 & & 0.16 & & 10 & 0.53 & 0.12 & & & 0.19 \\
\hline GP3 & & & & 0.041 & 0.16 & 0.16 & 0.082 & & 0.065 \\
\hline GP4 & & & & 1.2 & 7.6 & 7.6 & 1.1 & & 2.4 \\
\hline GP5 & & 0.37 & & 21 & 22 & & 7.7 & & 1.9 \\
\hline
\end{tabular}


Table 9.2. Hexavalent Chromium Data $(\mathrm{mg} / \mathrm{kg})$ used to Calculate Total Mass Present in Site Soils After Test

\begin{tabular}{|l|c|c|c|c|c|c|c|c|c|}
\hline \multirow{3}{*}{ Borehole } & \multicolumn{10}{|c|}{ Depth (ft) } \\
\cline { 2 - 11 } & 2 & 4 & 6 & 8 & 10 & 12 & 14 & 16 & 18 \\
\hline \hline $\mathrm{BH} 1$ & 0.54 & 4.5 & 0.67 & 0.95 & 0.95 & 14.3 & 1.5 & 0.06 & 0.06 \\
\hline $\mathrm{BH} 2$ & 0.06 & 0.47 & 4.6 & 0.06 & 0.06 & 0.68 & 0.06 & 0.06 & 0.06 \\
\hline $\mathrm{BH} 3$ & 0.06 & 0.06 & 5.2 & 0.06 & 0.06 & 0.07 & 0.06 & 0.06 & 0.06 \\
\hline $\mathrm{BH} 4$ & 0.27 & 3.5 & 0.92 & 0.06 & 0.06 & 7.4 & 2.8 & 0.06 & 0.06 \\
\hline $\mathrm{BH} 5$ & 0.23 & 1.2 & 0.42 & 1.9 & 1.9 & 10.5 & 6.5 & 0.58 & 0.62 \\
\hline $\mathrm{BH} 6$ & 3.5 & 4 & 0.12 & 1.8 & 1.8 & 6.1 & 1.2 & 0.032 & 0.19 \\
\hline $\mathrm{BH} 7$ & 0.24 & 0.25 & 0.26 & 0.26 & 0.26 & 0.26 & 0.26 & 0.26 & 0.25 \\
\hline $\mathrm{BH} 8$ & 0.05 & 0.009 & 0.0094 & 0.0096 & 0.12 & 0.06 & 0.009 & 0.06 & 0.06 \\
\hline
\end{tabular}

(given in weight/volume) of each contour interval. Finally, the mass of each contour interval was summed for a total mass for that depth range (e.g., surface to $2 \mathrm{ft}, 2$ to $4 \mathrm{ft}$, etc.) and then each depth range was summed for a total mass (Table 9.3). This method was applied for both the before and after $\mathrm{Cr}$ (VI) concentrations.

The results of the mass calculation presented in Table 9.3 indicate that $70 \%$ of the original Cr(VI) mass present at the site was reduced during the gas-injection test. The mass of $\mathrm{Cr}$ (VI) present before and after gas treatment of the site is also presented in Figure 9.2 as a function of depth. This figure illustrates that nearly all of the $\mathrm{Cr}(\mathrm{VI})$ in the interval from 4 to $10 \mathrm{ft}$ was reduced. In this interval, average $\mathrm{Cr}(\mathrm{VI})$ decreased from $\sim 8.1 \mathrm{mg} / \mathrm{kg}$ before treatment to $1.14 \mathrm{mg} / \mathrm{kg}$ after treatment (see Table 9.1 ). This zone corresponds to the white sand interval and contained the highest concentrations of $\mathrm{Cr}(\mathrm{VI})$. In the 10 - to 16- $\mathrm{ft}$ range, which corresponds to the brown sand, it appears that the $\mathrm{Cr}$ (VI) mass did not change

Table 9.3. Mass Calculations of Hexavalent Chromium Before and After Gas Injection

\begin{tabular}{|c|c|c||}
\hline Depth (Ft) & $\mathrm{Cr}(\mathrm{VI})$ Before $(\mathrm{g})$ & $\mathrm{Cr}(\mathrm{VI})$ After $(\mathrm{g})$ \\
\hline $0-2$ & 13.46 & 26.71 \\
\hline $2-4$ & 22.96 & 59.4 \\
\hline $4-6$ & 233.02 & 85.94 \\
\hline $6-8$ & 818.42 & 22.15 \\
\hline $8-10$ & 242.56 & 52.44 \\
\hline $10-12$ & 78.74 & 142.19 \\
\hline $12-14$ & 59.61 & 63.96 \\
\hline $14-16$ & 85.45 & 4.4 \\
\hline $16-18$ & 9.97 & 5.52 \\
\hline Total & $1,564.21$ & 462.74 \\
\hline
\end{tabular}



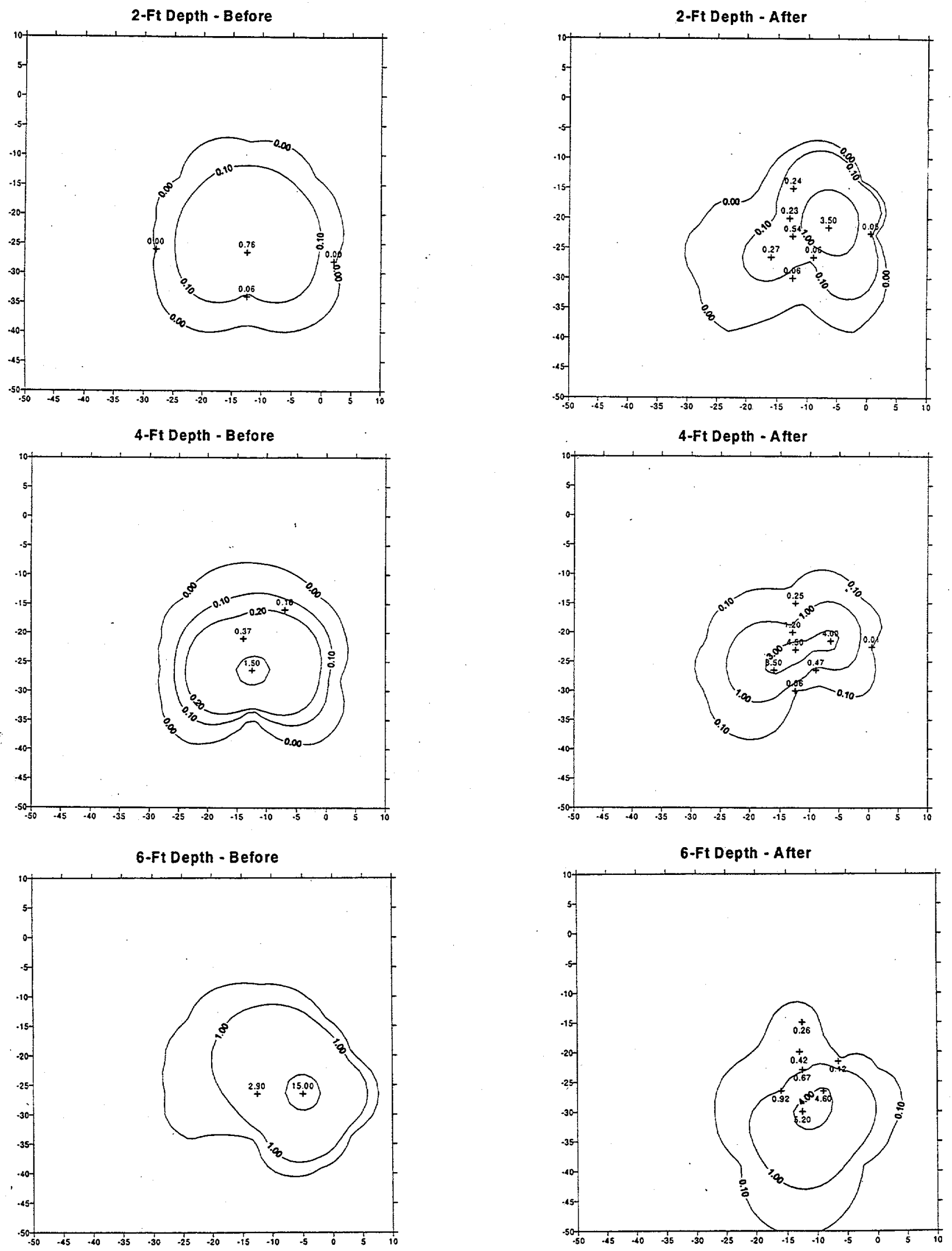

Figure 9.1. Distribution of Hexavalent Chromium Prior and Subsequent to Gas Treatment 

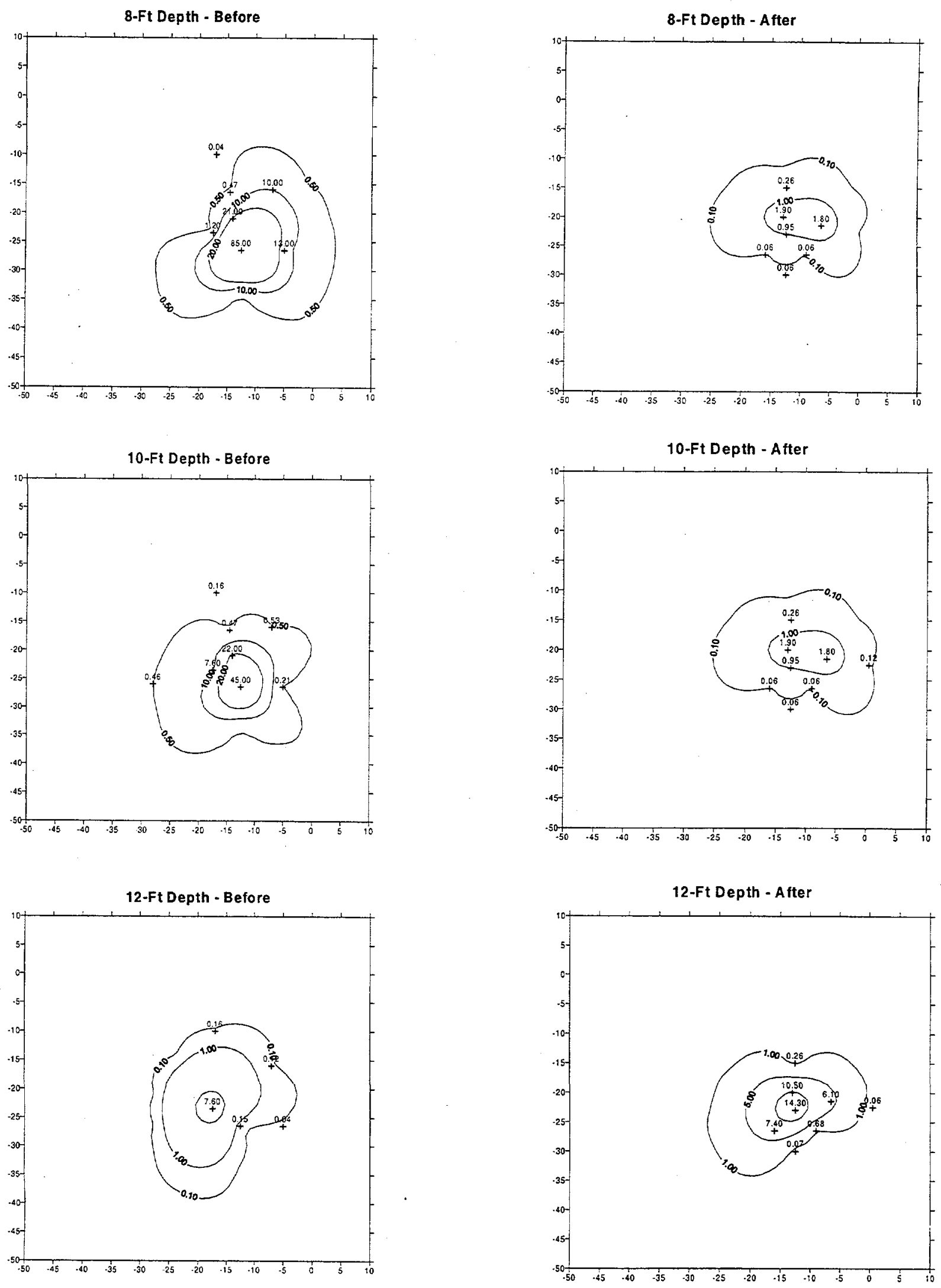

Figure 9.1. (contd)

$$
9.4
$$


14-Ft Depth - Before

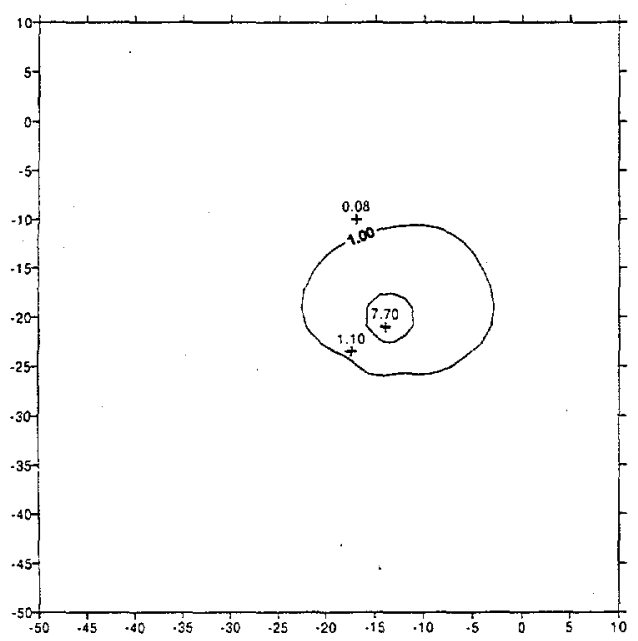

16-Ft Depth - Before

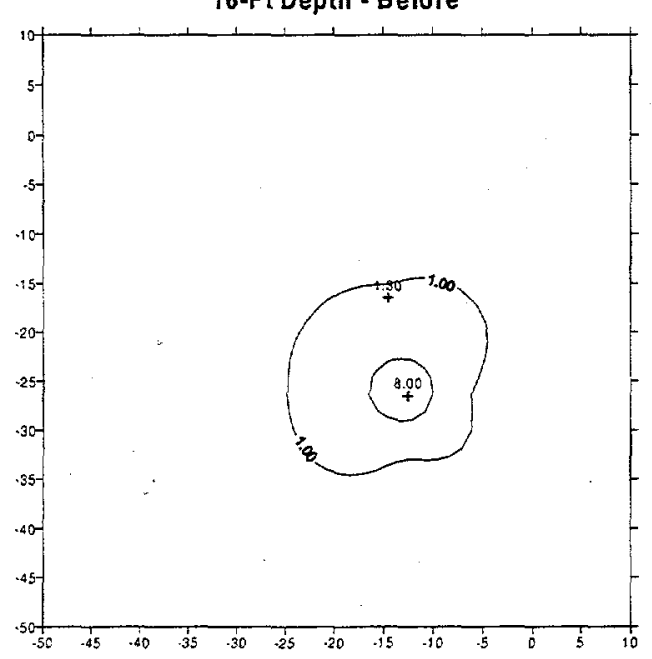

18-Ft Depth - Before

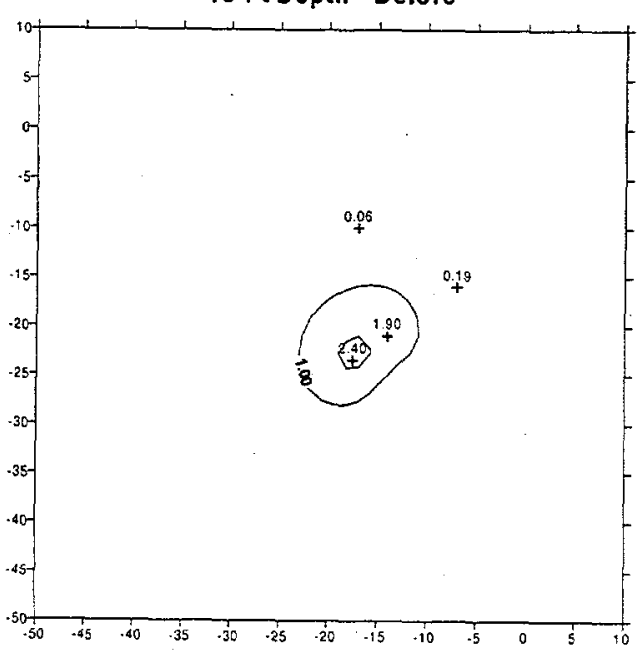

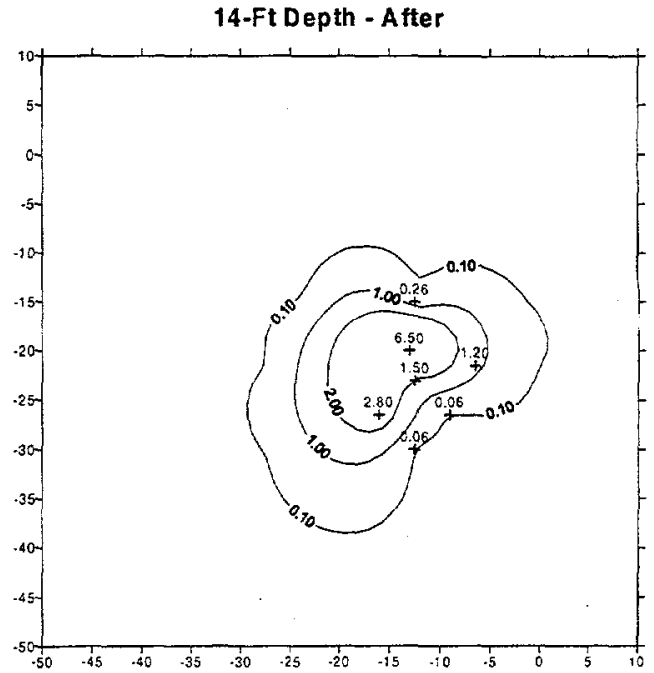
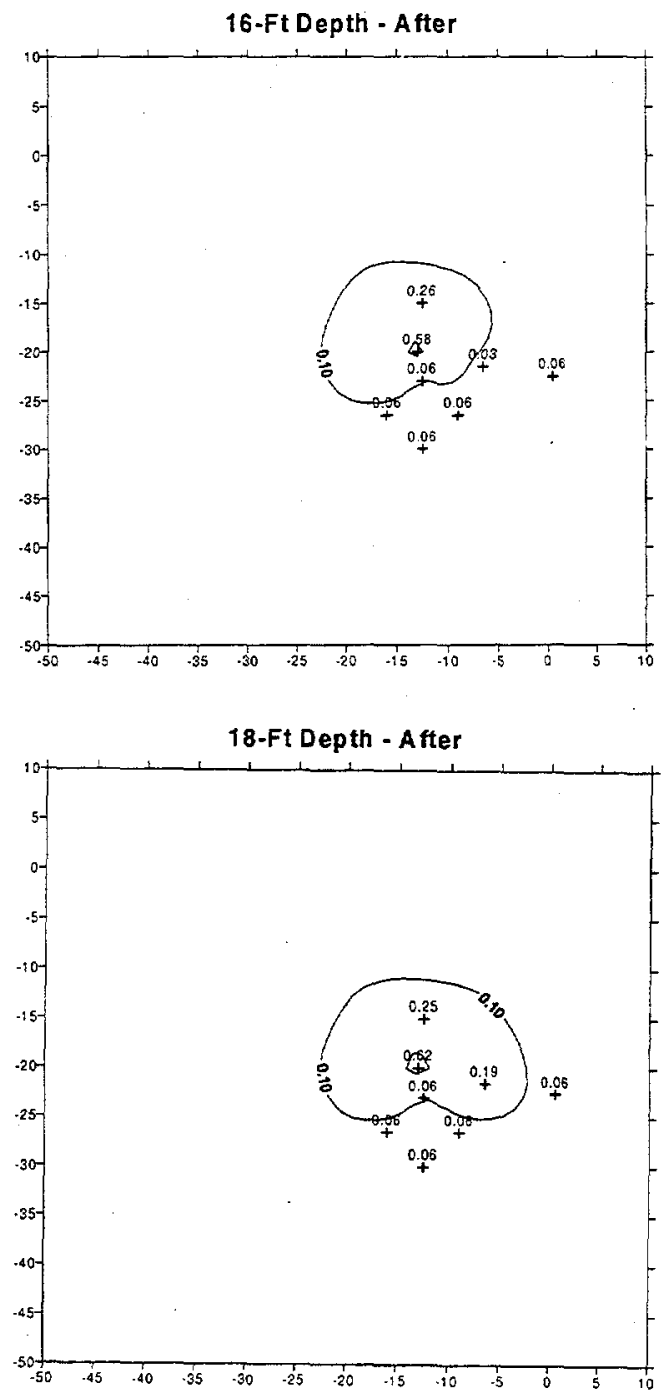

Figure 9.1. (contd) 


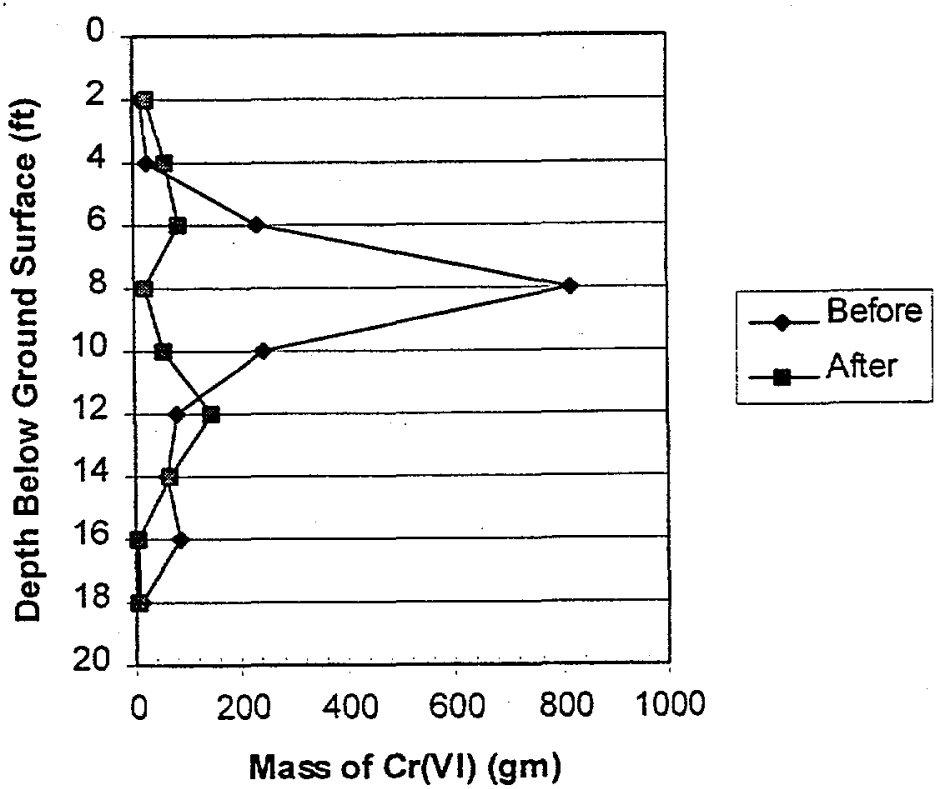

Figure 9.2. Mass of Hexavalent Chromium Versus Depth Before and After Gas Treatment

appreciably and the average concentration of $\mathrm{Cr}(\mathrm{VI})$ remained $\sim 2 \mathrm{mg} / \mathrm{kg}$. These results suggest that the treatment gas mixture was largely channeled through the white sand interval, which is characterized by higher permeability. The lower brown sand zone appears to have been bypassed, apparently because of lower permeability.

A discrepancy was observed in this analysis, in that the mass of $\mathrm{Cr}(\mathrm{VI})$ calculated for several layers appeared to be greater after treatment than before (i.e., the 0- to 2-, 2- to 4-, 10- to 12-, and 12- to 14-ft intervals). To better evaluate this discrepancy, a sensitivity analysis was performed wherein a variety of contouring methods were utilized for calculating the mass of $\mathrm{Cr}$ (VI). These methods included inverse distance squared, kriging with a linear variogram, radial basis method, and Shepard's method. Of these methods, kriging and radial basis came closest to honoring the data, whereas inverse distance and Shepard's produced contouring results that did not correspond to the conceptual model. Kriging and radial basis also demonstrated a good correspondence in terms of evaluation of the mass of $\mathrm{Cr}$ (VI) associated with individual layers. It was therefore concluded that contouring variations associated with the use of kriging was not the source of the observed discrepancy.

It is concluded that the source of the discrepancy can be attributed to the number and spatial placement of the sampling boreholes (i.e., the number of boreholes and samples collected were not sufficient from a statistical standpoint to define adequately the total mass of $\mathrm{Cr}$ in the layers having lower levels of $\mathrm{Cr}[\mathrm{VI}])$. In the 0 - to 2 -ft interval, for example, the mass calculation was driven primarily by one sample that showed a high result in the after-test samples (see Figure 9.1). This inherent variability exists because $\mathrm{Cr}(\mathrm{VI})$ was not evenly distributed across the site and also because the before and after boreholes were not located in the same positions. From a practical standpoint, however, 17 boreholes are generally considered a large sampling effort for a site with an aerial extent of $<50$ by $50 \mathrm{ft}$. In addition, the level of error is considered to be low enough to not affect the conclusion that $\sim 70 \%$ of the $\mathrm{Cr}$ (VI) present at the site was reduced during the demonstration. 


\subsubsection{Consumption of Hydrogen Sulfide During Soil-Treatment Demonstration}

The amount of $\mathrm{H}_{2} \mathrm{~S}$ used in the demonstration exceeded the estimate of $0.00004 \mathrm{lb} / \mathrm{lb}$ of soil obtained as a result of the laboratory treatability tests. Specifically, the entire $60-\mathrm{lb}$ cylinder of $\mathrm{H}_{2} \mathrm{~S}$ was used instead of the predicted $36.5 \mathrm{lb}$, thus indicating $\sim 0.000066 \mathrm{lb}$ of $\mathrm{H}_{2} \mathrm{~S}$ was applied to each pound of soil within the flow cell. Moreover, the concentration levels of $\mathrm{H}_{2} \mathrm{~S}$ attained in the extraction wells were relatively low. Adequate treatment was nevertheless achieved at the site within the white sand zone.

Future laboratory work is planned to investigate the nature of the chemical reactions and associated reaction rates that are important in gaseous reduction of $\mathrm{Cr}(\mathrm{VI})$ in soils. In particular, it is inferred that catalytic effects may be present, whereby the soil matrix greatly accelerates the oxidation of $\mathrm{H}_{2} \mathrm{~S}$ by air as indicated by the reaction:

$$
\mathrm{H}_{2} \mathrm{~S}+2 \mathrm{O}_{2} \rightarrow \mathrm{SO}_{4}^{2-}+2 \mathrm{H}^{+}
$$

This process could provide an explanation for the limited breakthrough of $\mathrm{H}_{2} \mathrm{~S}$ in the extraction wells during the demonstration. Alternatively, slow reactions between $\mathrm{H}_{2} \mathrm{~S}$ and ferric oxyhydroxide phases may explain the delay in breakthrough and the low breakthrough concentrations observed. Elucidation of these processes should allow a more accurate estimate to be provided of the amount of $\mathrm{H}_{2} \mathrm{~S}$ required in the field and possibly also suggest methods for improving the effectiveness and reducing the unit costs of the technology.

\subsection{Cost Analysis}

A life-cycle cost model was developed for the IGRS approach based on information collected during the demonstration (Hogan 1998). This spreadsheet model provides an estimate of project and unit costs for technology implementation through user input of site-specific data. The model also provides an estimate of baseline excavation costs for comparison.

The variation in unit cost of the technology with varying model inputs was discussed by Hogan (1998). The model inputs investigated included vadose-zone plume size, amount of $\mathrm{H}_{2} \mathrm{~S}$ required per pound of soil, radius of influence of well-field boreholes, and well-drilling and -installation costs. In one example, a unit cost of $\$ 43 / \mathrm{yd}^{3}$ was obtained for in situ gaseous reduction versus $\$ 214 / \mathrm{yd}^{3}$ for excavation. In this example, it was assumed that the area of the plume was 125 by $90 \mathrm{ft}$ and extended to a depth of $45 \mathrm{ft}, 0.00004 \mathrm{lb}$ of $\mathrm{H}_{2} \mathrm{~S}$ was required to treat each pound of soil, radius of influence was $20 \mathrm{ft}$, and wellinstallation and -drilling costs were $\$ 133 / \mathrm{ft}$. The sensitivity analysis indicated, in general, that in situ gas treatment should be more cost effective than excavation when $0.001 \mathrm{lb}$ of $\mathrm{H}_{2} \mathrm{~S}$ or less will reduce the $\mathrm{Cr}(\mathrm{VI})$ in a pound of soil, radius of influence is $>10 \mathrm{ft}$, and well-installation costs are $<\$ 1,000 / \mathrm{ft}$. The estimated cost can vary considerably, depending on the specific inputs, however, so it is recommended that the user perform the analysis for the combination of model inputs associated with a particular site. 


\subsection{Conclusions and Future Work}

The demonstration of the IGRS approach conducted at SWMU 143 on the White Sands Missile Range has provided information needed to complete a technical performance assessment and cost analysis of the technology. At least $70 \%$ of the Cr(VI) present in contaminated sediment at the site was reduced, thus verifying the effectiveness of the approach. Most of the treatment occurred in a zone located from $\sim 4$ to $10 \mathrm{ft}$ below ground surface, which appears to be a higher permeability interval. A deeper zone from $\sim 10$ to $16 \mathrm{ft}$ that contains lower levels of contamination was essentially unaffected. The deeper zone is somewhat finer grained and has a higher clay content and is, thus, less permeable. It appears that most of the treatment gas was channeled through the higher, more-permeable zone and the lower zone was bypassed. Treatment of the lower zone could probably be accomplished, however, if a second injection well were installed and screened across the zone so that treatment gas could be forced into this interval.

The amount of $\mathrm{H}_{2} \mathrm{~S}$ consumed during the test exceeded the amount predicted by the laboratory treatability study. In addition, the levels of $\mathrm{H}_{2} \mathrm{~S}$ observed at the extraction wells were relatively low, even though a significant level of treatment was observed at the site. It is inferred that interfering reactions or slower reaction kinetics are the likely source of consumption of extra $\mathrm{H}_{2} \mathrm{~S}$ observed in the field. Future laboratory work will be undertaken to investigate the nature of these chemical reactions and the reaction rates associated with the gaseous reduction of $\mathrm{Cr}(\mathrm{VI})$ in soils. Elucidation of these effects may reveal methods for improving the effectiveness of the technology and reducing unit costs.

A life-cycle cost model was developed for the technology based on demonstration information (Hogan 1998). This model suggests that the technology should compare favorably with excavation from a cost basis for larger sites, especially when depths exceed 15 or $20 \mathrm{ft}$. Site-specific information should be provided as input to the model to evaluate this, however, because costs vary significantly, depending on site characteristics.

The IGRS approach is considered ready for application as a remediation tool based on the success of the field demonstration at the White Sands Missile Range. It is expected that a large-scale test or deployment will take place at a U.S. Department of Energy $\mathrm{CrO}_{4}{ }^{2-}$-contaminated site within the next several years. In addition, further laboratory-testing activities are planned to identify other metal and radionuclide contaminants that can be immobilized through the gaseous reduction approach. 


\subsection{References}

40 CFR 261. US Environmental Protection Agency. "Identification and Listing of Hazardous Waste, Appendix VIII-Hazardous Constituents." US Code of Federal Regulations.

Basabilvazo GT, RG Myers, and EL Nickerson. 1994. Geohydrology of the High Energy Laser System Test Facility Site, White Sands Missile Range, Tularosa Basin, South-Central New Mexico. WaterResources Investigations Report 93-4192, U.S. Geological Survey, Albuquerque, New Mexico.

Hogan M. 1998. In Situ Gaseous Reduction Life-Cycle Cost Model. MSE Technology Applications, Butte, Montana.

Johnson PC, CC Stanley, MW Kemblowski, DL Byers, and JD Colthart. 1990. "A Practical Approach to the Design, Operation, and Monitoring of In Situ Soil-Venting Systems." Ground Water Monitoring Review 10:159-178.

Kelly TE, and GA Hearne. 1976. The Effects of Ground-Water Development on the Water Supply in the Post Headquarters Area, White Sands Missile Range, New Mexico. Open-File Report 76-277, U.S. Geological Survey, Albuquerque, New Mexico.

Larkin KA. 1995. ATP for the Prototype Gas Treatment System. WHC-SD-TD-ATP-002, Westinghouse Hanford Company, Richland, Washington.

MEVATEC. 1997. White Sands Missile Range SWMU Groundwater Monitoring Program. 300SS/97/002D, MEVATEC Corporation, White Sands Missile Range, New Mexico.

Pacific Northwest Laboratory (PNL). 1993. Procedures for Groundwater Investigations. PNL-MA-567, Rev. 1, Richland, Washington.

Tetra Tech. 1997. Final Groundwater Remedial Action Plan, HELSTF SWMVs 142, 143, and 154. White Sands Missile Range, New Mexico.

Thornton EC, and JE Amonette. 1997. Gas Treatment of Cr(VI)-Contaminated Sediment Samples from the North 60's Pits of the Chemical Waste Landfill. PNNL-11634, Pacific Northwest National Laboratory, Richland, Washington.

Thornton EC, and RL Jackson. 1994. "Laboratory and Field Evaluation of the Gas Treatment Approach for In-Situ Remediation of Chromate-Contaminated Soils." In In-Situ Remediation: Scientific Basis for Current and Future Technologies, eds. GW Gee and NR Wing, pp. 949-963. Thirty-Third Hanford Symposium on Health and the Environment, Pasco, Washington, Battelle Press, Columbus, Ohio.

Thornton EC, and RD Miller. 1996. In Situ Gas Treatment Technology Demonstration Test Plan. WHC-SD-EN-TP-055, Westinghouse Hanford Company, Richland, Washington. 
U.S. Environmental Protection Agency (EPA). 1992. Test Methods for Evaluating Solid Wastes: Physical/Chemical Methods, $3^{\text {rd }}$ ed. SW-846, Office of Solid Waste and Emergency Response, Washington, D.C.

Westinghouse Hanford Company (WHC). 1990. Geotechnical Engineering Procedure Manual. WHC-IP-0635, Richland, Washington. 


\section{Distribution}

No. of

Copies

OFFSITE

2 DOE/Office of Scientific and Technical Information

2 U.S. Department of Energy

Albuquerque, NM 87185

ATTN: D. Denham

D. G. Krivitzky

3 Sandia National Laboratories

P.O. Box 5800

Albuquerque, NM 87185

ATTN: G. C. Allen

D. C. Marozas

J. M. Phelan

5 U.S. Department of Energy

Savannah River Operations Office

P.O. Box A

Aiken, SC 29802

ATTN: S. R. McMullin

T. Hicks (3)

J. A. Wright

2 P. Solano

Hazardous \& Radioactive Materials Bureau

New Mexico Environment Department

2044 Galisteo St.

Sante Fe, NM 87505

L. Brown

Environmental \& Safety Office, HELSTF

White Sands Missile Range, NM 88002
No. of

Copies

12 J. T. Giblin

MEVATEC Corp.

Building 126, $3^{\text {rd }}$ Floor

White Sands Missile Range, NM 88002

3 H. Magallanes

Building 163

White Sands Missile Range, NM 88002

J. A. Harris (6PD-N)

EPA Region 6 Main Office

1445 Ross Avenue

Suite 1200

Dallas, TX 75202-2733

B. Deng

Department of Mineral \& Environmental Engineering

New Mexico Tech

Socorro, NM 87801

D. Huston

Oregon Office of Energy

Nuclear Safety Division

625 Marion St. NE. Suite 1

Salem, OR 97301-3742

\section{ONSITE}

7 DOE Richland Operations Office

D. L. Biancasino

$\mathrm{K} 8-50$

G. I. Goldberg

$\mathrm{H} 0-12$

R. D. Miller (3)

$\mathrm{H} 0-12$

K. M. Thompson

H0-12

D. E. Trader

Distr.1 
No. of

Copies

3 Washington Department of Ecology

W. W. Soper

N. H. Uziemblo

J. W. Yokel

2 Bechtel Hanford, Inc.

J. G. April

F. M. Corpuz

BWHC

K. A. Larkin

T5-55

CHI

M. H. Sturges

$\mathrm{X} 3-40$

COGEMA

M. J. Duchsherer

B5-18

B5-18

B5-18
No. of

Copies

58 Pacific Northwest National Laboratory

C. C. Ainsworth

$\mathrm{K} 3-61$

J. E. Amonette

K8-96

W. F. Bonner

K9-14

T. M. Brouns

K9-91

J. G. Bush

K6-96

R. J. Cameron

$\mathrm{K} 6-24$

K. J. Cantrell

K6-81

J. L. Devary

K6-96

R. M. Ecker

K6-91

M. W. Fullmer

K3-66

J. S. Fruchter

K6-96

T. J Gilmore (5)

K6-81

H. Hampt

K6-96

J. L. Julya

K6-75

G. V. Last

K6-81

W. J. Martin

K3-54

A. V. Mitroshkov K6-96

L. F. Morasch

K6-86

K. B. Olsen

K6-96

M. E. Peterson

K9-04

R. Schalla

K6-96

F. A. Spane

K6-96

J. E. Szecsody

K3-61

E. C. Thornton (24)

K6-96

Information Release Office (7) 